\title{
LiDAR, GIS, and multivariate statistical analysis to assess landslide risk, Horseshoe Run watershed, West Virginia
}

Kory M. Konsoer

West Virginia University

Follow this and additional works at: https://researchrepository.wvu.edu/etd

\section{Recommended Citation}

Konsoer, Kory M., "LiDAR, GIS, and multivariate statistical analysis to assess landslide risk, Horseshoe Run watershed, West Virginia" (2008). Graduate Theses, Dissertations, and Problem Reports. 4392. https://researchrepository.wvu.edu/etd/4392

This Thesis is protected by copyright and/or related rights. It has been brought to you by the The Research Repository @ WVU with permission from the rights-holder(s). You are free to use this Thesis in any way that is permitted by the copyright and related rights legislation that applies to your use. For other uses you must obtain permission from the rights-holder(s) directly, unless additional rights are indicated by a Creative Commons license in the record and/ or on the work itself. This Thesis has been accepted for inclusion in WVU Graduate Theses, Dissertations, and Problem Reports collection by an authorized administrator of The Research Repository @ WVU. For more information, please contact researchrepository@mail.wvu.edu. 


\title{
LiDAR, GIS, and Multivariate Statistical Analysis to Assess Landslide Risk, Horseshoe Run Watershed, West Virginia
}

\author{
Kory M. Konsoer \\ Thesis Submitted to the Eberly College of \\ Arts and Sciences at West Virginia \\ University In Partial Fulfillment of the \\ Requirements for the Degree of
}

Master of Science in Geology

J. Steven Kite, Chair, Ph.D

Robert Behling, Ph.D

Michael Strager, Ph.D

Department of Geology and Geography

Morgantown, West Virginia

2008

Keywords: landslides, LiDAR, GIS, landslide susceptibility, surficial mapping 


\title{
$\underline{\text { Abstract: }}$ \\ LiDAR, GIS, and Multivariate Statistical Analysis to Assess Landslide Risk, Horseshoe Run Watershed, West Virginia
}

\author{
Kory M. Konsoer \\ Current stream restoration practices focus on stabilizing banks, transporting \\ sediment, and creating aquatic habitats. However, only channel morphology data are \\ collected prior to typical restoration project designs. A more thorough approach to \\ assessing restoration projects incorporates the geomorphology of the contributing \\ hillslopes within the watershed. For this project, a landslide risk assessment was \\ conducted for Horseshoe Run watershed in West Virginia using LiDAR data, GIS, and \\ multivariate statistical analysis to provide the restoration projects with information \\ concerning the geomorphology of the hillslopes and identify areas of greater risk for \\ slope failure. A landslide inventory map was created using field observations and remote \\ mapping on a LiDAR-derived shaded relief map within ArcGIS 9.2. Landslides were \\ classified as planar slides, rotational slumps, debris flows, debris fans, debris slides, or \\ active slopes. Seven variables were determined for all landslides: elevation, slope angle, \\ slope aspect, distance from roads, distance from streams, plan curvature, and profile \\ curvature. Similar data on the same seven variables also were collected for a random \\ sample of unfailed slopes, and both data sets were used for discriminant analyses using \\ Minitab 13.30. A first discriminant analysis of all failed and unfailed slopes was $71.8 \%$ \\ accurate in predicting failures and non-failed slopes, suggesting a significant difference \\ between the two populations. A second discriminant analysis was $76.3 \%$ accurate in \\ determining differences between classifications of slope movements. The discriminant \\ analyses results were used to create a landslide susceptibility map for Horseshoe Run \\ watershed, classifying the hillslopes as low, medium, or high risk for failure. Areas \\ classified as high risk areas were further analyzed to determine whether they were \\ contributing to the channel instability of Horseshoe Run. The landslide susceptibility map \\ also provided a means to evaluate locations of concern for slope stability and also \\ identify potential areas of disturbance for Horseshoe Run.
}




\section{Acknowledgements:}

I would first like to thank Dr. Steven Kite for his help and guidance through the entirety of this project by offering both invaluable comments and many hours in the field. I would also like to thank my other committee members, Dr. Behling and Dr. Strager, for their comments and insight. I would also like to acknowledge Dr. Joe Donovan and Dr. Strager for their assistance with the statistics of this project.

Deep appreciation and thanks is also given to the USGS EDMAP program for providing summer funding for this project. Additionally, I would like to thank the Canaan Valley Institute for allowing the use of their LiDAR data and always being available for questions. The LiDAR data was the main foundation of this project.

Thanks are also given to my classmate Beau Downing for his help with mapping and providing comments on my thesis. Also, I would like to thank Keri Wilson, David Bennnet, and Mark VanDyke for their assistance in the field and in the computer lab digitizing the surficial geology map.

Lastly, I would like to thank my family for their never-ending support and love. Their caring and friendship helped guide me through the difficult times and lead me to the finish. I would especially like to thank my fiancée Samantha Hawkins for her overwhelming support and motivation. 


\section{Table of Contents}

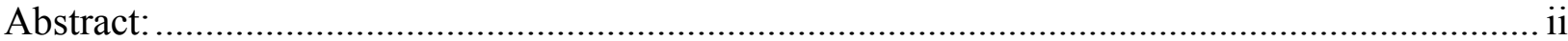

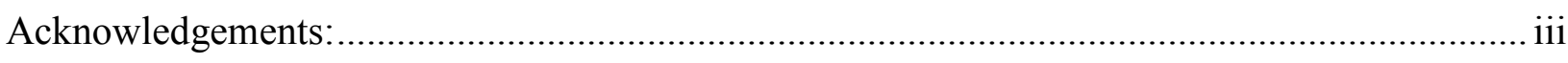

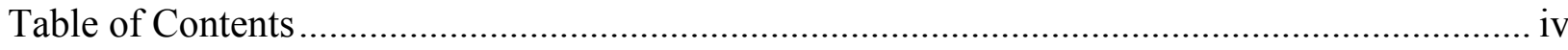

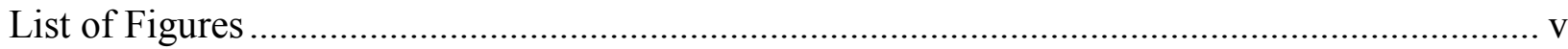

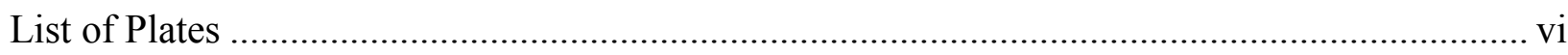

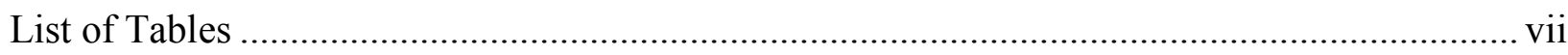

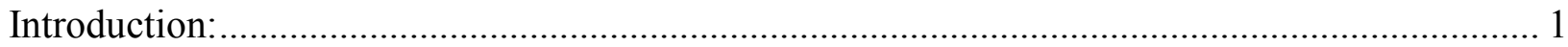

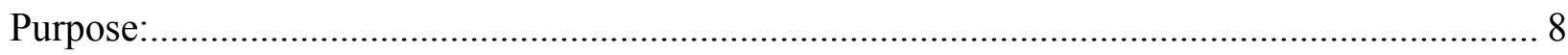

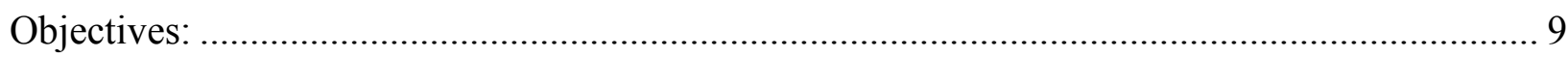

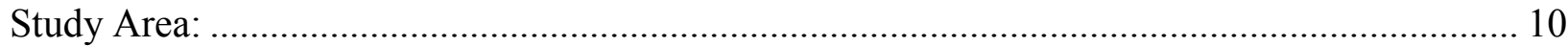

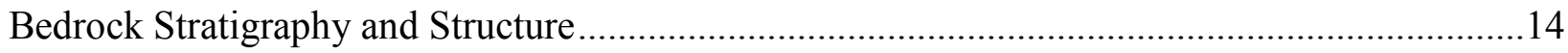

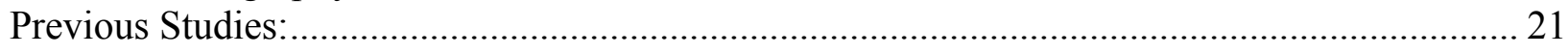

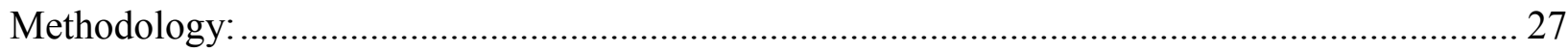

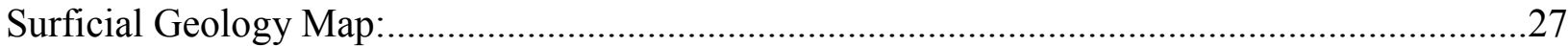

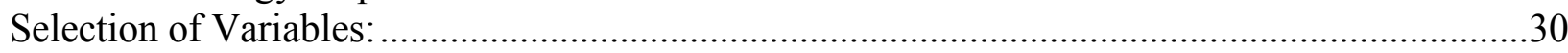

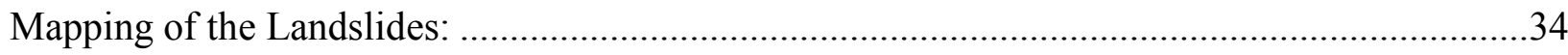

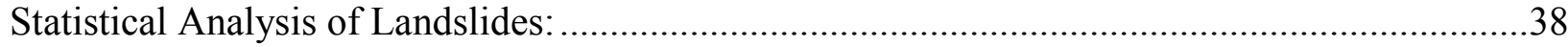

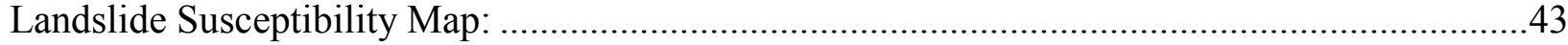

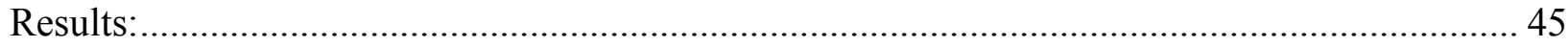

Surficial Geology Map of Horseshoe Run watershed: ..........................................................45

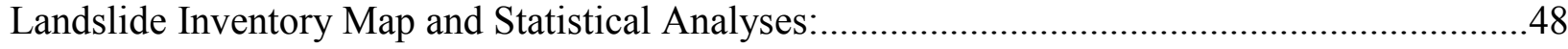

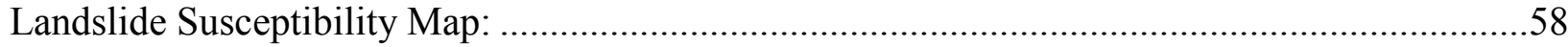

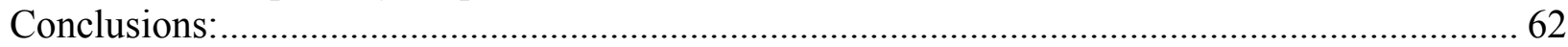

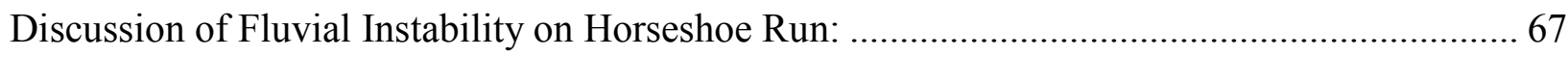

Discussion of the Landslide Susceptibility Map:............................................................. 73

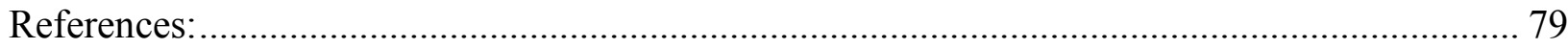

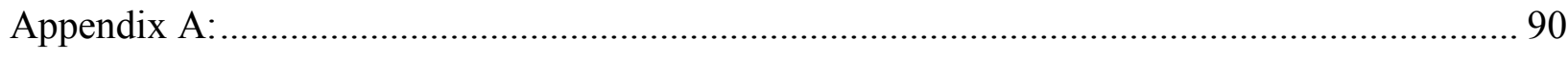

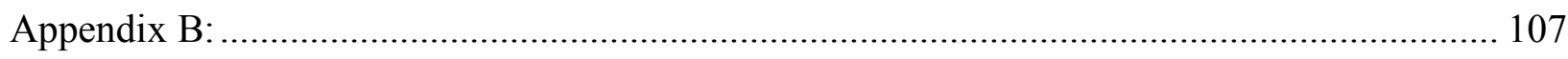

Appendix C:

Appendix D:

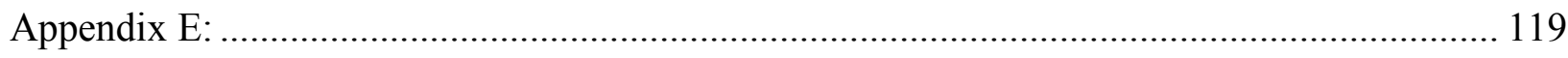

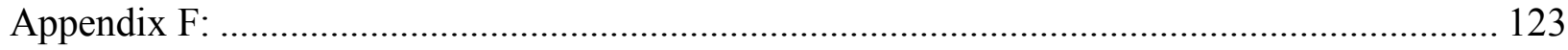




\section{List of Figures}

Figure 1: Location map of Horseshoe Run watershed.............................................. 3

Figure 2: Tributary showing evidence of slope movements forcing stream response........ 5 Figure 3: Photograph of Horseshoe Run watershed showing steep terrain and heavy

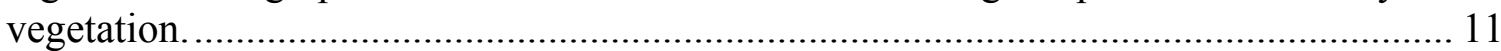

Figure 4: Photograph of Horseshoe Run watershed showing steep topography. ............ 12 Figure 5: Location map of Horseshoe Run watershed in relation to the Cheat River basin.

Figure 6: Geologic map of Horseshoe Run watershed. ............................................. 15

Figure 7: Geologic cross-section of Horseshoe Run watershed.. ................................... 16

Figure 8: Photograph of a coarse grained alluvial terrace within Horseshoe Run

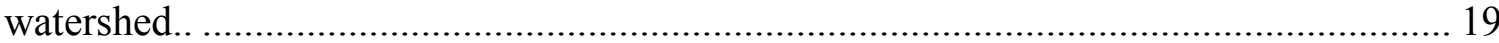

Figure 9 Coarse, subangular to subrounded cobbles in a debris flow deposit in Horseshoe

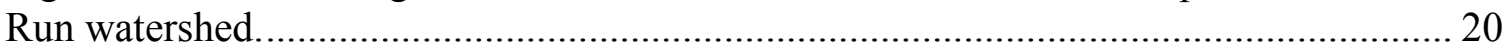

Figure 10: Bouldery gelifluction lobes on Backbone Mountain..................................... 29

Figure 11: LiDAR-derived shaded relief map image showing an example of a debris fan..

Figure 12: LiDAR-derived shaded relief map showing an example of a debris flow..... 36

Figure 13: LiDAR-derived shaded relief map showing an example of a debris slide...... 37

Figure 14: LiDAR-derived shaded relief map showing an example of a planar slide...... 39

Figure 15: LiDAR-derived shaded relief map showing an example of a rotational slump..

Figure 16: LiDAR-derived shaded relief map showing an example of an active slope.. . 41

Figure 17: Large boulder field on Backbone Mountain, Horseshoe Run watershed........ 47

Figure 18: Summary of discriminant analysis of failed versus unfailed slopes within

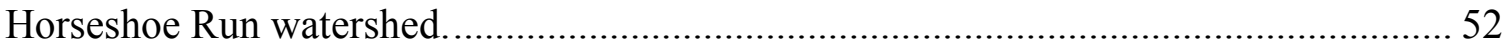

Figure 19: Summary of discriminant analysis of the classification of slope movements including unfailed slopes.

Figure 20: Summary of discriminant analysis of the different classifications of failed

slopes within Horseshoe Run watershed............................................................... 54

Figure 21: Rose diagrams showing the preferred aspects for planar slides and rotational slumps within Horseshoe Run watershed. .................................................................... 55

Figure 22: Rose diagram showing the preferred slope aspects for debris flows and debris

fans within Horseshoe Run watershed........................................................................ 56

Figure 23: Rose diagrams showing the differences in aspect of debris fans and unfailed

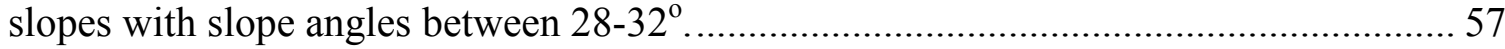

Figure 24: Landslide susceptibility map showing the confluence of Wolf Run and Horseshoe Run and the relative sizes of both drainage basins. ................................... 77

Figure 25: Landslide susceptibility map showing the location of Maxwell Run and its confluence with Horseshoe Run.. 


\section{List of Plates}

Plate 1: Surficial Geology Map of Horseshoe Run watershed, Tucker and Preston

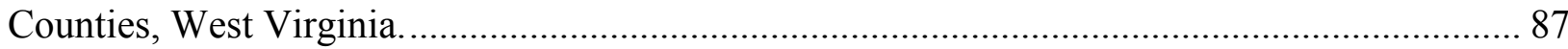

Plate 2: Landslide Inventory Map for Horseshoe Run watershed ............................................... 88

Plate 3: Landslide susceptibility map of Horseshoe Run watershed. ............................................. 89 


\section{$\underline{\text { List of Tables }}$}

Table 1: Stratigraphic Units in Horseshoe Run watershed (from Reger, 1923).

Table 2: Classifications of surficial geology features and the characteristics used to remotely map them within Horseshoe Run watershed.

Table 3: Number of different types of slope movements mapped within Horseshoe Run watershed.

Table 4: Mean values of landscape variables used in the landslide analyses for the different types of slope movements.

Table 5: Landslide susceptibility risk and the percentage of area within Horseshoe Run. 


\section{Introduction:}

Geologic hazards, such as landslides, are a serious threat to both life and property. In the United States alone, it is estimated that landslide hazards cause between $\$ 1-2$ billion in damages and average more than 25 deaths per year (U.S. Geological Survey, Landslide Hazards Program). The state of West Virginia is especially vulnerable to masswasting events given its steep topography in the Appalachian Mountains, and the effects of decades of logging and mining. Understanding which factors contribute to slope failures are therefore invaluable in the monitoring, prediction, and mitigation of masswasting events.

Mass-wasting events also can have an effect on the natural landscape by modifying the morphology of streams and altering local biologic populations. These two concepts have been linked together by the river continuum concept (Vannote, 1980), which states that the dynamic geomorphologic processes occurring at the reach scale help to define specific habitats in which certain organisms prefer. Therefore, altering the stream morphology can be devastating to local stream ecology. Additionally, numerous studies have shown that an accumulation of fine sediment, often introduced by masswasting events or anthropogenic alterations, can have a significant impact on benthic, insect, and fish populations (Kaller and Hartman, 2004; Kreutzweiser et al., 2005; Rabeni et al., 2005; Cordone and Kelley, 1961; Cederholm et al., 1980).

Relationships between hillslope failures and fluvial adjustments have also been intensely studied (Harvey, 2001; Downs and Gregory, 1998; Michaelides and Wainwright, 2002). Many different morphologic responses as a result of landslides have been observed and documented. Debris flows are extremely erosive and have been shown 
to scour low order tributaries to bedrock and remove stored sediment from terraces (Cenderelli and Kite, 1998). Debris flows have also been shown to cause damming of stream channels in lower order tributaries in mountain basins (Hoffman and Gabet, 2002). These debris flow dams cause deposition of fine grained sediment upstream and cause braiding downstream due to increases in sediment load. By modifying the channel morphology and sediment transportation, alterations in the stream hydrograph can occur, which may increase the potential risk of flooding for a given segment of the stream.

Through stream restoration, and more specifically natural stream channel design, the negative effects caused by natural and anthropogenic disturbances can be mitigated and often corrected. By diverting flow to the thalweg of the channel, revegetating riparian areas, restoring water quality, and adding habitat structures, biologic communities can proliferate, stream bank erosion can be minimized, and sediment transportation rates can be adjusted. Growing concerns for our national waterways has lead to an increase in the number of stream restoration projects within the past decade. Restoration projects can be seen on large rivers, such as the Mississippi (Theiling, 2006), which affects millions of people, to smaller low-order tributaries that are of great importance to the sustainability of fish and other biologic populations (Muotka et al., 2002).

Horseshoe Run watershed is located in Tucker and Preston counties, West Virginia. The stream is approximately $27.23 \mathrm{~km}$ in length and drains an area of about $143.7 \mathrm{~km}^{2}\left(55.5 \mathrm{mi}^{2}\right)$ (Figure 1). Time-series aerial photography has shown that for at least 100 years, Horseshoe Run has migrated widely across its floodplain, transporting large amounts of coarse alluvium. The primary source of the alluvium is believed to be from bank erosion (Greene, 2008) and may also be introduced by local hillslope 


\section{Horseshoe Run Watershed, West Virginia}

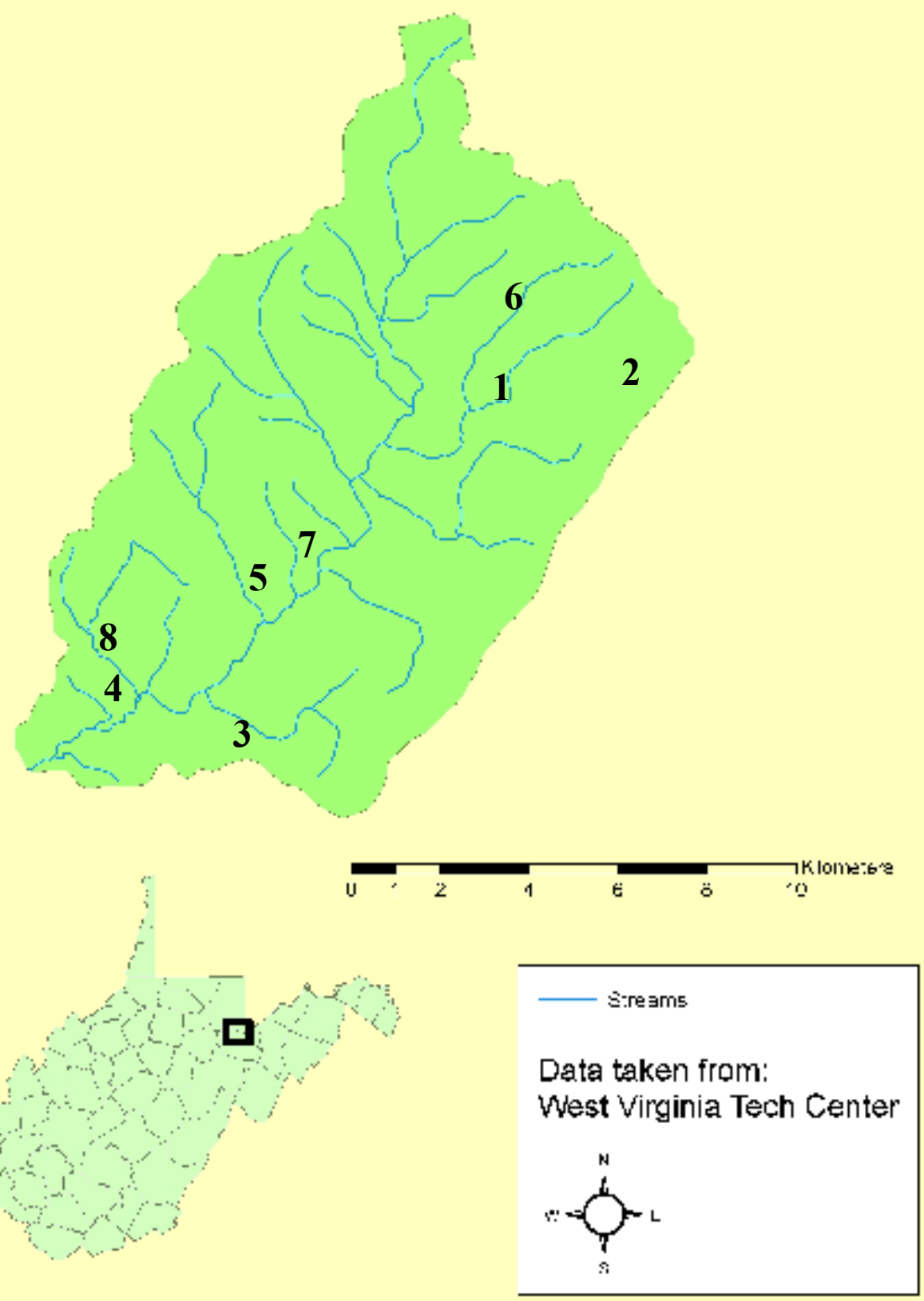

Figure 1: Location map of Horseshoe Run watershed. Numbers on map indicate the locations of the examples of surficial features shown in subsequent figures. 
processes, mostly landslides and debris flows. This instability has prompted local residents and the Canaan Valley Institute (CVI) to begin implementing natural channel design restoration projects to increase the stability of the channel banks and increase alluvial sediment transportation efficiency in selected reaches.

Exact causes for the excessive sediment supply within Horseshoe Run watershed are unknown; however, one proposed explanation is intense logging around A.D. 1900 (Reger, 1923), which increased runoff and colluvial processes. Whatever the cause of the increased sediment supply, there is a direct relationship between large amounts of colluvial sediments and the instability of stream channels (Korup, 2005; Cenderelli and Kite, 1997). Direct observations within the watershed reveal hillslope sediment is forcing stream response (Figure 2).

Stream restoration techniques have recently focused on increasing channel stability, sediment transport potential, water quality, and habitat rehabilitation. Prior to the implementation of a restoration project, it is common practice to complete an analysis of the current conditions and determine long term goals for each restoration project (Canaan Valley Institute, 2007). In the context of Horseshoe Run, CVI conducted numerous assessments, such as morphological stream assessment, bankfull determination, regional curve validation, and sediment transport assessment and prediction (Canaan Valley Institute, 2007). These assessments were carried out for the lower $6.1 \mathrm{~km}(3.8 \mathrm{mi})$ of the stream, and it was determined that heavy sediment loads from upstream, in-channel sources were the primary causes of channel instability (Canaan Valley Institute, 2007). 


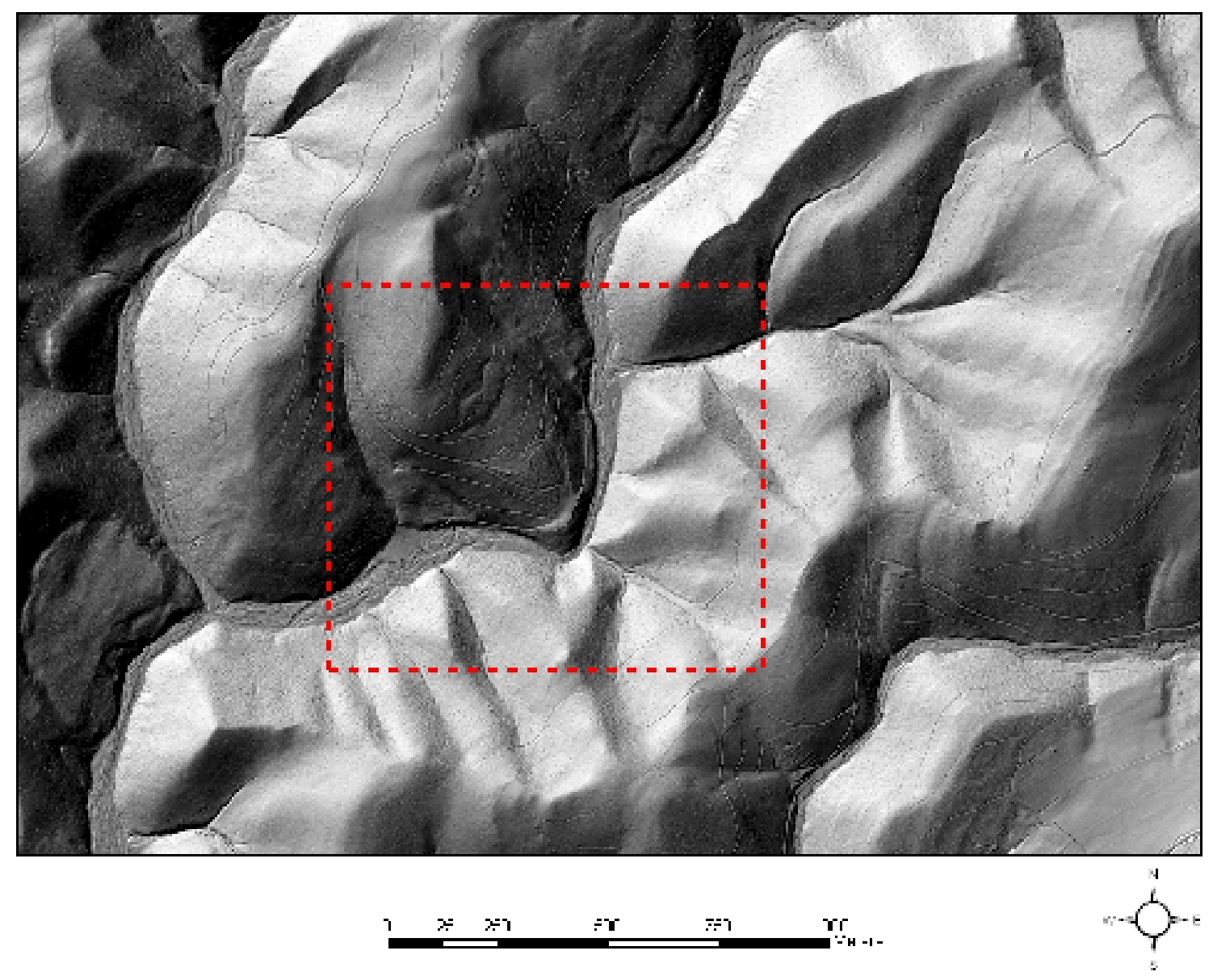

Figure 2: Tributary showing evidence of slope movements forcing stream response. Location of landslide number 1 shown on Figure 1. 
In order to create a fully successful natural channel design restoration project, it is vital to incorporate information for the entire watershed. However, no assessment of the hillslope geomorphology within the watershed was performed before natural channel design techniques were applied. Ignoring, or overlooking, geomorphological hillslope processes within the watershed could leave restoration techniques as futile attempts, or even worse, have a detrimental effect of the watershed as a whole.

Most commonly, slope movements initiate as a result of either brief, high intensity rainfall or prolonged seasonal snowfall and rainfall that provide large amounts of soil moisture. In either case, certain slope conditions prior to rainfall are necessary conditions for slope failure to occur in response to a triggering precipitation event. Variables that describe these conditions include slope angle, slope aspect, vegetation cover, underlying bedrock lithology, geologic structure, soil texture and thickness, soil mineralogy, geohydrology, and proximity to streams and anthropogenic alterations, Slope failures typically result from a combination of these factors; as well as other possible factors.

Many different methods have been used to study and map landslides, such as inventory maps, susceptibility maps, and predictive maps (Van Den Eeckhaut et al., 2007; Wieczorek et al., 2006; Duman et al., 2005; McKean and Roering, 2004). Inventory maps show the location and spatial distribution of previously failed slopes in a given area. Although these types of maps are an important first step in studying landslides, they provide no further information to protect against future landslide events. Susceptibility maps, on the other hand, provide information to assist in landslide prediction. Susceptibility maps are based on general knowledge of how slope failures 
occur; for example, designating areas with steeper slopes as higher risk areas. Landslide susceptibility maps show a qualitative likelihood of failure for given areas, and usually categorize slopes as having low, medium, or high risk. While susceptibility maps provide more information than inventory maps, the use of susceptibility maps in preventative management is limited. Predictive landslide maps, however, are more useful for management decisions because they incorporate a probability of slope failure based on dates of previously failed slopes. Information about the frequency of slope failures, along with data collected on specific variables known to increase slope risk, result in an objective landslide predictive map.

Regardless of which type of landslide map is being created, the use of a geographic information system (GIS) is extremely valuable. GIS allows for easy manipulation of digital maps that can be combined to create a final digital output map, presenting those areas at higher risk for landslides, and allows easy updates and corrections that may arise due to new information. The use of GIS is also important when dealing with large study areas that may have limited access, or are difficult to traverse, which is the case for Horseshoe Run watershed. In such cases, the use of remote sensing data, such as Light Detection and Ranging (LiDAR), is invaluable because it optimizes time spent in the field and allows for mapping surficial features that would otherwise be unseen. 


\section{Purpose:}

The primary working hypothesis for this project is that slope movements are a factor contributing to the channel instability of Horseshoe Run. Consequently, in order to test this hypothesis, a detailed slope analysis is required in order to determine which slope failure factors are the most important within Horseshoe Run watershed and to assess risk at landslide prone sites. Landslide susceptibility was determined by creating a surficial geology map for Horseshoe Run watershed to show the spatial distribution of landforms and deposits. From the surficial map, a landslide inventory map was formed. GIS was used to collect data from each slope movement using seven different LiDARderived variables: slope angle, slope aspect, elevation, plan curvature, profile curvature, distance from roads, and distance from streams. The data collected were then tested for correlation between variables and used in a discriminant analysis to determine which factors are most important to slope failure. 


\section{Objectives:}

An in-depth understanding of the geomorphology of Horseshoe Run watershed is necessary in order to understand sediment transport controls that directly impact restoration efforts. Landslides can affect stream channels not only by direct forcing of channel changes, but also indirectly through legacy sediments stored in the system. Examining the entire watershed, both channels and hillslopes, allows for integrated restoration and management, and will result in the highest level of success.

The objectives of this study are, therefore, to:

1. Create a surficial geology map of the watershed using LiDAR, GIS, and limited field work. This map will show the distribution of landforms and surficial deposits.

2. Determine if statistical thresholds exist between different classifications of slope movements.

3. Determine factors directly influencing slope stability within the watershed using the student's t-test and discriminant analysis.

4. Determine thresholds of failure for each factor, in order to select areas that have a greater risk of slope failure.

5. Create a landslide susceptibility map using advanced multivariate statistical analysis techniques and GIS.

6. Evaluate whether slope failures are a cause of significant channel instability along Horseshoe Run. 


\section{Study Area:}

Horseshoe Run watershed is located in Tucker and Preston counties, West Virginia. The stream is approximately $27.23 \mathrm{~km}$ in length and drains an area of about $143.7 \mathrm{~km}^{2}\left(55.5 \mathrm{mi}^{2}\right)$. The watershed is located in the heavily vegetated, steep terrain of the Appalachian Mountains, and $61 \%$ of the watershed is privately owned (Figure 3 and 4). The run is a tributary to the Cheat River (Figure 5). The watershed's headwaters begin

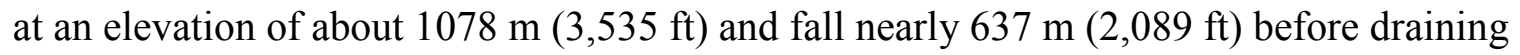
into the Cheat River. Land use in the wide valley bottom in the lower part of the watershed is primarily devoted to pasture, whereas hillslopes and ridges are mainly second- or third-growth forest (Reger, 1923).

The lumber industry has a long history in Horseshoe Run watershed and dates back as early as 1825 when the second sawmill in Tucker County was built by Arnold Bonnifield on Horseshoe Run, in the unincorporated town of Pleasant Vale (Fansler, 1962). The Pleasant Vale sawmill was in operation until 1865, and was shortly followed by another sawmill within the watershed; the Leadmine sawmill that was in operation from 1866 to 1880 (Fansler, 1962). In addition to these sawmills, logging and logging railroads also played an important role in the history of the watershed, reaching its peak with the Preston Railroad from 1892 to 1925 (Fansler, 1962). Forests were cleared within the watershed and also the nearby drainage basins. However, unlike most logging operations, the lumber that was harvested within the Cheat River basin was transported uphill to Crellin, Maryland, located just east across the state border, via the South Branch of Wolf Run, gaining roughly $200 \mathrm{~m}(656 \mathrm{ft})$ in elevation. 


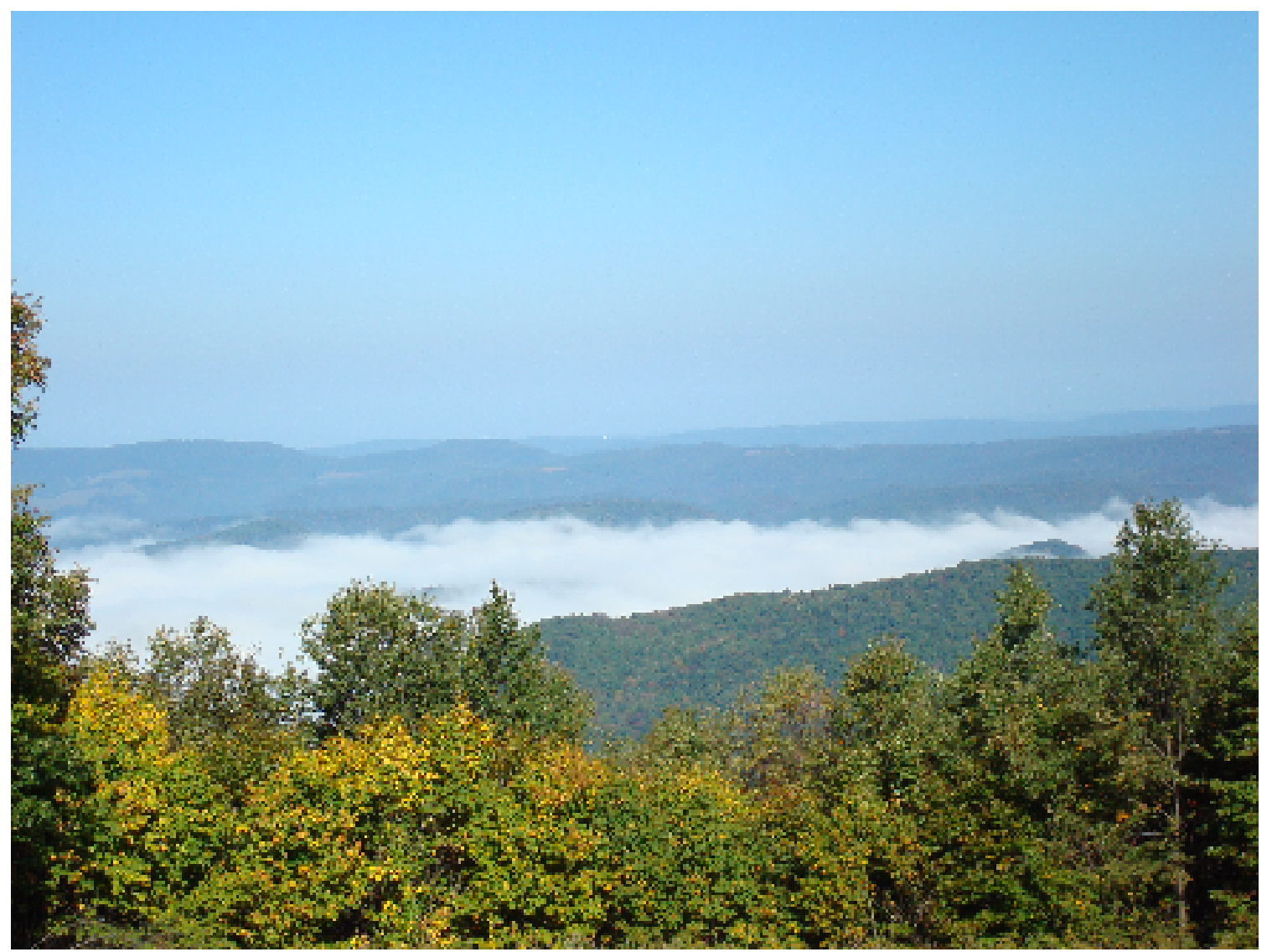

Figure 3: Photograph of Horseshoe Run watershed showing steep terrain and heavy vegetation. 


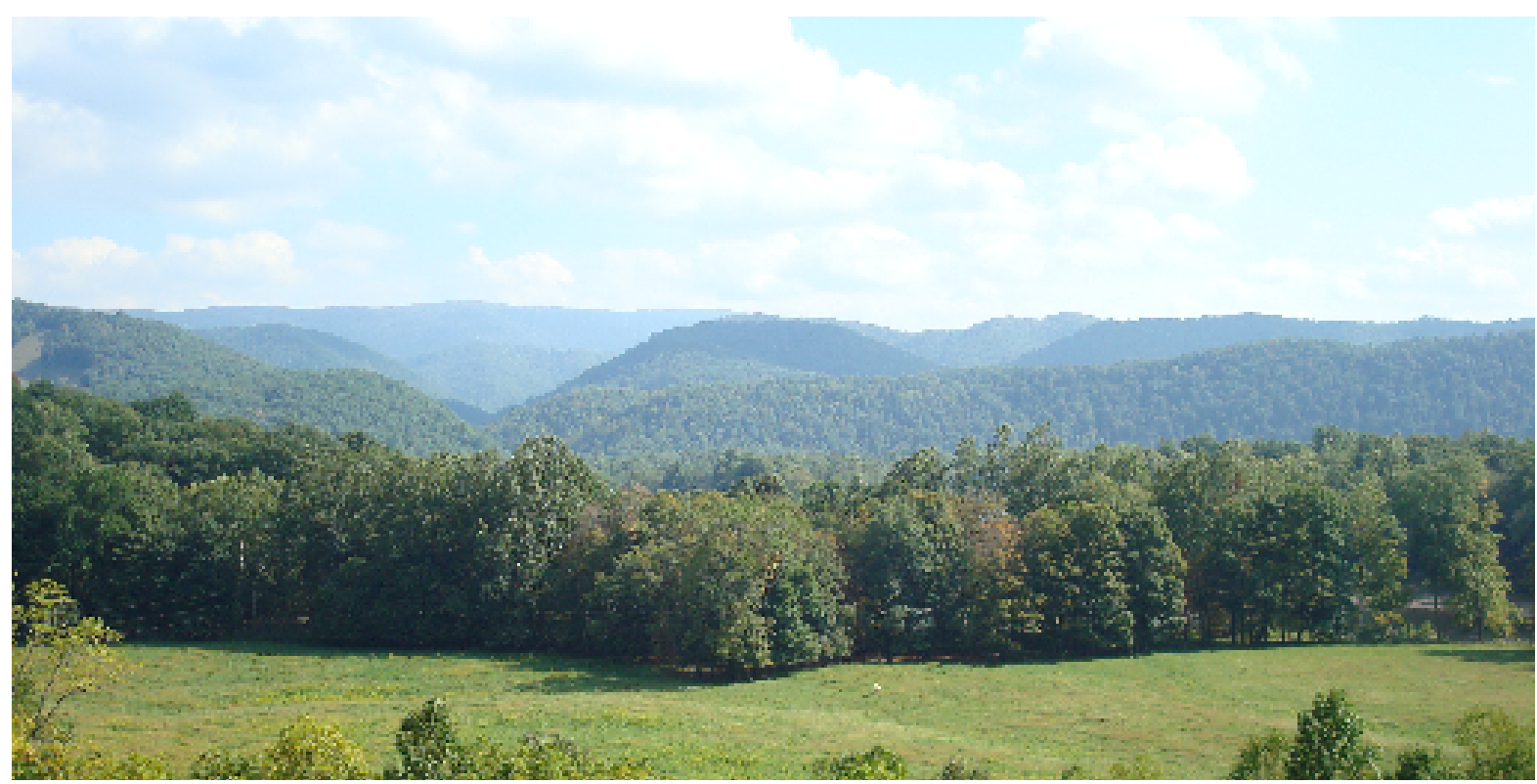

Figure 4: Photograph of Horseshoe Run watershed showing steep topography. 


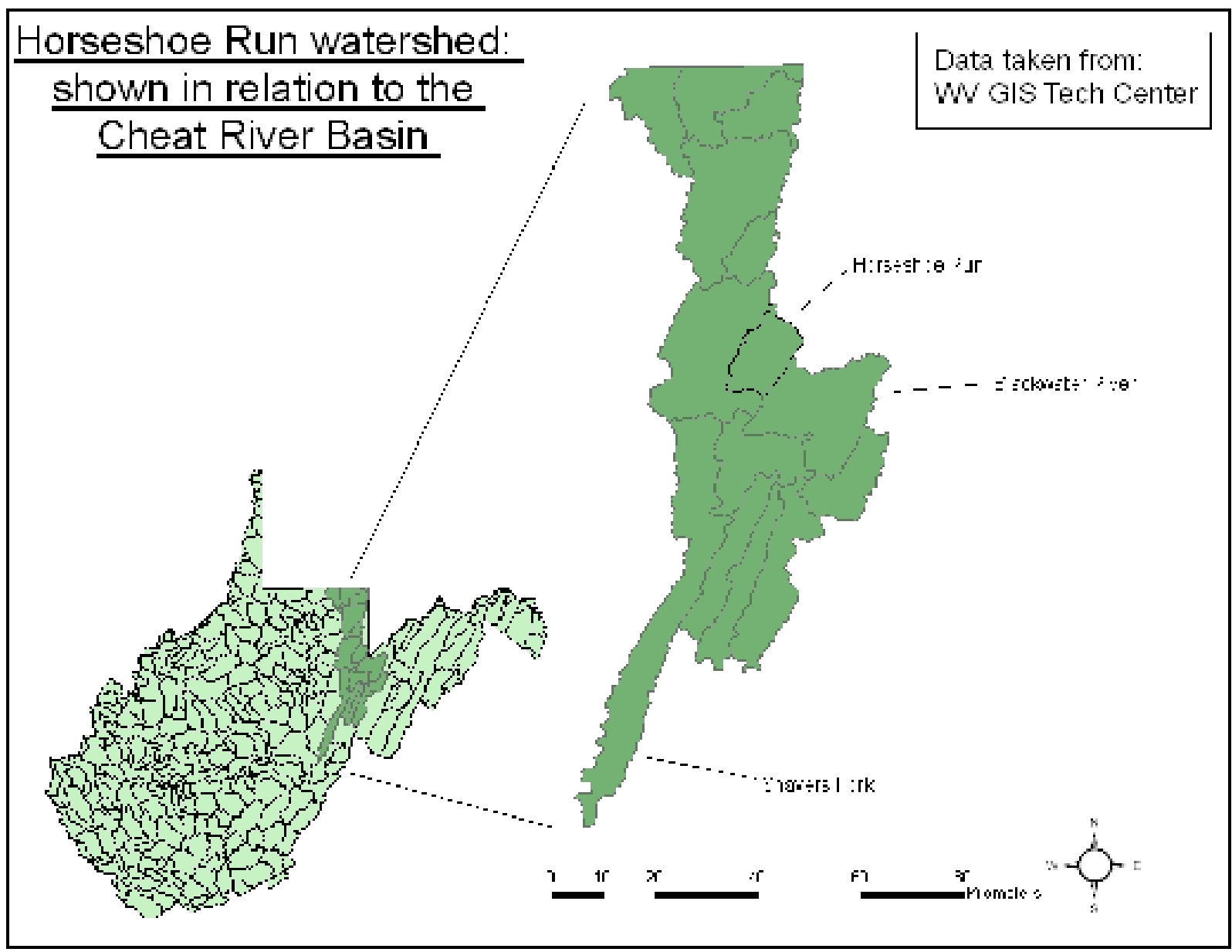

Figure 5: Location map of Horseshoe Run watershed in relation to the Cheat River basin. 


\section{Bedrock Stratigraphy and Structure}

In the southeastern part of the Horseshoe Run watershed, relatively thin units of resistant lithologies occur, forming Backbone Mountain. The capstone of this ridge is the Pennsylvanian Pottsville Sandstone. Below the Pottsville sandstone are the shaley Mississippian units of the Mauch Chunk Group, the thin Greenbrier Limestone, the resistant Pocono sandstone, and the Devonian Catskill Series, locally called the Hampshire Formation. Below the Hampshire Formation are the thick units of the Chemung Group, a thick Devonian sandy shale with interbedded sandstone units. Horseshoe Run watershed is primarily underlain by the Chemung Group, covering $82 \%$ of the area within the watershed (Figure 6). These moderately resistant Chemung rocks exhibit major folding whose fold axes are oriented roughly NE-SW. The overall structure of the watershed can be summarized by a broad, gently folded anticline with limbs dipping at about $14^{\circ} \mathrm{NW}$ and SE on the flanks of the watershed (Figure 7). The contact between the Catskill and Chemung is difficult to identify because it varies spatially and has been interpreted to be inter-tounging throughout thicknesses of hundreds of feet (Reger, 1923). Within Horseshoe Run watershed, the contact can be recognized by the presence of the Hendricks Sandstone, which marks the top of the Chemung (Reger, 1923). Table 1 summarizes the stratigraphic units' characteristics and thicknesses.

The highly resistant Pottsville Sandstone in the Backbone Mountain stratigraphic section is not responsible for the numerous hillslope movements that are observed within the watershed. The vast majority of hillslope movements occur within the sandy shale units of the Chemung Group. There are two main reasons why the hillslope movements are mainly restricted to the Chemung Group: 1) the majority of the watershed is underlain 


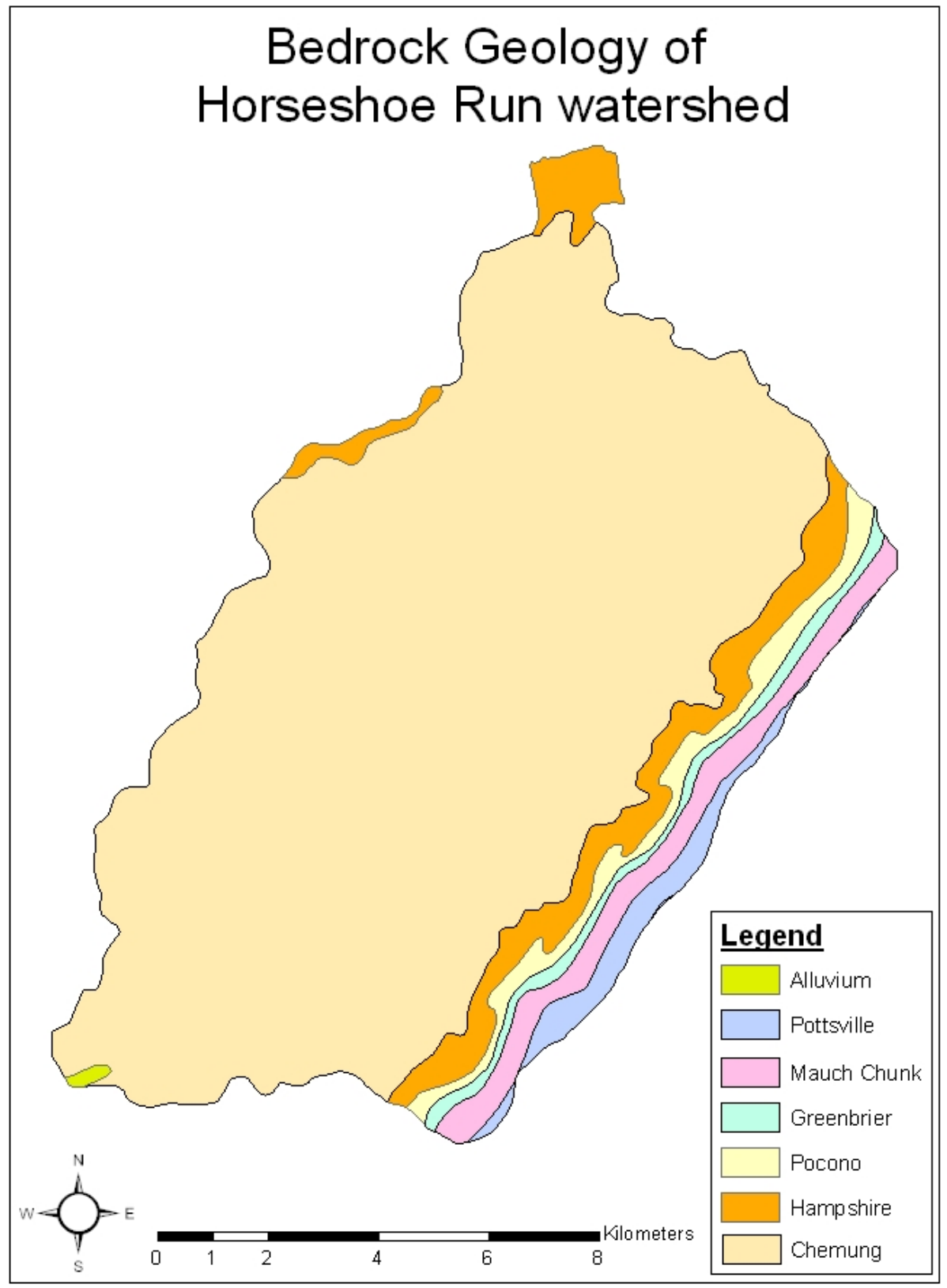

Figure 6: Geologic map of Horseshoe Run watershed. Chemung and Hampshire formations are Devonian in age; Pocono, Greenbrier, and Mauch Chunk formations are Mississippian in age; Pottsville formation is Pennsylvanian in age; Alluvium is Quaternary in age. 


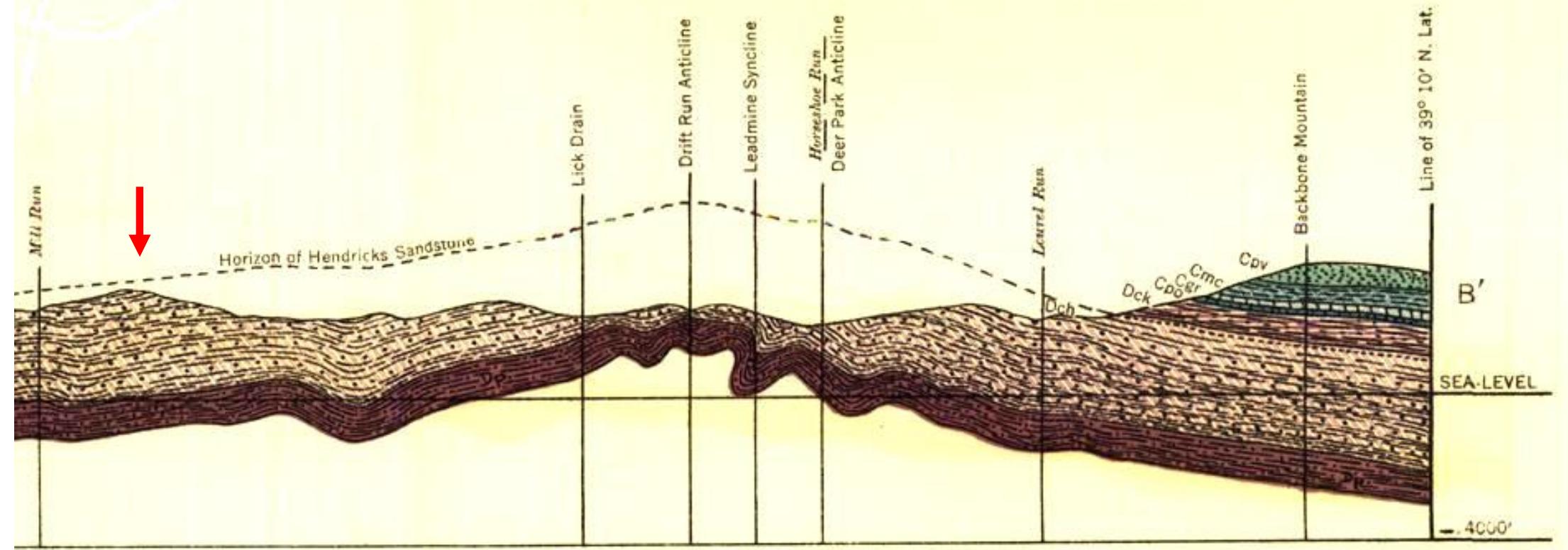

Figure 7: Geologic cross-section of Horseshoe Run watershed. . Cpv - Pottsville; Cmc - Mauch Chunk; Cgr - Greenbrier; Cpo - Pocono; Dck Catskill; Dch - Chemung. Northwestern drainage divide shown by red arrow. Backbone Mountain. is the southeastern drainage divide, and the unnamed ridge under the red arrow is the northwestern drainage divide. Figure taken from Reger, 1923. 


\begin{tabular}{|l|l|l|l|}
\hline Stratigraphic Formation & Age & Thickness (m) & Characteristics \\
\hline $\begin{array}{l}\text { Pottsville Formation } \\
\text { Upper Section -Kanawha } \\
(77 \mathrm{~m})\end{array}$ & Pensylvanian & 161 & $\begin{array}{l}\text { The upper section is mostly a continuous } \\
\text { conglomeratic sandstone, followed by } \\
\text { dark gray shales. The lower section is } \\
\text { composed of interbedded shales and } \\
\text { pebbly sandstones. Conglomerate units } \\
\text { weather into large boulders. }\end{array}$ \\
$\begin{array}{l}\text { Nower Section - } \\
\text { (83 m) })\end{array}$ & Mississippian & 178 & $\begin{array}{l}\text { Primarily massive red and greenish } \\
\text { shales with occasional lenticular, fine- } \\
\text { grained, flaggy sandstones. }\end{array}$ \\
\hline Mauch Chunk & Mississippian & 50 & $\begin{array}{l}\text { Composed on numerous beds of marine } \\
\text { limestone separated by thin beds of gray } \\
\text { shales. Crinoids and brachiopods } \\
\text { prevalent within limestone beds. }\end{array}$ \\
\hline Greenbrier Limestone & Mississippian & 38 & $\begin{array}{l}\text { At the top of this series is a cliff forming } \\
\text { pebbly conglomeratic sandstone, } \\
\text { followed by gray and brown medium- } \\
\text { grained sandstones. }\end{array}$ \\
\hline Pocono Series & Devonian & 220 & $\begin{array}{l}\text { Composed mostly of red shales and } \\
\text { red/brown fine-grained micaceous } \\
\text { sandstones. }\end{array}$ \\
\hline Catskill Series & Devonian & $\begin{array}{l}\text { Alternating deposits of olive-green shales } \\
\text { and fine-grained sandstones, varying in } \\
\text { thickness. }\end{array}$ \\
\hline Chemung & 881 &
\end{tabular}

Table 1: Stratigraphic Units in Horseshoe Run watershed (from Reger, 1923). 
by the Chemung Group and 2) the Greenbrier Limestone outcrop belt acts as a sink for colluvium originating from Mountain. In addition to these factors, because the Pottsville Formation is so resistant to erosion, the weathered products from this formation are large boulders of coarse sandstone (Hack and Goodlett, 1960).Transportation of these large Pottsville boulders tends to occur as slow creep or local rock fall. In contrast to the weathering products of the Pottsville, since most of the slope movements occur where the underlying lithologies are clastic sandy shales with thin layers of interbedded sandstone, the colluvium and alluvium tend to be composed of coarse, subangular-to-subrounded pebbles and cobbles, including poorly sorted colluvial diamictons (Figures 8 and 9). These diamictons are well exposed where the channel has eroded the toe of the deposit. 


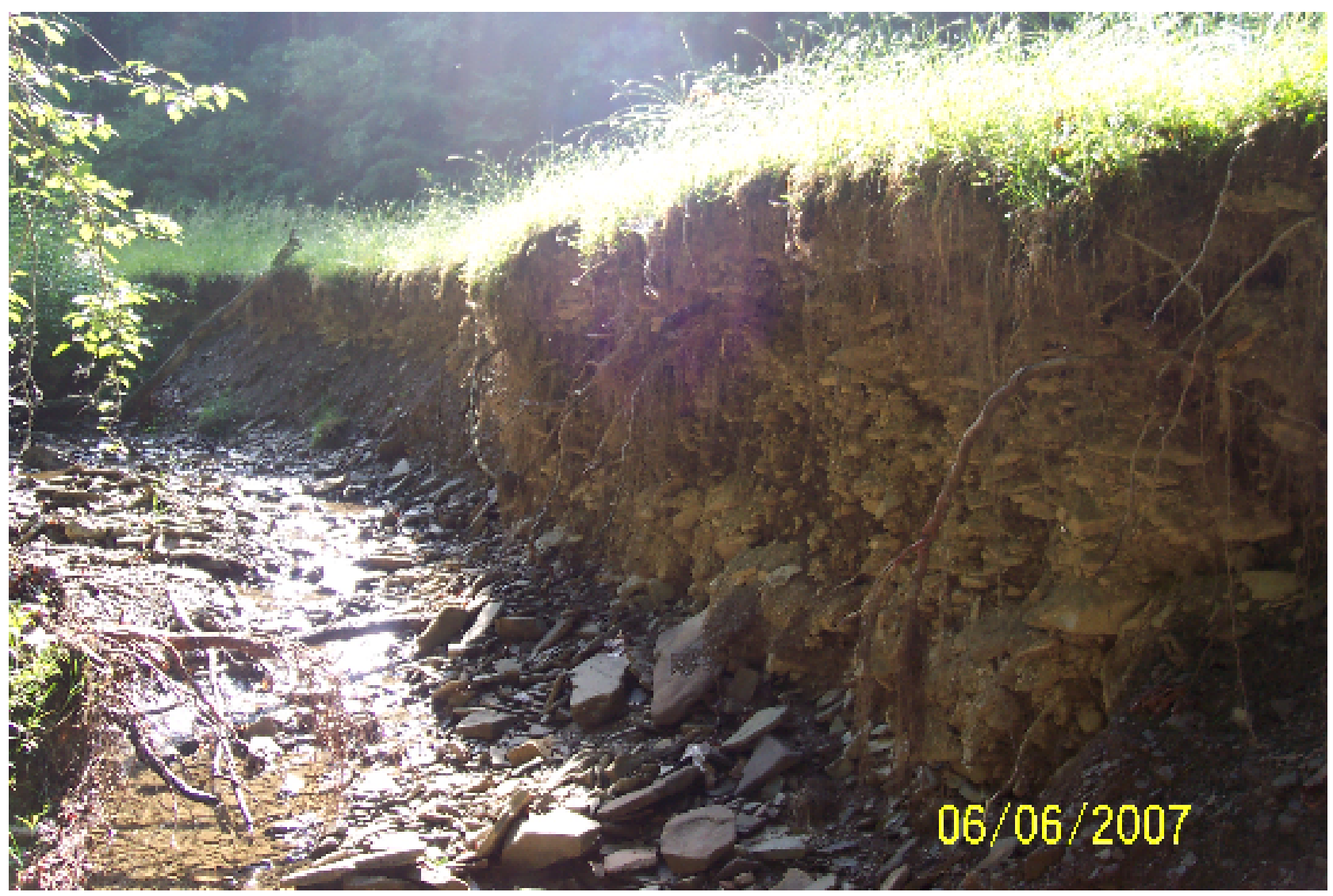

Figure 8: Photograph of a coarse grained alluvial terrace within Horseshoe Run watershed. Terrace is composed of coarse, subangular to subrounded pebbles and cobbles exposed by a tributary to Horseshoe Run. Sediment within terrace was most likely introduced into the fluvial system through upstream landslides and debris flows. 


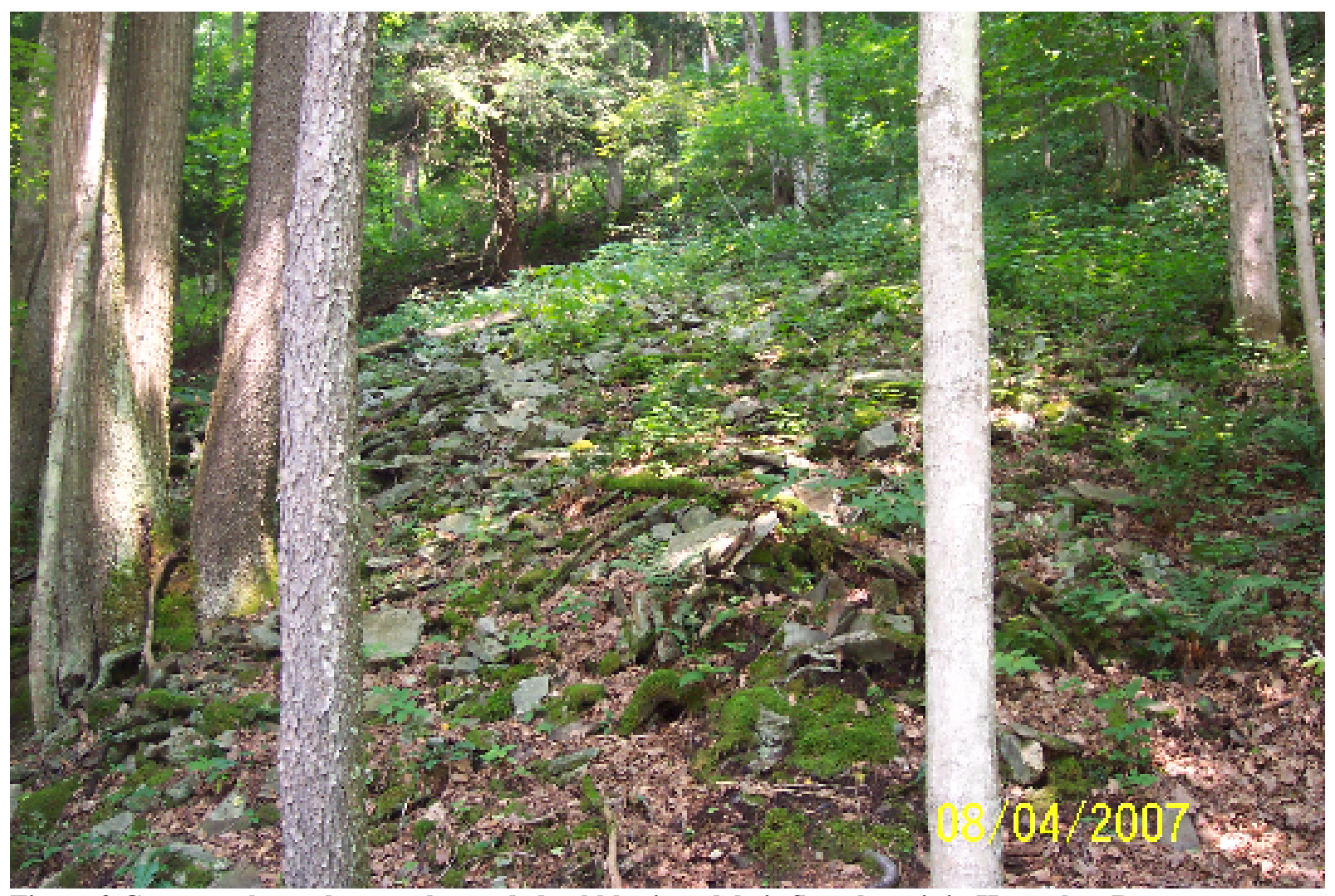

Figure 9 Coarse, subangular to subrounded cobbles in a debris flow deposit in Horseshoe Run watershed. 


\section{Previous Studies:}

Heavy rainfalls often trigger slope movements (Neary and Swift, 1987). In November 1985, heavy rainfalls occurred in eastern West Virginia as a result of complex meteorological events. Hurricane Juan brought moisture into the southern Appalachian Mountains from the Mississippi Valley, which helped to cause a high-pressure anticyclone to become stationary over southeastern Canada while a second low-pressure cyclone moved into the Appalachian region from the Atlantic coast (Colucci et al., 1991). This storm caused many slopes to fail throughout the Germany Valley of Eastern West Virginia and adjacent Virginia (Jacobson et al., 1987). Similarly, in September 2004, the remnants of Hurricane Ivan released heavy rains in Macon County, North Carolina. The heavy rainfall caused a debris flow to occur with an estimated maximum velocity of 14.8 $\mathrm{m} / \mathrm{s}$ and a discharge of $1275.2 \mathrm{~m}^{3} / \mathrm{s}$ (Latham et al., 2007). This debris flow caused significant damage to the town below, destroying 15 homes, killing 5 people, and ripping and throwing adjacent trees from its path (Latham et al., 2007).

Since there is no practical way to eliminate episodes of intense infiltration and soil saturation either due to heavy precipitation from intense storms or sudden snow melt, identification of areas prone to slope failure provides the best means to reduce landslide risk. Identification of landslide prone areas must be based on hillslope conditions prior to precipitation. Antecedent geologic conditions can be determined in the field by using standard geological surveying methods and the use of GIS (Carrara et al., 1999).

Slope movements triggered by heavy rainfalls occur as a result of increased pore pressure within the hillslope material (Bakersville and Ohlmacher, 1987). These slope 
movements often fail initially along bedding planes where the underlying bedrock is dipping in the down-slope direction (Jacobson et al., 1987). Many studies have been able to link the underlying bedrock and structural geology to increased risk of slope failure, yet other studies have been unable to determine such correlations (Williams and Guy, 1971). These differences in being able to link the underlying geology to slope failures may be explained by the different rock types present in each study area. Jacobson et al. (1987) were studying landslides that initiated within sedimentary lithologies and utilized bedding planes, while Williams and Guy (1971) were studying slope failures in the Blue Ridge region of Virginia where the underlying geology is metamorphic and igneous rocks. Although Williams and Guy (1971) did observe jointing within the rocks, they concluded that the joints were not as important as other factors. Still, other studies suggest that slope aspect will have a direct influence on the risk of slope failure (Gryta and Bartholomew, 1987). Kish, 2004, determined slope aspect was a contributing factor to slope failure, however, he recognized that slope aspect was related to another controlling factor; access roads for mining operations.

Underlying lithology and its associated slope material are other well-documented factors contributing to slope failure. Debris flows commonly occur in areas where the underlying bedrock is a non-resistant shale (Jacobson et al., 1987; Lorente et al., 2002; Outerbridge, 1987). These underlying shale units are associated with clayey residuum and if the clays in the residuum are expandable, chances of slope failure are greatly increased (Behling, 1987).

Vegetation can also have a great influence on the slope stability. A slope is considered stable if it is heavily vegetated with trees or plants whose roots extend deep 
within the hillslope soil. In contrast, if a slope is covered with only grasses, whose roots extend only into the near surface of the soil, the slope will be less stable (Brooks and Brierley, 1996). The worst case vegetational scenario for slope stability is a barren sloping surface. Without vegetation securing the hillslope, small additions of precipitation, could result in some form of slope movement. Barren slopes most often occur in places influenced by humans or by wildfire. Intense logging, mining, road construction, and many other anthropogenic alterations of hillslopes can cause great increases in risk of slope failure (Behling, 1987).

Researchers in the past created landslide risk maps by hand, identifying only those factors that seemed most important to slope initiation, such as slope angle, vegetation, and lithology. Although these maps were created using the technology at hand, they often relied on qualitative assessments. As studies of landslides and debris flows began to use more of a quantitative approach, they were met with mixed results (Carrara et al., 1999). Factors that determine slope stability have been shown to be both quantitative (slope angle, aspect, tree density) and qualitative (land use, soil type, geology) variables. However, converting qualitative variables into quantitative variables can be rather subjective, and should be approached with as little bias as possible. Therefore, given that the stability of a hillslope can be influenced by so many factors, many recent studies have relied on statistical analysis to try and determine those areas with higher risk for slope failure (Muriuki et al., 2007; Coelho-Netto et al., 2007; Komac, 2006). The increasing versatility of GIS, and the ease at which multiple factors can be integrated, have influenced the current trend of research towards using statistical spatial 
analysis and GIS to create these landslide risk assessment maps (Baeza and Corominas, 2001; Dai et al, 2004; He et al., 2003; Ohlmacher et al., 2003; Rickenmann, 1999).

There can be, however, disadvantages in using GIS to create a landslide susceptibility map as noted by Carrara et al. (1999). Disadvantages stem from two main areas: 1) any user, experienced or not, can create overlay maps in a GIS, and 2) since the outputs of an overlay analysis are subjective, they can be created by biased users to create inaccurate results. Bias is a major problem with creating overlay maps and it exemplifies how truly subjective these models can be. Statistical analysis should be used prior to any data manipulation within a GIS to avoid such subjectivity. This technique was used by Baeza and Corominas (2001), to properly identify the most influential factors of slope stability within their study area, and then from those results successfully classify $95.6 \%$ of failed slopes. In their study, they used a principal component analysis, a $t$-test, and one-way test to select the factors with the most significance. Performing a principal component analysis, allowed them to not only select the factors of most influence, but also determine which factors were conditionally independent from each other. They then used those factors that were independent and most influential as input variables in a discriminant analysis for a final step in their study.

Assessment and prediction of where future landsliding may occur, and the degree of risk associated with a given area, is an underlying objective of most landslide studies. If accurate results are achieved from a landslide susceptibility model, risks to life and property can be minimized. Therefore, transfer of knowledge between researchers, decision makers, and the general public is essential. However, the numerous different 
approaches and the varying results associated with those approaches limit the use of a standard method.

The lack of a standard method for landslide susceptibility models has led some the more current landslide studies to compare the results between differing approaches. Galli et al. (2008) compared landslide inventory maps for the Umbria region in central Italy. The three maps Galli et al. compared had different scales and were created in different years. The objectives of their study were to ascertain how well the inventory maps 1) described the location, type, and abundance of the landslides, 2) determine the characteristics of the failed areas, and 3) provide reliable information to construct landslide susceptibility models. The results of their study suggest that the scale used to map the landslides, the quality of the aerial photographs or remotely sensed imagery, and the time allotted for the study greatly influence the final landslide inventory map. Due to the importance of inventory maps and the underlying subjectivity associated with them, Galli et al. (2008) propose different methods for testing accuracy. Furthermore, they strongly encourage careful and detailed inventory mapping to facilitate accurate landslide susceptibility models, an important step commonly overlooked by researchers performing statistical analyses.

Similar studies have been performed for debris flow susceptibility models. Carrara et al. (2008) created five different models to predict locations of debris flow source areas within the Eastern Italian Alps. The models differed in approach: either statistically or physically-based, and the type of terrain unit of reference: slope unit or grid cell. Slope gradient, land use, availability of detrital material, and active erosional processes were shown to have the greatest influence in all their models. Despite the 
comparable results, they concluded that the discriminant model using small slope units was the best approach to predicting regional debris flows in their study area.

Although the use of GIS and remote sensing offers a relatively easy and time efficient approach, researchers should be cautious and understanding of the limitations and assumptions associated with landslide modeling. Perhaps one of the biggest complications stems from landslide classification. The classification of landslides forces naturally occurring phenomena, which vary over a continuous spectrum, into discrete categories, and often landslides are complex and have characteristics that fall into different categories simultaneously (Alexander, 2008). Another complication in landslide modeling is the quality of input data, consisting of both landslide inventories and landscape variables (Carrara and Pike, 2008). This quality of data complication reiterates the point made by Galli et al. (2008) that inferior observations are commonly gathered quickly in order to apply the data manipulation and multivariate statistical analysis so easily conducted within GIS. However, the sophistication of the technology and methods can not compensate for substandard input data (Carrara and Pike, 2008), and use of such careless models can have devastating consequences to human life and property.

To improve the quality and accuracy of input data for landslide models, remote sensing techniques such as light detection and ranging (LiDAR) can be utilized. LiDAR data are extremely accurate and have the ability to provide invaluable information for relatively large study areas. Yet, regardless of the quality of landscape imagery, careful observations by trained researchers are still required. Along with high resolution imagery, careful selection of landscape variables should be performed in order to maximize the accuracy of the landslide susceptibility model. 


\section{Methodology:}

\section{Surficial Geology Map:}

High-resolution LiDAR data and aerial photos were obtained by CVI via an Optech ALTM 3100 sensor, and an integrated 3 band digital camera (Bennett, 2007). Data acquisition was conducted in 2006 during leaf-off conditions at a flight altitude of 3500 meters above ground level at an air speed of 135 knots (Kinder, 2008).

Additionally, the pulse frequency of the sensor was set at $70 \mathrm{kHz}$ with a half scan angle of $20^{\circ}$ and a scanning frequency of $35 \mathrm{kHz}$ (Kinder, 2008). Flight plans were designed with $50 \%$ overlap in the swaths and a maximum of 4 waveform returns. The LiDAR data allowed creation of a Digital Elevation Model (DEM) with 0.5 m resolution and roughly $15 \mathrm{~cm}$ vertical accuracy (Kinder, 2008). These operational parameters and conducting LiDAR data acquisition during leaf-off conditions allowed for a highly accurate, high resolution DEM to be created and provided an invaluable method for remote mapping of surficial features within the watershed.

Post-processing of the LiDAR data to create the $0.5 \mathrm{~m}$ DEM was conducted by CVI. From the LiDAR-derived DEM, a shaded relief map was created within ArcGIS 9.2 (ESRI, 2007), using the spatial analyst toolbar, and served as a base map for both field observations and remotely mapped surficial features. Shaded relief maps were created by maintaining a sun altitude of $45^{\circ}$ and varying the sun azimuth. Four sun azimuths were used in this study: $45^{\circ}, 135^{\circ}, 225^{\circ}$, and $315^{\circ}$. These azimuths all provided useful information by illuminating surficial features on hillslopes within the watershed. The four azimuths were chosen because the main fold axis of the watershed is striking roughly 
north $-45^{\circ}$ east, and the hillslope aspects within the watershed appear to be, in part, structurally controlled.

The surficial geology map was constructed at a 1:12,000 scale using data gathered in the field and visual inspection of the LiDAR-derived shaded relief maps constructed by Konsoer and Downing at West Virginia University. Field observations were mapped onto LiDAR-derived shaded relief base maps and waypoints were taken using a Garmin handheld 12-channel GPS unit with $10 \mathrm{~m}$ accuracy to facilitate the digitization process within ArcGIS 9.2. GPS waypoints correlated well with the LiDAR-derived images (Figure 10), and due to the rugged, steep and heavily vegetated field conditions and extremely high resolution of the LiDAR data, once a firm correlation between field data and GIS data was established, mapping was conducted remotely using the LiDARderived shaded relief maps and the high quality aerial photographs, at a scale of 1:3000. More accurate delineations and precise locations of unit boundaries could be made by digitizing at a scale of 1:3000. Surficial features were remotely delineated based upon surface expression and morphology and digitization was conducted using ArcGIS 9.2. During the digitization process, each adjacent surficial unit polygon boundaries were snapped together to ensure no spaces within the mapping area were left unmapped. 


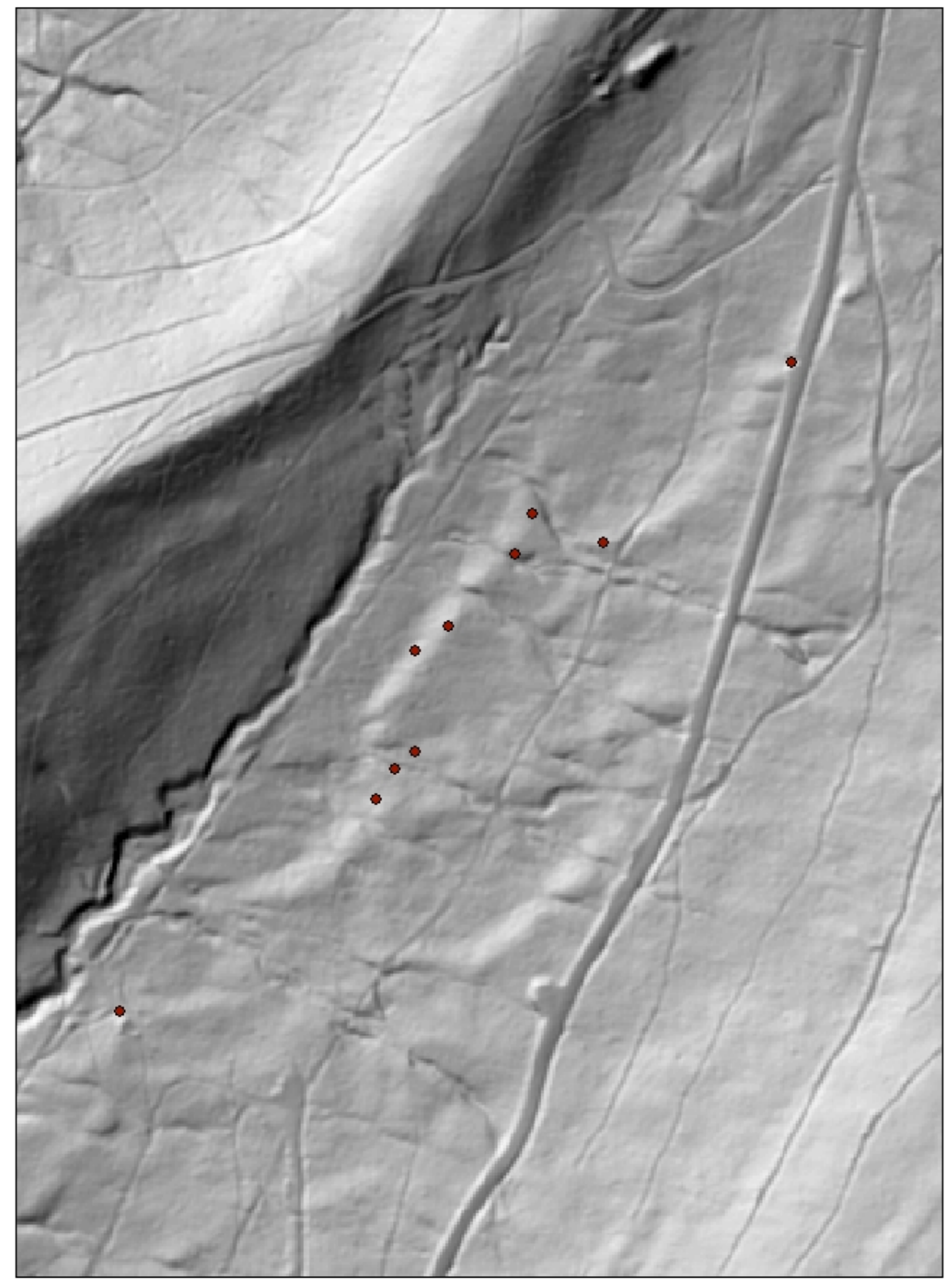

Figure 10: Bouldery gelifluction lobes on Backbone Mountain. Red dots indicate GPS waypoints taken in the lobes and show a good correlation between field observations and the high quality LiDAR-derived shaded relief map. General location of these lobes features are shown as number 2 on Figure 1. 
Surficial features mapped within Horseshoe Run watershed were as follows, undifferentiated colluvium, bouldery colluvium, bouldery gelifluction lobes, undifferentiated residuum, active floodplain, erosional strath terraces, active stream channels, paved and logging roads, and slope movements. Undifferentiated colluvium was mapped within the Devonian Chemung and Hampshire formations, and was typically composed of cobble and pebble, poorly sorted diamictons. In contrast, the bouldery colluvium was mapped within the areal extent of the Mississippian and Pennsylvanian formations, where large sandstone boulders and cobbles from the Pottsville Formation accumulated along ridge crests and in concave hillslope and local karst depressions. Table (2) shows the different surficial landforms and deposits mapped in Horseshoe Run watershed, and characteristics used to delineate between surficial geology features.

\section{Selection of Variables:}

In order to create an objective landslide susceptibility model, data are required for the entire study area, not just areas of slope failure. The importance of having both failure and non-failure sites in analysis makes data acquisition cumbersome and difficult when

working in large study areas such as the $144 \mathrm{~km}^{2}$ Horseshoe Run watershed. Therefore, the variables that were chosen in this study were variables that could be created within ArcGIS 9.2 quickly and easily, yet still provide high quality data. As a result, variables that have been previously shown to influence slope failure, such as regolith thickness, soil texture, and structural geology, could not 


\begin{tabular}{|c|c|}
\hline Surficial landform feature & $\begin{array}{l}\text { Characteristics used to delineate and map } \\
\text { feature }\end{array}$ \\
\hline Active Slopes & $\begin{array}{l}\text { Slopes actively moving due to oversteepening } \\
\text { and undercutting by active channels. }\end{array}$ \\
\hline Planar Slides (slides) & $\begin{array}{l}\text { Uniform block glides and slides with } \\
\text { significant head scarps. Slide material appears } \\
\text { uniform and lacks hummocky topography and } \\
\text { a clearly defined slide toe. }\end{array}$ \\
\hline Rotational Slumps (slumps) & $\begin{array}{l}\text { Landslides having lobate and hummocky } \\
\text { topography in the toe region of the slide and a } \\
\text { visible head scarp. }\end{array}$ \\
\hline Debris Flows & $\begin{array}{l}\text { Unconsolidated material confined to hillslope } \\
\text { hollows with evidence of fluid like flow. } \\
\text { Debris material not transported to base of } \\
\text { hillslope and still remains confined in hollows. }\end{array}$ \\
\hline Debris Fans & $\begin{array}{l}\text { Unconsolidated material confined to hillslope } \\
\text { hollows. Debris material transported to base of } \\
\text { hillslope with a well defined depositional fan } \\
\text { present. }\end{array}$ \\
\hline Debris Slides & $\begin{array}{l}\text { Planar slide of unconsolidated material } \\
\text { confined to hillslope hollows. Debris slides } \\
\text { lack well defined depositional fans. }\end{array}$ \\
\hline Active Channel & $\begin{array}{l}\text { Primary channel conveying water at summer } \\
\text { base flow }\end{array}$ \\
\hline Active Floodplain & $\begin{array}{l}\text { Floodplain immediately adjacent to active } \\
\text { channel. Multiple secondary channels present } \\
\text { with evidence of periodic inundation. }\end{array}$ \\
\hline Alluvial Terrace 0 & $\begin{array}{l}\text { Lowest alluvial terrace above active floodplain. } \\
\text { Some secondary channels present with little } \\
\text { evidence of periodic inundation. }\end{array}$ \\
\hline Terrace Sequences T1-T4 & $\begin{array}{l}\text { Erosional strath terraces with a thin alluvial } \\
\text { veneer. Relative age increases from T1-T4. }\end{array}$ \\
\hline Undifferentiated Terraces & $\begin{array}{l}\text { Erosional strath terraces with a thicker veneer } \\
\text { and undifferentiable by relative age. }\end{array}$ \\
\hline Colluvial Boulder Front & $\begin{array}{l}\text { Gelifluction fronts composed primarily of } \\
\text { Pottsville Formation sandstone boulders. }\end{array}$ \\
\hline Bouldery Colluvium & Hillslopes covered in bouldery diamictons. \\
\hline Undifferentiated Colluvium & $\begin{array}{l}\text { Hillslopes covered in undifferentiated } \\
\text { diamictons. }\end{array}$ \\
\hline Undifferentiated Residuum & $\begin{array}{l}\text { Thin veneer of slightly weathered bedrock } \\
\text { restricted to ridge crests and slopes too steep to } \\
\text { keep material in place. Boulders and cobbles } \\
\text { may be present but have not been significantly } \\
\text { transported by gravitational forces. }\end{array}$ \\
\hline
\end{tabular}

Table 2: Classifications of surficial geology features and the characteristics used to remotely map them within Horseshoe Run watershed. 
be used in this model. However, seven variables (slope angle, slope aspect, elevation, plan curvature, profile curvature, distance from roads, and distance from streams) were carefully chosen to characterize the slope conditions and compensate for these "missing" variables, such as soil thickness and texture.

Slope angle and slope aspect were created using the surface analysis tool within the Spatial Analyst extension. Distance from roads and distance from streams were created by using the straight line distance tool within the Spatial Analyst extension. Plan curvature and profile curvature were created using the curvature tool located in the Spatial Analyst Tools. A watershed boundary was delineated by hand from the LiDARderived shaded relief maps, and this watershed boundary served as the study area extent for all mapping and calculations within ArcGIS 9.2.

Slope Angle -Slope angle is measured as the rate of change in elevation in the direction of steepest descent. Slope angle is a first order derivative calculated from the DEM. Slope angle is a dominant factor through which gravity induces movement of water and slope materials (Wilson and Gallant, 2000). Slope, therefore, has implications for the potential energy of the slope material and surface and subsurface flow of water.

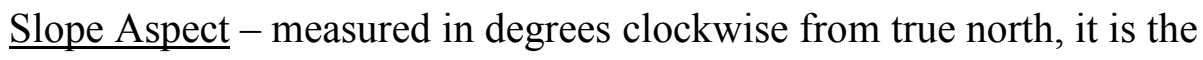
orientation of a slope in the direction of steepest descent (Wilson and Gallant, 2000). In other words, it is the direction a person would be looking while standing on the slope with their back facing upslope. Slope aspect has many implications, such as soil moisture content and vegetation as determined by solar radiation.

Elevation -Elevation is measured as the vertical distance above mean sea level, measured in meters. Elevation is used to calculate numerous other variables, which can 
be either first or second derivatives, and has implications for potential energy, temperature, and vegetation (Wilson and Gallant, 2000).

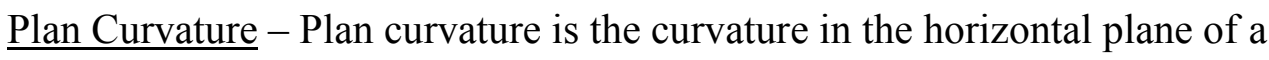
contour line, or the rate of change in aspect along a contour (Wilson and Gallant, 2000). Plan curvature is a second derivative of the DEM, and is a measure of the rate of change of a first derivative, slope aspect. Plan curvature values that are negative represent diverging flows and values that are positive represent converging flow. This variable allows determination of noses and hollows, and serves as a surrogate for convergence and divergence of flow across the landscape.

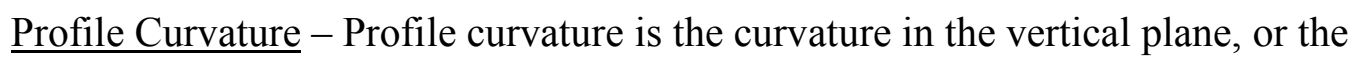
rate of change of slope of a contour-orthogonal line. Profile curvature is a second derivative of the DEM, and is a measure of the rate of change of the first derivative, slope angle. Profile curvature values that are negative represent increasing slope downhill (convex flow profile) and values that are positive represent decreasing slope downhill (concave flow profile). Profile curvature measures the rate of change of potential gradient and has implications for changes in flow velocity and sediment transport (Wilson and Gallant, 2000).

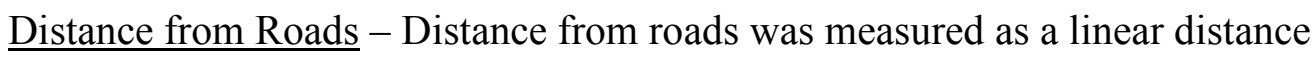
from mapped out roads. Although paved roads reduce the rate and capacity of infiltration, diversion of surface water into ditches may increase infiltration and decrease slope stability. Cuts and fills associated with roads commonly create local instabilities and promote slope failure. 
Distances from Streams - Distance from streams was measured as a linear distance from mapped active channels. Streams may be erosional agents, removing slope material from the base of a slope, causing over-steepening and eventual failure of the slope. Slopes that are in close proximity to active channels are at higher risk of slope failure than those slopes at distance.

\section{Mapping of the Landslides:}

Mapped landslides were categorized as planar slides, rotational slumps, debris fans, debris flow, debris slides, or active slopes. Assignment of individual slope movements into a category was performed by visual inspection of the LiDAR-derived shaded relief map, focusing at surface morphology, head scarps, and displacement of slope material (Table 2). Numerous remotely mapped slope movements were field checked in order to insure proper classification. The classification of landslides was based upon classification schemes proposed by Varnes (1978), Campbell et al. (1985), and Hungr et al. (2001).

Debris fans were classified as unconsolidated material confined to hillslope hollows. The debris material has been transported to the base of the hillslope with a well defined depositional fan spreading out on the floodplain and evidence of a fluid-like debris tail (Figure 11). Debris flows were mapped separately from the debris fans because the debris flows were still confined within the hillslope hollow. These unconsolidated slope failures display fluid-like flow and lack a depositional fan (Figure 12). Debris slides were mapped as planar slides of unconsolidated material confined within hillslope hollows, having hummocky topography, and lacking evidence of fluid-like flow (Figure $13)$. 


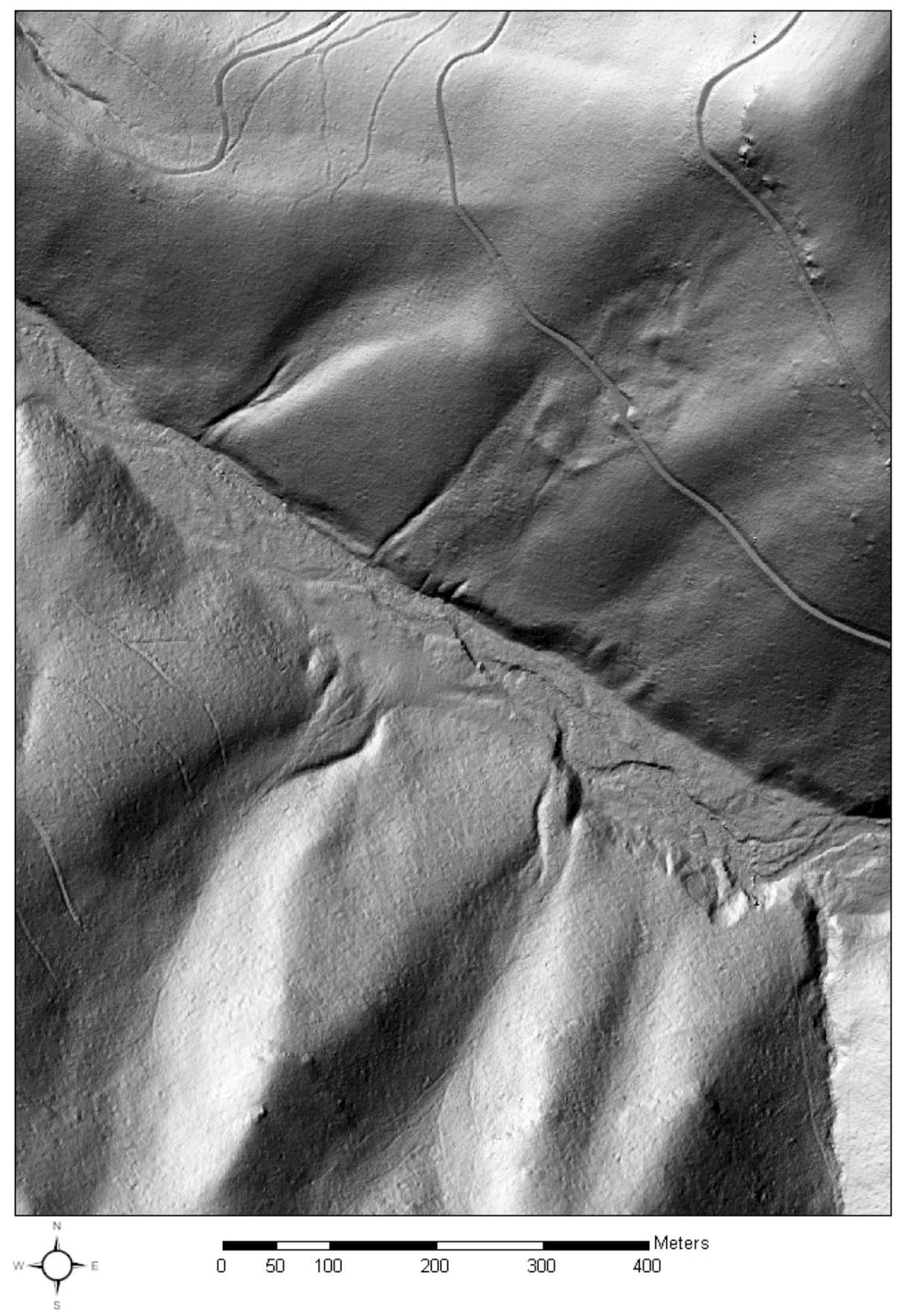

Figure 11: LiDAR-derived shaded relief map image showing an example of a debris fan. Location of this debris fan is shown as number 3 on Figure 1. 


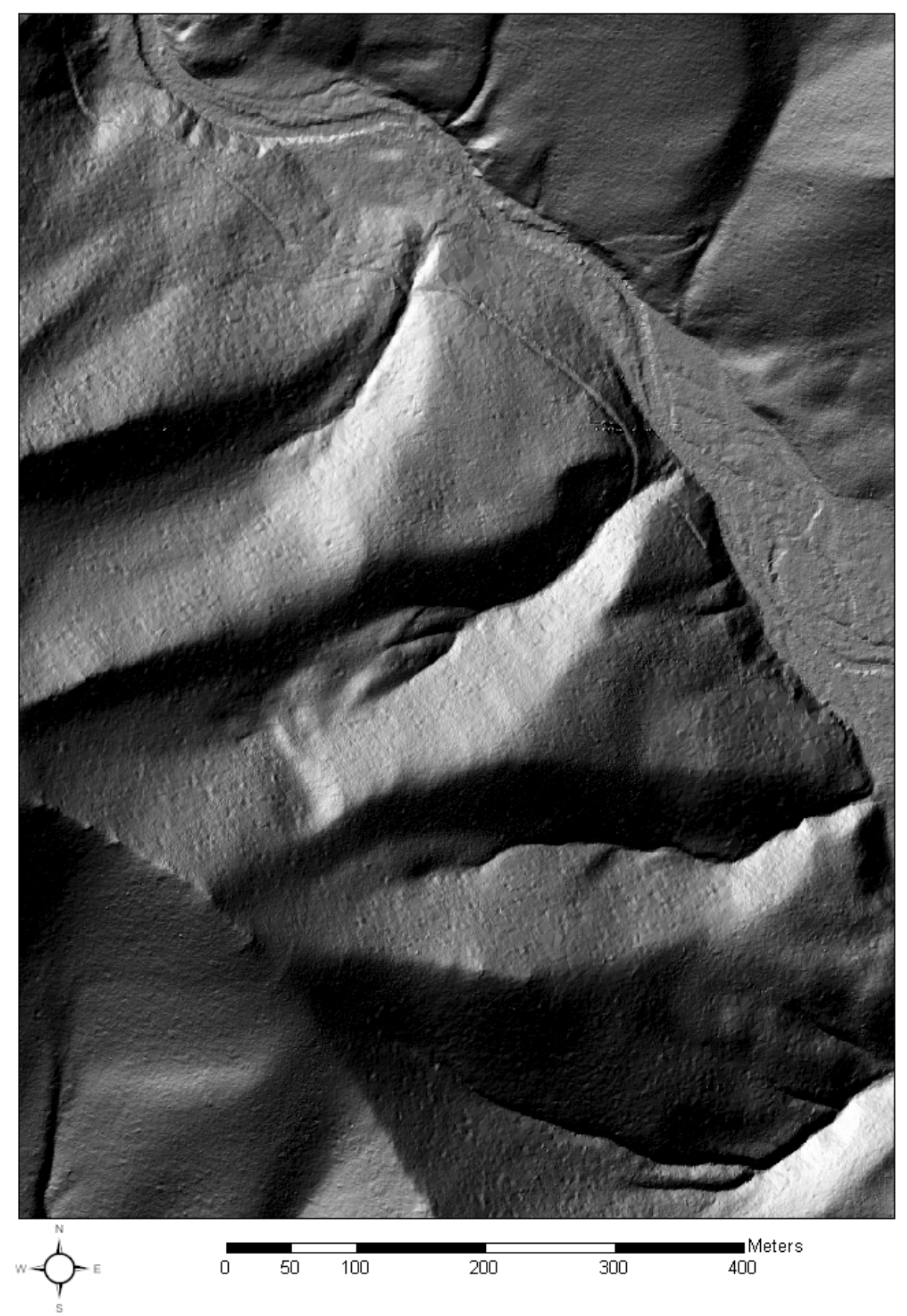

Figure 12: LiDAR-derived shaded relief map showing an example of a debris flow. Location of debris flow is shown as number 4 on Figure 1. 


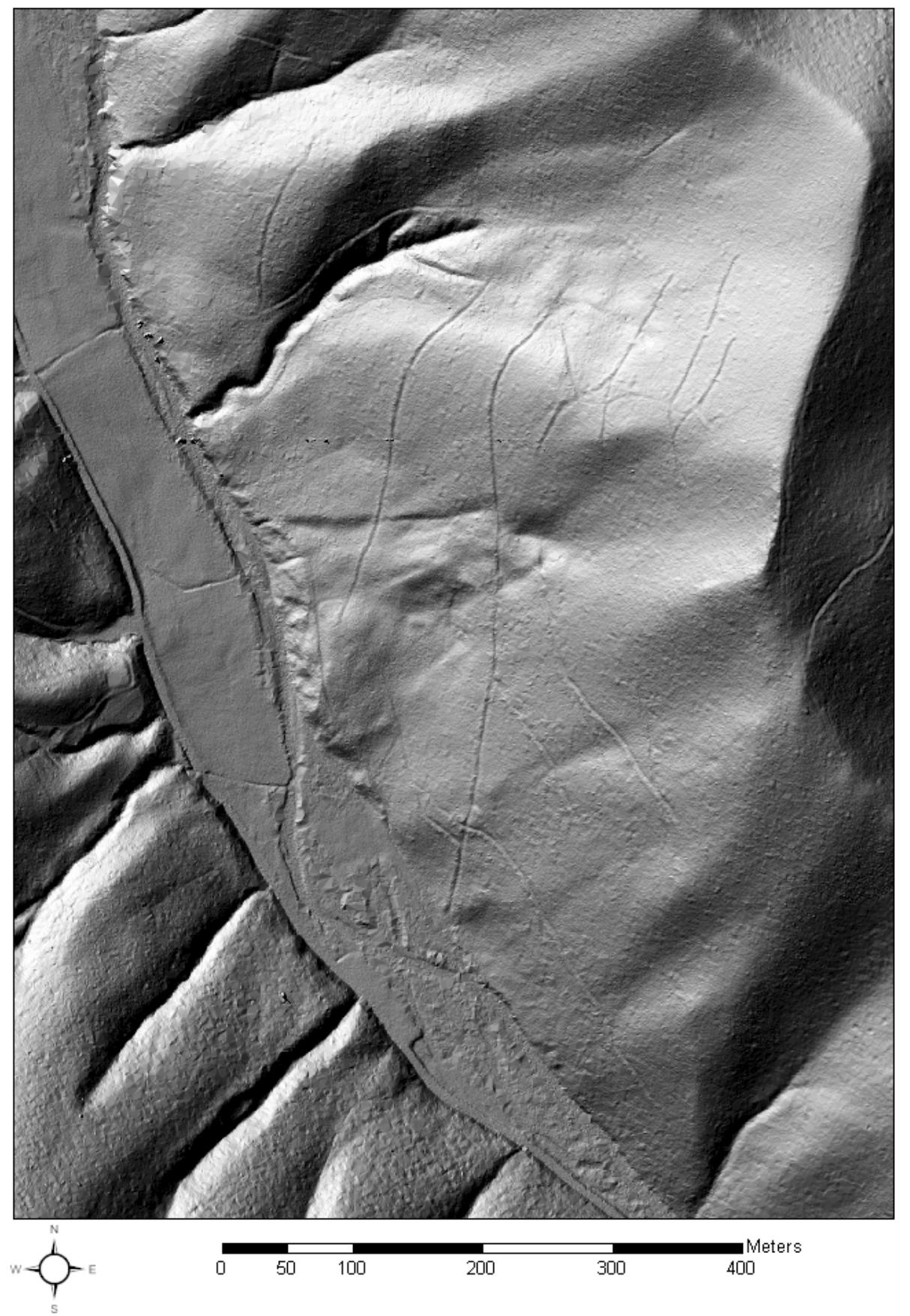

Figure 13: LiDAR-derived shaded relief map showing an example of a debris slide. Location of debris slide is shown as number 5 on Figure 1. 
Planar slides were mapped as being a relatively uniform block displaying translational glides and slides with significant head scarps. These planar slides lack hummocky topography and display no signs of a slide toe (Figure 14). Rotational slumps display hummocky topography, secondary scarps within the failure, and have a well defined slide toe at the base of the failure. These slumps also lack a well defined head scarp, suggesting more of a vertical head scarp failure and not a lateral displacement as seen with the planar slides (Figure 15). Lastly, the active slopes were classified as slopes actively moving due to oversteepening and undercutting by the active channels (Figure $16)$.

\section{Statistical Analysis of Landslides:}

The landslide inventory map shows the spatial distribution of displaced slope material. The purpose of this project, however, was to determine the conditions under which slope failure occurs. To determine the conditions, initiation points were identified for each landslide through visual inspection of head scarps, erosional surfaces, and slope breaks on hillslope profiles. These initiation points were then buffered, using a 4 meter buffer tool within ArcGIS 9.2, to create polygons for data generation. Buffering of the initiation points allowed for an average of roughly 14 raster cell attributes to be calculated, instead of a single cell that could bias results because of microscale variability or errors in LiDAR data.

The LiDAR-derived DEM was resampled to create a $2 \mathrm{~m}$ DEM from the original $0.5 \mathrm{~m}$ DEM. This transformation to lower resolution data allowed for a smaller data set and faster calculations within ArcGIS 9.2, without sacrificing resolution required to map 


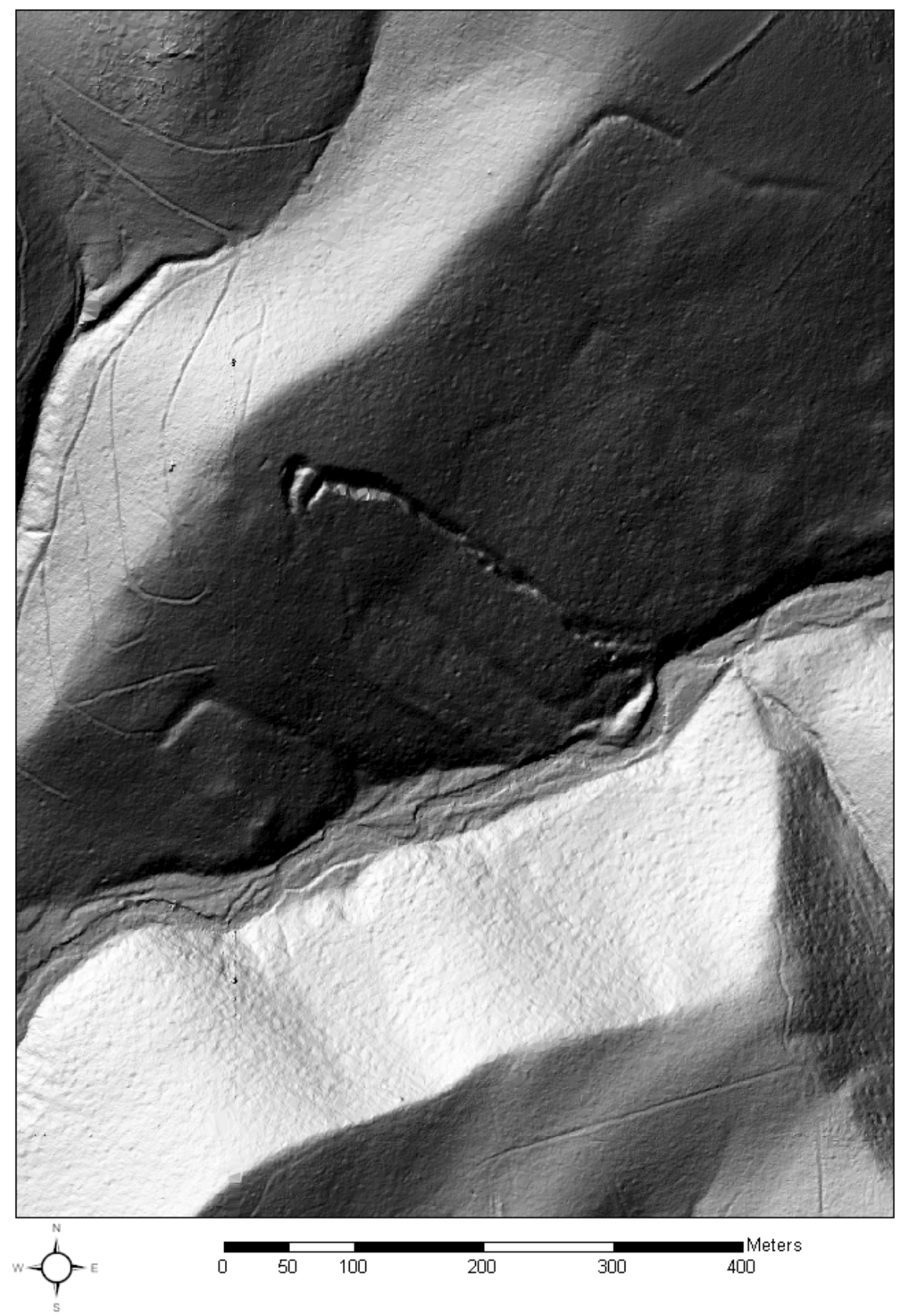

Figure 14: LiDAR-derived shaded relief map showing an example of a planar slide. Location of planar slide is shown as number 6 on Figure 1. 


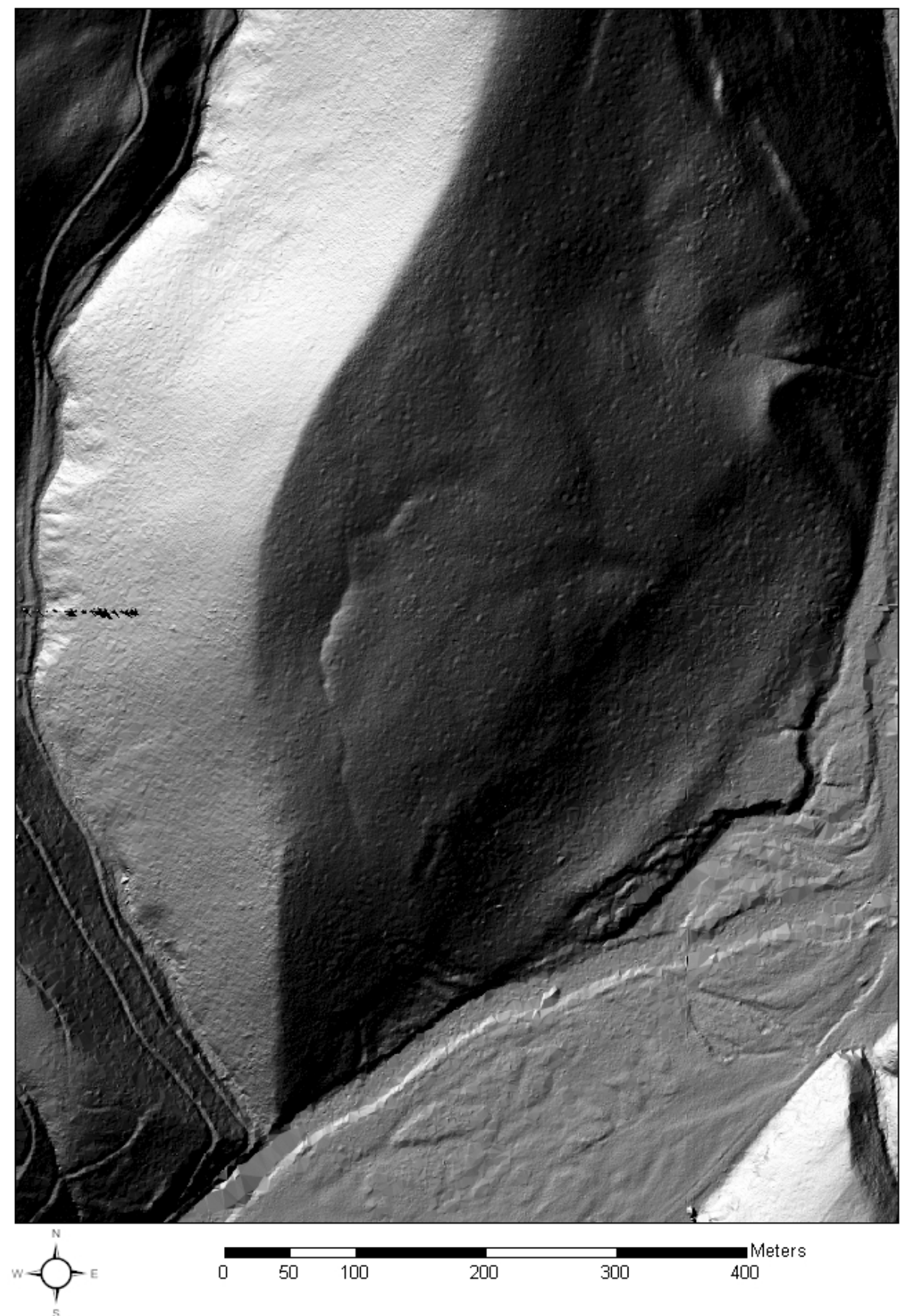

Figure 15: LiDAR-derived shaded relief map showing an example of a rotational slump. Location of rotational slump is shown as number 7 on Figure 1. 


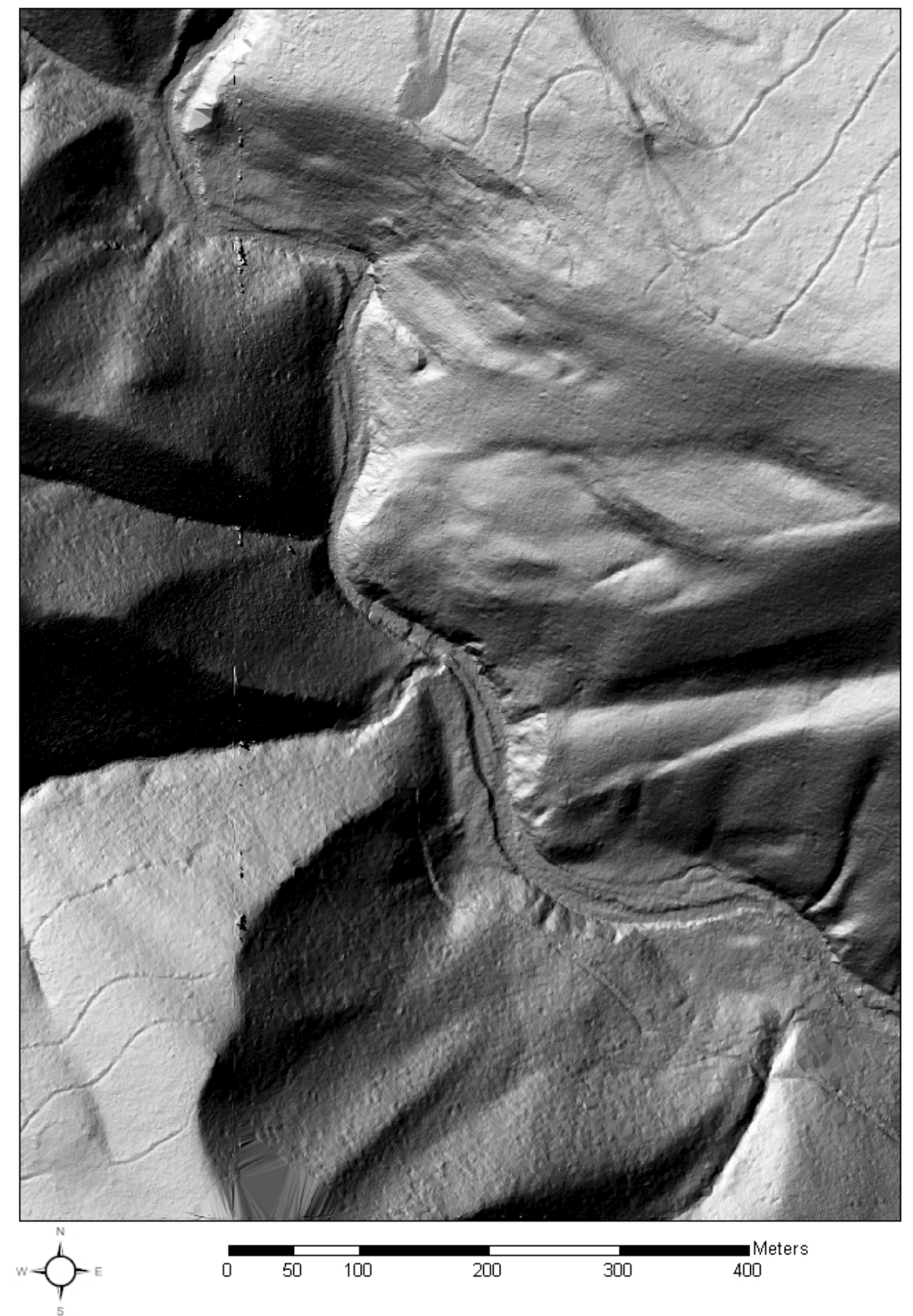

Figure 16: LiDAR-derived shaded relief map showing an example of an active slope. Location of active slope is shown as number 8 on Figure 1. 
at 1:12,000 scale. Seven different data layers were created from the LiDAR-derived DEM to serve as the variables for this study: slope angle, slope aspect, elevation, plan curvature, profile curvature, distance from roads, and distance from streams. Data collection was conducted using the zonal statistics function within the Spatial Analyst extension of ArcGIS 9.2. Output tables were combined to create a full landslide data table (Appendix A).

Unfailed slope data also were collected to compare with the failed slope data and determine any differences between the two populations. Unfailed slopes were randomly selected within the watershed using the Hawth's Tools extension within ArcGIS 9.2. The random selection created a shapefile of 150 points that were then buffered to $4 \mathrm{~m}$ to allow for an average of raster attributes to be calculated. Unfailed slope data were then gathered on the same seven variables using the same approach used for the failed slope initiation points. Output tables were combined to create an unfailed data table to use in the statistical analysis process (Appendix A).

Statistical analyses of the failed and unfailed data tables were conducted using Microsoft Excel 2007, Minitab 13.30, and Oriana 2.02e (Microsoft, 2007; Minitab Inc., 2000; Kovach Computing Services, 2007). Minitab 13.30 was used to determine mean, standard deviation, and variance for each variable on each type of slope movement (i.e. debris flow, slide, slump, unfailed). All variables were then tested for normality, and Box-Cox Transformations were performed within Minitab 13.30 to transform nonnormally distributed variables into normally distributed variables. These transformations were performed using the option of optimum lambda $(\lambda)$, which chooses the method of transformation that will produce the most normal distribution. 
The transformed data were then split into subgroups based upon the type of slope failure and tests of equal variance were performed for each pair. The tests for equal variances were performed in order to conduct two sample student's t-tests between each set of data. Student's t-tests are used to determine if there is significance between the means of two populations. The variables were then tested for any correlation and the data were entered into a discriminant analysis function to determine differences between landslide classifications. Oriana 2.02e software, specifically designed to work with circular data, was used to analyze the slope aspect data and create rose diagrams for each different type of slope movement for comparison between groups. Circular data, such as azimuth data, often have trends in two directions, for example NW-SE, and therefore require specific statistical analyses to be performed.

\section{Landslide Susceptibility Map:}

A landslide susceptibility map was created for Horseshoe Run watershed within ArcGIS 9.2 using the results from the multivariate statistical analysis comparing all failed slopes to all unfailed slopes. The discriminant analysis function, derived by Minitab 13.30, was entered into the Raster Calculator within the Spatial Analyst toolbar of ArcGIS 9.2. The output produced by the Raster Calculator assigns risk of failure values to each cell within the watershed. Higher risk values indicate a higher susceptibility for failure and lower risk values indicate relatively stable slopes. The values calculated by the raster calculator within ArcGIS 9.2 were then reclassified based on one standard deviation of the risk population distribution, and five categories were defined: low risk, low-medium risk, medium risk, medium-high risk, and high risk. These classification breaks were chosen because of the statistical background and resulted in the least user 
biased distribution. The landslide susceptibility map was then used to (1) identify those areas within the watershed that are at higher risk for slope failure, and (2) as an interpretative tool for assessing the overall hillslope stability of the watershed. 


\section{$\underline{\text { Results: }}$}

\section{Surficial Geology Map of Horseshoe Run watershed:}

The 1:12,000 scale surficial map of the watershed shows the spatial distribution of surficial deposits and landforms (Plate 1). Alluvium, colluvium, and residuum surficial deposits were mapped in the watershed. Mapped landforms consisted of slope movements, active channels, terraces, and active floodplains. Roads, both paved and logging, were also mapped from the high resolution LiDAR-derived shaded relief map.

The resistant quartzose lithologies that hold up Backbone Mountain result in interesting surficial geology landforms. Boulder fields and boulder streams, composed of the Pottsville sandstones and conglomerates, were concentrated in local hollows on the slopes of Backbone Mountain (Figure 17). Despite the high resolution of the LiDARderived shaded relief maps, boulder fields and boulder streams were unidentifiable on the image and, therefore, were not mapped. Long lobate landforms on the slopes of Backbone Mountain had surface morphology similar to gelifluction, or solifluction, lobes (Ritter, Kochel, and Miller, 2002). In either case, these identified features exhibit signs that they were slow moving surficial deposits of regolith. These lobate features (Figure 10) were identified from the LiDAR-derived shaded relief maps by a break in slope and in the field by the coarse grained boulders and cobbles located along the leading edge of the landform.

The Greenbrier Limestone on Backbone Mountain also created interesting surficial geology. Although obvious karst features, such as sinkholes and caves, were not observed at the surface during the field season, their presence is acknowledged by accumulation of large colluvial boulders and cobbles derived from the formations above. 
Numerous springs originating from the Greenbrier Limestone outcrop belt were identified in the field. These springs were often very diffuse, yet in many locations, where discharge of ground water was sufficient, localized channels formed. However, similar to the boulder fields and boulder streams, remote identification of the springs and the spring-fed channels using the LiDAR-derived shaded relief map was not possible and these features were not mapped. 


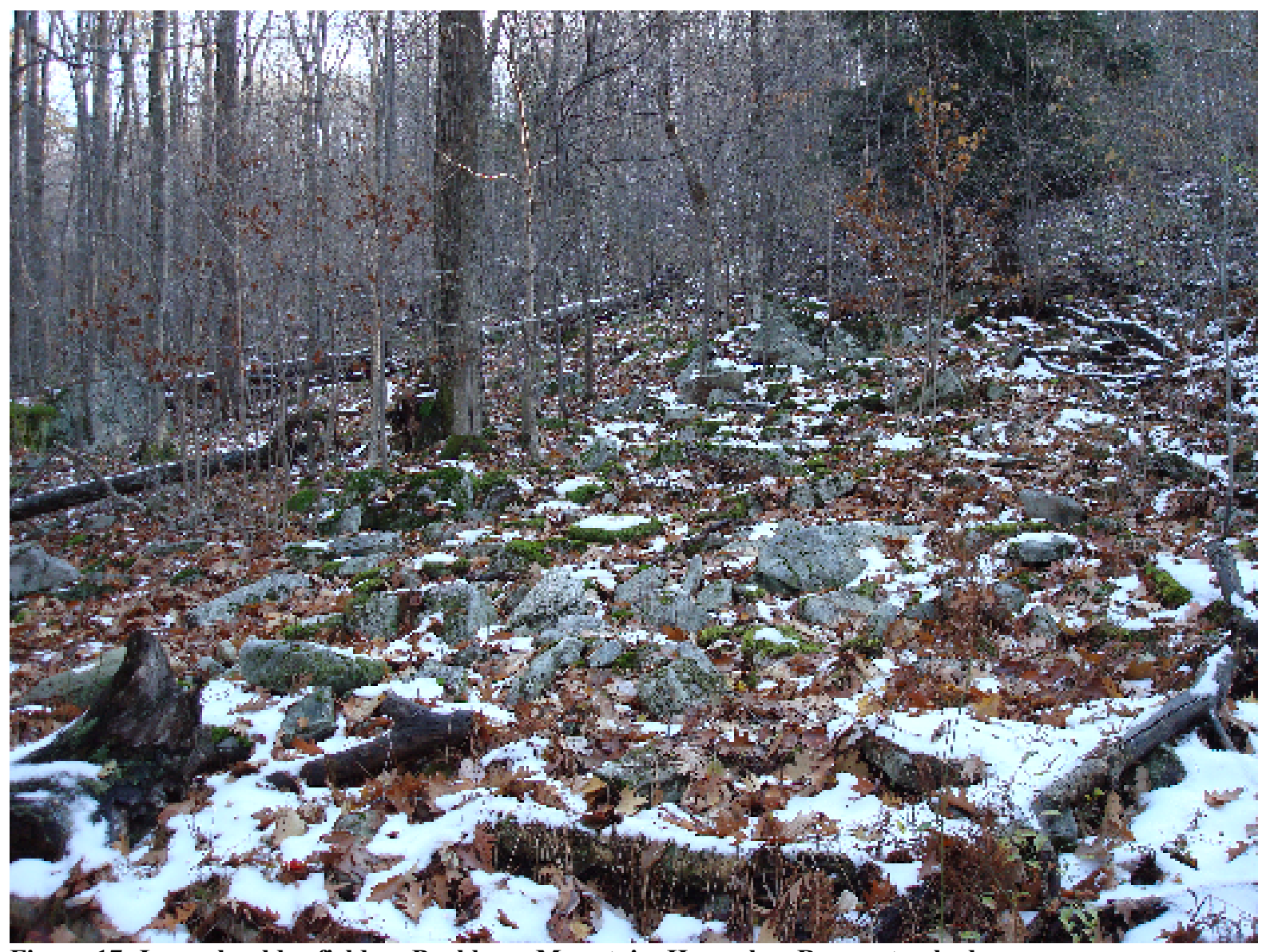

Figure 17: Large boulder field on Backbone Mountain, Horseshoe Run watershed. 


\section{Landslide Inventory Map and Statistical Analyses:}

The landslide inventory map (Plate 2) shows the spatial distribution of slope movements within Horseshoe Run watershed. The slope movements shown in the inventory map are classified according to the characteristics outlined in Table 2. Of the 152 different slope movements, rotational slumps are most abundant, followed by planar slides and active slopes (Table 3).

Each type of slope movement was analyzed over each of the variables, except for slope aspect, to determine mean, standard deviation, and variance (Table 4). Slope aspect data were analyzed separately from the other variables because these data are circular. The results of the remaining variables were used to compare between the different types of slope movements to determine if there was a statistical difference between populations. Significance between the variables was tested by using the two sample student's t-test, which tests whether two independent sample means are equal (Appendix B). The student's t-test was used for these data sets because there were less than 40 observed failures for each type of slope movement. Appendix C summarizes the means, standard deviations, variances, and normality for each type of landslide.

The landslide summary data were then tested for correlation between variables using Minitab 13.30. The output correlation matrix shows that the seven variables are weakly correlated, as shown by the correlation coefficients, and therefore could be used in a discriminant analysis. Multiple discriminant analyses were implemented to determine which model had the highest level of accuracy. One of the most accurate models compared all failed slopes to all unfailed slopes (Figure 18). This model accurately identified $71.8 \%$ of the slopes. A Discriminant analysis using the different types of failed 
slopes, along with the unfailed slopes, was $59.2 \%$ accurate at classifying slope movements to a specific type of failure (Figure 19). However, a discriminant analysis using only failed slope data resulted in accurate specific landslide type classification for $76.3 \%$ of failed slopes (Figure 20). These results indicate that there is a statistical difference between unfailed slopes and, failed slopes, and also between the different types of slope movements.

Slope aspect data were analyzed within Oriana 2.02e, software designed to work with circular data such as azimuths. Rose diagrams were created for each type of slope movement. Results from these graphs show that there is a difference in preferred orientation between the different types of slope movements. Planar slides and rotational slumps occur most often on northwest and southeast facing slopes, whereas debris flows and debris fans occur most often on northeast facing slopes (Figures 21 and 22). Appendix D shows orientation data for each type of slope movement.

The results from the rose diagrams were compared to the unfailed slopes to determine if there was any correlation between slope aspect and slope angle. For example, debris flows occurred on slope angles averaging $30.3^{\circ}$. The unfailed slope angle data were subdivided into equal interval classes and each subdivision was plotted on a rose diagram (Appendix E). Comparing the rose diagram for the debris flows to the rose diagram for unfailed slope angles $28-32^{\circ}$ shows that these two populations are different (Figure 23). These results from the subdivided unfailed slope angle data suggest that there is no correlation between slope aspect and slope angle. Therefore, the results from comparisons of slope aspect between failed slope types are valid. 


\begin{tabular}{|l|l|}
\hline Type of Landslide & $\begin{array}{l}\text { Number of } \\
\text { Individual } \\
\text { Landslides } \\
\text { Identified }\end{array}$ \\
\hline Active Slopes & 28 \\
\hline Debris Fans & 17 \\
\hline Debris Flows & 17 \\
\hline Debris Slides & 13 \\
\hline Planar Slides & 38 \\
\hline Rotational Slumps & 39 \\
\hline
\end{tabular}

Table 3: Number of different types of slope movements mapped within Horseshoe Run watershed. 


\begin{tabular}{|c|c|c|c|c|c|c|}
\hline $\begin{array}{l}\text { Type of Slope } \\
\text { Movement }\end{array}$ & $\begin{array}{l}\text { Slope Angle } \\
\left({ }^{\circ}\right)\end{array}$ & $\begin{array}{l}\text { Elevation } \\
(\mathrm{m})\end{array}$ & $\begin{array}{l}\text { Plan Curvature } \\
\text { (radians per meter) }\end{array}$ & $\begin{array}{l}\text { Profile Curvature } \\
\text { (radians per meter) }\end{array}$ & $\begin{array}{l}\text { Distance to } \\
\text { Roads (m) }\end{array}$ & $\begin{array}{l}\text { Distance to } \\
\text { Streams (m) }\end{array}$ \\
\hline Active Slopes & 35.95 & 563.75 & -1.04 & -1.70 & 219.22 & 61.30 \\
\hline Planar Slides & 21.77 & 670.39 & -0.94 & 1.86 & 139.69 & 210.78 \\
\hline Rotational Slumps & 21.03 & 680.53 & -0.40 & 0.67 & 118.06 & 234.95 \\
\hline Debris Fans & 26.12 & 662.44 & -3.25 & 0.49 & 90.68 & 230.51 \\
\hline Debris Flows & 30.30 & 717.16 & -1.52 & 0.07 & 115.78 & 440.88 \\
\hline Debris Slides & 32.28 & 625.49 & 0.11 & -0.61 & 217.79 & 220.73 \\
\hline Unfailed Slopes & 19.25 & 702.73 & 0.10 & 0.17 & 142.24 & 347.57 \\
\hline
\end{tabular}

Table 4: Mean values of landscape variables used in the landslide analyses for the different types of slope movements. 


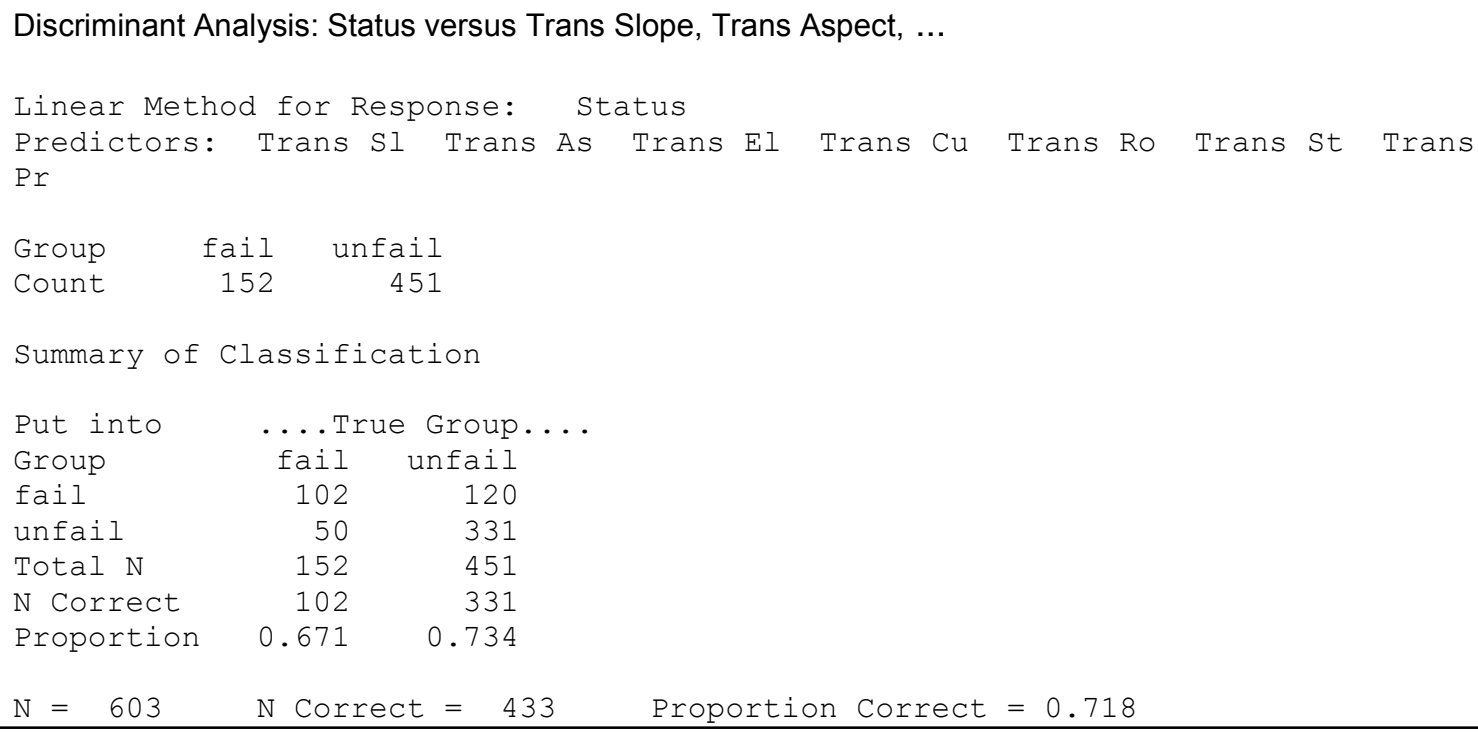

Figure 18: Summary of discriminant analysis of failed versus unfailed slopes within Horseshoe Run watershed. 


\begin{tabular}{|c|c|c|c|c|c|c|c|}
\hline \multicolumn{8}{|c|}{ Discriminant Analysis: Type versus Trans Slope, Trans Aspect, ... } \\
\hline \multirow{2}{*}{\multicolumn{8}{|c|}{$\begin{array}{l}\text { Quadratic Method for Response: Type } \\
\text { Predictors: Trans Sl Trans As Trans El Trans Cu Trans Ro Trans St Trans Pr }\end{array}$}} \\
\hline & & & & & & & \\
\hline \multirow{2}{*}{\multicolumn{8}{|c|}{ 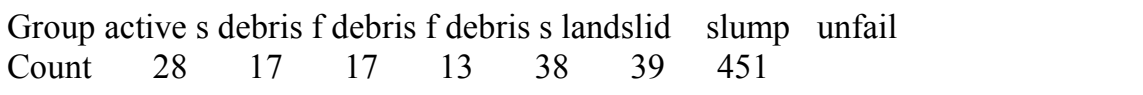 }} \\
\hline & & & & & & & \\
\hline \multicolumn{8}{|c|}{ Summary of Classification } \\
\hline \multicolumn{8}{|c|}{ Put into $\quad$....True Group.... } \\
\hline \multicolumn{8}{|c|}{ Group active $s$ debris $f$ debris $f$ debris $s$ landslid slump unfail } \\
\hline active $\mathrm{s}$ & 27 & 0 & 0 & 0 & 3 & 1 & 19 \\
\hline debris $\mathrm{f}$ & 0 & 13 & 2 & 1 & 1 & 2 & 25 \\
\hline debris $\mathrm{f}$ & 0 & 2 & 15 & 1 & 1 & 0 & 10 \\
\hline debris $\mathrm{s}$ & 1 & 1 & 0 & 10 & 4 & 4 & 24 \\
\hline landslid & 0 & 0 & 0 & 0 & 20 & 4 & 43 \\
\hline slump & 0 & 1 & 0 & 1 & 6 & 25 & 83 \\
\hline unfail & 0 & 0 & 0 & 0 & 3 & 3 & 247 \\
\hline Total N & 28 & 17 & 17 & 13 & 38 & 39 & 451 \\
\hline N Correct & 27 & 13 & 15 & 10 & 20 & 25 & 247 \\
\hline Proportion & 0.964 & 0.765 & 0.882 & 0.769 & 0.526 & 0.641 & 0.548 \\
\hline $\mathrm{N}=603$ & N Corr & ect $=35$ & Prol & portion & Correct $=$ & $=0.592$ & \\
\hline
\end{tabular}

Figure 19: Summary of discriminant analysis of the classification of slope movements including unfailed slopes. 


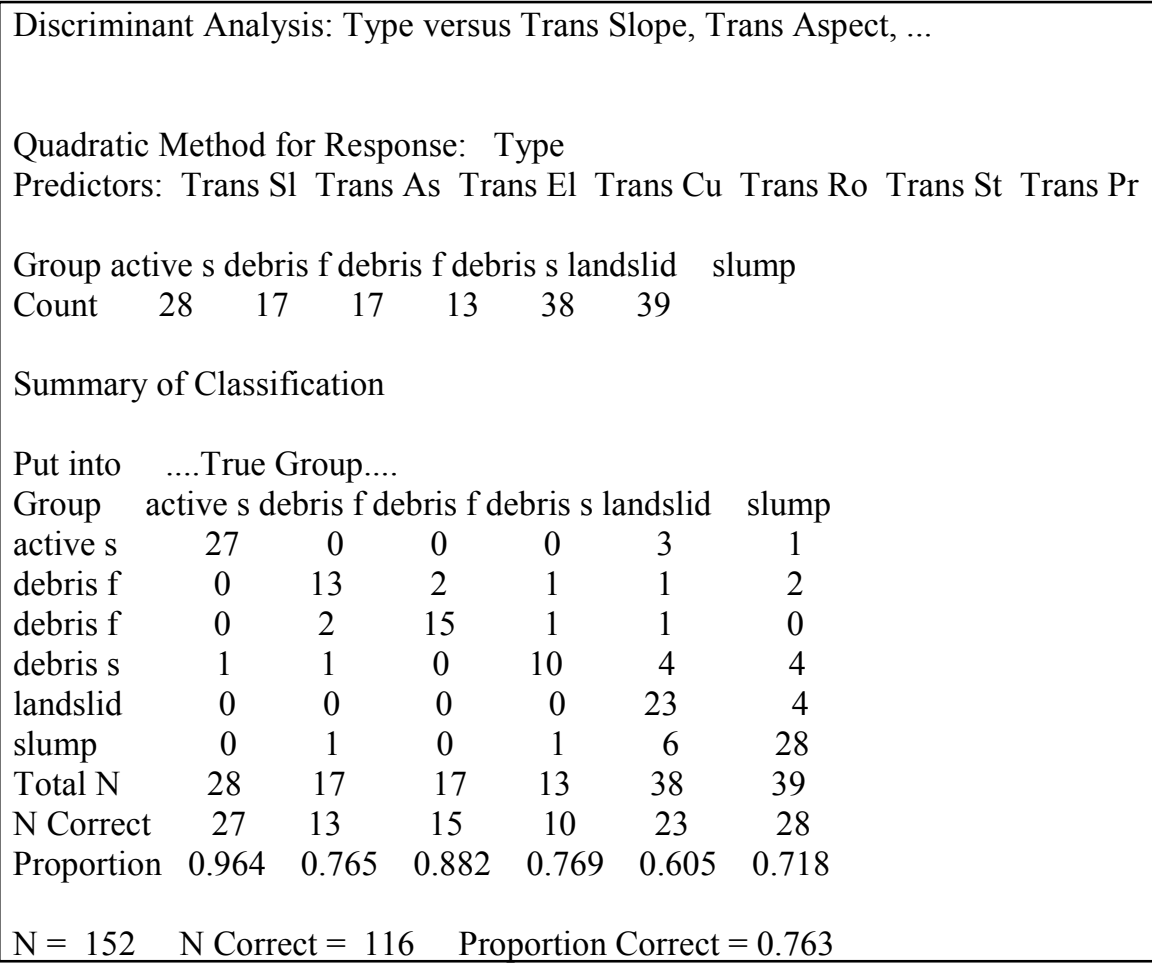

Figure 20: Summary of discriminant analysis of the different classifications of failed slopes within Horseshoe Run watershed. Only failed data was used in this analysis. 


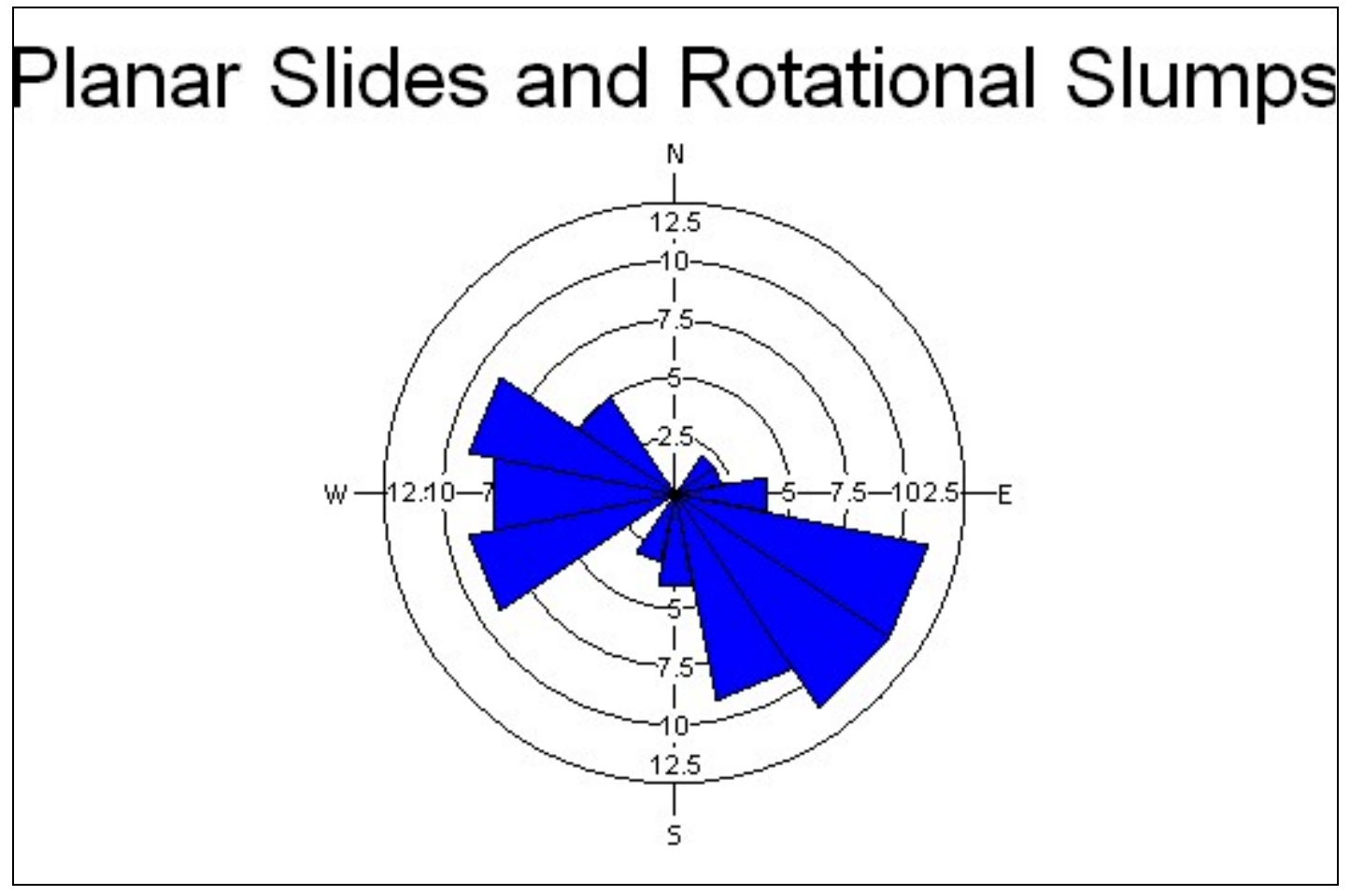

Figure 21: Rose diagrams showing the preferred aspects for planar slides and rotational slumps within Horseshoe Run watershed. 


\section{Debris Flows and Debris Fans}

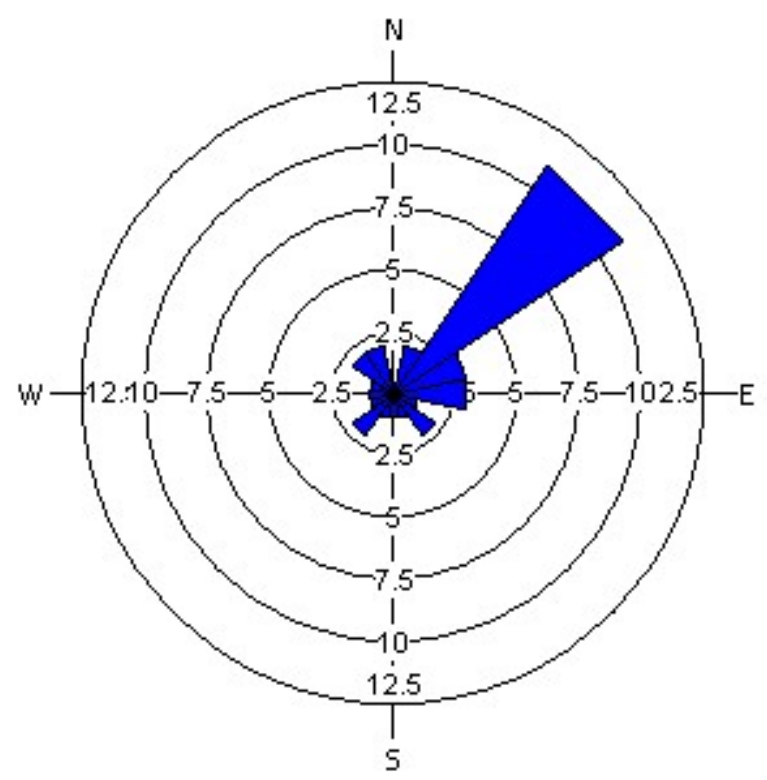

Figure 22: Rose diagram showing the preferred slope aspects for debris flows and debris fans within Horseshoe Run watershed. 


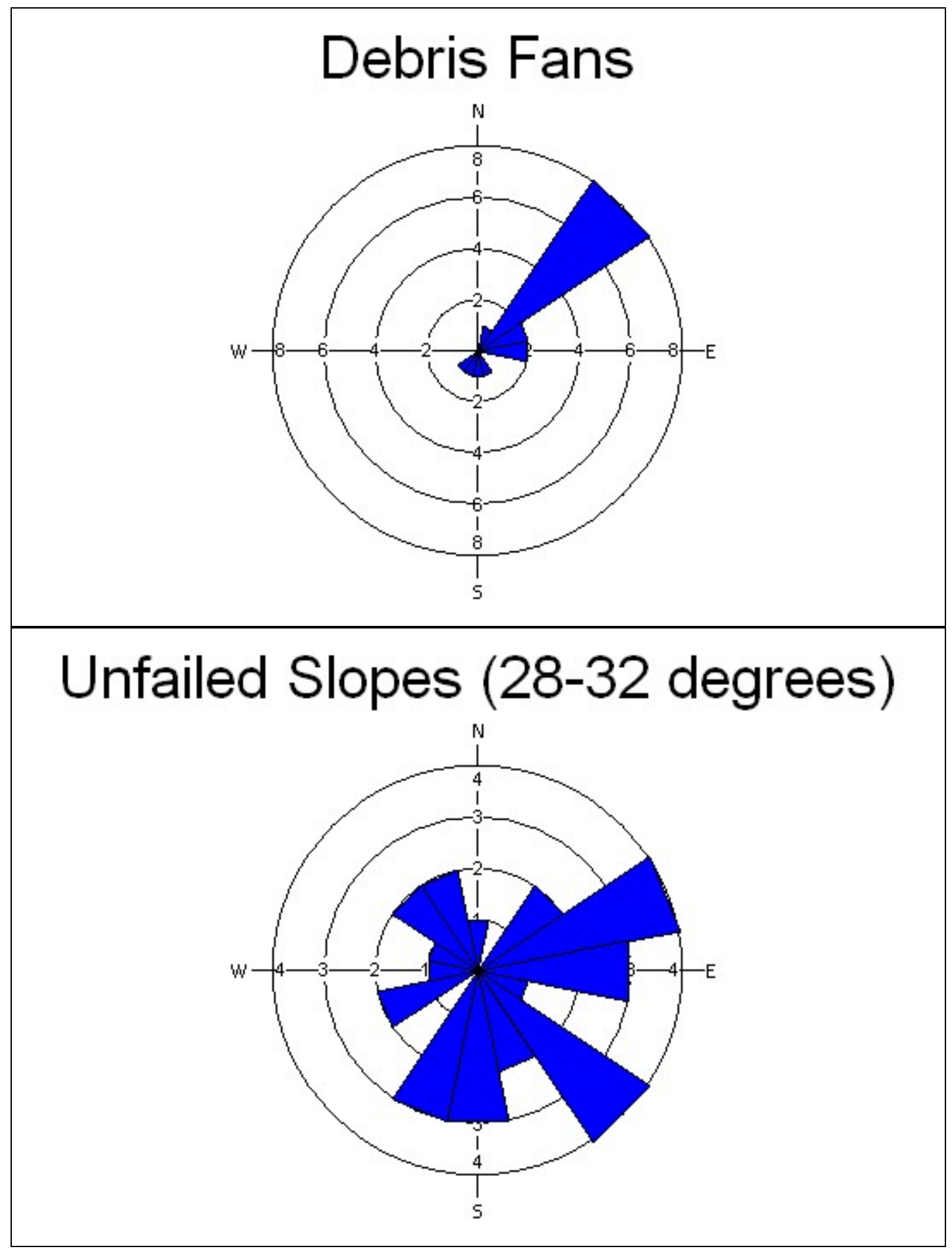

Figure 23: Rose diagrams showing the differences in aspect of debris fans and unfailed slopes with slope angles between $28-32^{\circ}$. 


\section{Landslide Susceptibility Map:}

The results from the discriminant analysis comparing all failed and unfailed slopes were used to create a landslide susceptibility map for Horseshoe Run watershed. The variables used in this analysis were: slope angle, slope aspect, elevation, plan curvature, profile curvature, distance from roads, and distance from streams. The linear discriminant analysis function that was calculated by Minitab 13.30 was entered into the Raster Calculator within the Spatial Analysis Toolbar of ArcGIS 9.2. The following equation is the linear discriminant function that was calculated by Minitab 13.30 and entered into ArcGIS 9.2:

$$
F=0.492(s l)+0.014(a s)+0.107(e l)-0.275(p l)+0.031(d r)-0.02(d s)+0.163(p r)
$$

where, $s l$ is the slope angle,

as is the slope aspect,

$e l$ is the elevation,

$p l$ is the plan curvature,

$d r$ is the distance from roads,

$d s$ is the distance from streams,

$p r$ is the profile curvature.

This linear discriminant function shows that slope angle, plan curvature, and profile curvature are the three most important factors controlling the stability of the hillslopes. The Raster Calculator then produced an output which assigned each raster cell 
within the watershed a risk of failure value. These values were then reclassified as low risk, low-medium risk, medium risk, medium-high risk, and high risk.

The landslide susceptibility map identifies those areas within the watershed that have a higher risk for slope failure (Plate 3 ). Results from the susceptibility map indicate that only $6.09 \%$ of the watershed is at high risk for slope failure and that the majority of the watershed (41.62\%) is only at a medium risk for slope failure (Table 5). Visual inspection of the susceptibility map shows that the high risk areas are concentrated into a few areas within the watershed. One of the locations of concentrated high risk is located on the southern end of Backbone Mountain within the Carboniferous formations, despite most of the slope movements occurring in other locations within the Devonian formations. This false high risk area on Backbone Mountain suggests that the other variables used in this study, such as slope angle and elevation, are also very important in predicting where slope movements might occur. Additionally, variables that were not used in this study, such as lithology, are also important contributing factors in predicting locations of slope stability. The high resistivity of the Pottsville sandstone, and the fact that the Pottsville formation weathers into large boulders helps to minimize the potential risk for slope failure within this formation of Backbone Mountain. The presence of a false high landslide susceptibility on Backbone Mountain warrants further field and remote sensing analysis to determine which factors are significantly contributing to slope failure in this area.

Comparing the locations of high risk within the watershed to those locations of mapped slope movements shows a correlation between these two groups in areas underlain by Devonian rock. Although not every slope movement was initiated within a 
high risk area, no slope movement was initiated in an area less than medium risk, suggesting that the $71.3 \%$ accuracy of the discriminant analysis between failed and unfailed slopes is affecting the landslide susceptibility map. However, because the landslide susceptibility map was created objectively by using the landscape variables and multivariate statistical analyses, it can be used to make general statements about the slope stability within Horseshoe Run watershed and bring attention to certain areas that have a higher risk for slope failure. 


\begin{tabular}{|l|r|}
\hline $\begin{array}{l}\text { Landslide susceptibility } \\
\text { risk }\end{array}$ & $\begin{array}{l}\text { Proportion of area in } \\
\text { Horseshoe Run watershed (\%) }\end{array}$ \\
\hline low risk & 7.43 \\
\hline low-medium risk & 24.46 \\
\hline medium risk & 41.62 \\
\hline medium-high risk & 20.48 \\
\hline high risk & 6.09 \\
\hline
\end{tabular}

Table 5: Landslide susceptibility risk and the percentage of area within Horseshoe Run. 


\section{Conclusions:}

The statistical analyses described above show that certain types of slope movements have similar characteristics and can be classified based on those observations. Active slopes, which were accurately classified in $96.4 \%$ of cases by the discriminant function, are an obvious example. The data show that active slopes occur at sites with an average slope angle is $35.9^{\circ}$ and the average distance from streams is only $61 \mathrm{~m}$. However, having data for one type of slope movement explains only half of the story; when these means are compared to the means for the other types of slope movements; it becomes apparent that active slopes are a distinctive group from the other classifications.

Comparisons of the rose diagrams indicate that different types of slope movements have different preferred orientations. Debris flows and debris fans occurred on slopes with a northeast orientation, whereas planar slides and rotational slumps occurred on slopes with a northwest and southeast aspect. Two possible explanations for this preferred orientation may be (1) the orientation of the breached northeast-southwest anticlinal structure across the watershed, and (2) differences in microclimate between northeast and northwest facing slopes. Planar slides and rotational slumps may be utilizing the bedding planes on the limbs of the anticline as failure surfaces. Additionally, since the south facing slopes receive more solar radiation than the north facing slopes, temperatures are warmer and evapotranspiration rates are higher (Hack and Goodlett, 1960). Greater evapotranspiration rates on the south facing slopes may be another factor explaining why planar slides and rotational slumps are occurring on these slopes in lieu of other types of failures. 
Similarly, the northeast facing slopes within Horseshoe Run watershed receive the lowest amount of heating from solar radiation because they receive solar rays during morning hours when temperatures are cool, as opposed to the northwest facing slopes, which receive solar rays during afternoon when temperatures are warmer. This difference in temperature also results in lower rates of evapotranspiration, more soil moisture, and differences in vegetation, and these factors may favor debris flow initiation on northeast facing slopes.

These results suggest that there are significant differences between failed slopes and unfailed slopes, and between the different classifications of slope movements; however, the results may provide only limited information regarding the current geomorphic processes operating within Horseshoe Run watershed. Field observations, along with intensive and detailed study of the LiDAR-derived shaded relief maps, suggest that most slope movements within the watershed are not a result of recent failures. Although there are a few planar slides that exhibit a well defined head scarp, the majority of slope movements show evidence of substantial reworking by erosional or colluvial processes. Hillslope cross-sections through slope movements lack any clear significant scars or abrupt breaks in slope that would imply recent failure. In addition, most failed slopes have been revegetated and now appear stable. The relict nature of the landslides could explain the relatively moderate level of accuracy in the discriminant analyses between types of slope movements and failed and unfailed slopes.

As a result, a susceptibility model or predictive model of where future landsliding may occur based on the location of past failures may be inappropriate for Horseshoe Run watershed. Without understanding the full conditions under which these slopes failed, it 
is difficult to predict, with some accuracy, where slopes may fail in the future. Conditions such as climate, vegetation, and the corresponding geomorphic processes influencing the watershed, could have been quite different 10,000 or more years ago.

Historic records from local residents also indicate that landslides and debris flows have not been a common geologic hazard in the past 100 years. Fansler (1962) reported that a large precipitation event in 1888 produced the second most damaging flood event in Tucker County history and reported large slope failures occurring on Backbone Mountain near the town of Hendricks, but the heavy precipitation event that created the 1985 flood on the Cheat River left no large documented landslides within Horseshoe Run watershed despite the fact that landslides and debris flows were well documented in several areas of West Virginia and Virginia (Jacobson, 1991; Colucci et al., 1991; Jacobson et al., 1991).

Without radiocarbon dates or other Quaternary dating methods on the slope movements within Horseshoe Run watershed, nothing can be said with certainty about when the failures occurred. One of the possibilities is that the slope failures occurred under a different climate, dominated by a different set of geomorphic processes. During the Wisconsinan glacial event, climate in the Appalachian Highlands and Interior Highlands, south of the glacial limit, was significantly different than it is today (Clark and Ciolkosz, 1988). Temperatures in July may have been 5 to $15 \mathrm{C}^{\circ}$ lower, and large areas in the Appalachian would have been above the forest limit; these cooler climatic conditions resulted in periglacial processes and landforms (Clark and Ciolkosz, 1988). Periglacial processes produce heavy amounts of colluvium through frost action, and create features such as boulder streams and boulder fields (Clark and Ciolkosz, 1988). 
Under these conditions, thick amounts of coarse colluvium would have been created and stored in hillslope hollows. As the climate warmed and greater precipitation intensity was introduced, those thick colluvial deposits would have been flushed downslope as either debris flows or landslides (Kochel, 1987).

Similar observations and models have been created for the central Blue Ridge of Virginia (Kochel and Johnson, 1984; Kochel, 1987; Eaton et al., 2003). In June 1995, more than 1000 slope failures occurred as a result of a heavy precipitation event in the Blue Ridge Mountains. The slope movements, mostly debris flows, incised into previously deposited debris flows and stream channels, exposing the Quaternary stratigraphy (Eaton et al., 2003). Pollen collected from the stratigraphy, along with radiometric dating, was used to determine the frequency of debris flows in the region. Eaton et al. (2003) calculated from the measured dates that debris flow activity recurred on average every 2500 years, and has been intermittently active since 25,000 YBP. The 2500 year recurrence interval suggests that once a debris flow occurs, a period of colluviation must occur in order to reload the hillslope hollows (Hack and Goodlett, 1960).

Combining these models of colluviation rates and frequency of debris flows can help to explain a possible scenario for Horseshoe Run watershed. The climate near the end of the Pleistocene most likely resulted in higher colluviation rates which loaded hillslope hollows with an abundant supply of sediment, and as the climate began to warm during the early Holocene, greater amounts of precipitation resulted in debris flow activity that flushed out the hollows. The warmer climatic regime during the Holocene 
also resulted in lower colluviation rates and variations in the style of precipitation within this region of the Appalachian Mountains (Hirshboeck, 1991).

Based upon field observations and study of LiDAR-derived shaded relief maps, combined with the evidence of paleoperiglacial landforms (boulder fields and boulder streams), slope movements within Horseshoe Run watershed appear to be relict from a different, cooler climate regime that would have been operating near the end of the Pleistocene or early Holocene. A late Pleistocene or early Holocene age precludes logging within the watershed as a cause of the slope movements. In addition, the logging roads within the watershed cross-cut the slope movements, further suggesting that the logging operations did not cause the slope failures to occur. Considering the vast amount of logging roads, and the fact that logging operations had been occurring since the late 1800 's, it is possible that many of the roads visible on the LiDAR-shaded relief maps are over 100 years old. If these logging roads are cross-cutting the landslides, then this implies that the landslides are at least older than the logging roads.

Further evidence that the landslides are relict comes from field observations of the slope movements. The fact that many of the slope movements appear to have been heavily reworked and revegetated with large trees suggests that failure may have occurred under conditions that are different from today. Since frequency and time are important factors in predictive models, without knowing when the landslides occurred precludes the creation of a predictive landslide initiation model. However, the data collected for the different classifications of slope movements do provide evidence that the characteristics of the landscape contribute to the type of failure that is likely to occur. 


\section{Discussion of Fluvial Instability on Horseshoe Run:}

A good approach to assess the dynamic condition of fluvial systems is landscape sensitivity analysis (Downs and Gregory, 1994). This type of analysis, in combination with other geomorphic assessments conducted for the entire watershed, may provide information pertaining to the equilibrium state of the system. This method is far superior to the Rosgen approach for stream restoration as currently practiced because without a comprehensive geomorphic assessment of the watershed, restoration practices could have limited success, or worse has a detrimental effect. To assess the fluvial condition of Horseshoe Run, the concepts of landscape sensitivity and hillslope-channel coupling can be utilized to provide a watershed scale assessment.

Landscape sensitivity was first introduced by Brunsden and Thornes (1979), and gave a definition as "the likelihood that a given change in the controls of a system will produce a sensible, recognizable, and persistent response”. Brunsden and Thornes address many issues concerning geomorphic stability, including transient behavior caused by perturbations, either internal or external, and the proximity of the system to geomorphic thresholds. Since its introduction, many interpretations of sensitivity have been given. A few of these interpretations are outlined by Downs and Gregory (1993):

- ratio of disturbing forces to resisting forces

- propensity for change shown as proximity to threshold conditions

- ability to recover from change

- a complex combination of all of the above.

Based on the results of the landscape sensitivity analysis, landscapes can be classified as either insensitive, also referred to as robust, or sensitive (Brunsden and 
Thornes, 1979). Robust landscapes are stable in that they dampen the effects of perturbations, because of controlling resistances with the ability to minimize disturbance and easily restore the system to its original state through feedback mechanisms (Brunsden, 1993). Sensitive landscapes differ in that they are more vulnerable to disturbances, operate near major threshold boundaries, and exhibit internal instability. In delicate landscapes, recovery to perturbations may be extremely slow or incomplete.

Sensitivity analysis requires a rather large data set, typically gathered over decades. Necessary data include longitudinal and cross-sectional stream profiles, sediment transport rates, hillslope sediment delivery rates, precipitation and temperature values, and vegetation. Data sets of this size are often not available for fluvial systems and can make watershed analysis and management extremely difficult. However, sensitivity analyses for fluvial systems can be conducted by studying the degree of coupling of the system.

Harvey (2001) provides a good definition of coupling, and delineates three states of coupling and the scales at which they may operate. Coupled systems display free transmission of energy and materials between components, not coupled systems show no linkages and are therefore considered buffered, and discoupled systems were once coupled but through geomorphic change are no longer coupled. These three degrees of coupling can operate at the zonal, reach, and hillslope-channel scales.

Harvey (2001) used the concepts of coupling to assess the sensitivity of the Howgill Fells in northwest England. Using data from a 30 year monitoring program, Harvey was able to show that the sensitivity of the study area depended on the frequency and magnitude of perturbations, specifically large floods and punctuated sediment events, 
and the ability of the system to modify those disturbances through internal coupling characteristics. Results showed that channel morphology adjusted to basally induced gullies that introduced large volumes of sediment. However, as gully development progressed, revegetation occurred, which stabilized slopes. Based on the results, Harvey concluded that the Howgill Fells is in dynamic equilibrium, yet may be operating near threshold conditions. If an event of sufficient magnitude occurred within the watershed, it may cause the system to cross that geomorphic barrier.

Important to Horseshoe Run Watershed is the degree of coupling of the system at the hillslope-channel scale. Although no long term data have been collected, certain qualitative conclusions and predictions can be made by examining channel response to sediment supply from the hillslopes, the magnitude and frequency characteristics of slope movements, and the dynamics of the coupling relationship.

Results and observations from mapping slope movements in Horseshoe Run watershed show that there is a preferential slope aspect for debris flows, which differs from the preferential slope aspect of the landslides and may be due to variations in the structural geology, vegetation, and microclimate. In many hollows, debris flows are not delivered to the tributary below, but are retained on the slope. Other debris flows in the watershed are delivered to main tributaries or Horseshoe Run directly, and show signs of heavy reworking and erosion at the distal end of the debris flow. Similarly, the landslides show situations of relatively short head scarp displacements or reworking of the landslide toe by the streams. Aggradation in this watershed is limited to low-order tributaries; however, bedrock controlled reaches occur in all orders of tributaries and Horseshoe Run, suggesting fairly competent transportation capabilities. 
Taylor and Kite (2006) studied three watersheds in the Appalachians, all underlain by the Acadian clastic wedge, which are predominately sandstones and shales. Horseshoe Run watershed is in close proximity to these three watersheds and shares similar lithologic characteristics. The three watersheds in the study were the Little River basin, the Fernow Experimental Forest, and the North Fork basin. Geomorphic analyses were carried out in all three watersheds and estimates of the percentage of valley bottom storage were calculated using a GIS.

Detailed mapping of the three watersheds showed that the Little River basin has a much wider valley bottom, produced by aggrading sediment supply, allowing for sediment storage, and the stream was mostly alluvial with very little bedrock exposed, whereas, Fernow and North Fork watersheds have v-shaped valleys with little room for sediment storage and numerous bedrock controlled reaches. Taylor and Kite (2006) attributed the unique character of the Little River basin to frequent, large sediment inputs that the fluvial system can not handle, as opposed to the diffuse style of sediment delivery that takes place in Fernow and North Fork. As a result, the Little River system is aggrading and the valley bottom is widening. This, in turn, is causing more deposition of debris fans due to the decrease in slope and stream power, and is creating a positive feedback environment.

By studying the geomorphic influence of sediment input rates and styles on valley bottoms and sediment storage capabilities, Taylor and Kite (2006) were able to assess the equilibrium of the three watersheds in their study. Using percentage of bedrock controlled reaches and aggradation as indicators, they concluded that the Little River Basin is in disequilibrium. The wide valley bottom allows for stream power to be 
distributed over a larger area, resulting in an overall decrease in the stream's transporting ability. Another result of the wide valley bottom is the discoupling of the hillslopes from the channel, which allows debris flows to be preserved as depositional fans on top of the valley terraces and adds to the aggrading system. This positive feedback is driving the system further and further away from equilibrium.

Applying these same principles to Horseshoe Run, a qualitative assessment of the state of equilibrium of the system can be made. Since Horseshoe Run has many reaches that are bedrock controlled, and the valley does not appear to be aggrading, the system can be interpreted as in equilibrium. However, aggrading reaches in some of the loworder tributaries of the watershed also suggest that Horseshoe Run watershed is still attempting to flush out large sediment inputs and move towards a more stable equilibrium. In other words, Horseshoe Run may be operating near a geomorphic threshold, and, given a large enough disturbance, the watershed may cross a geomorphic barrier, resulting in disequilibrium. Evidence of fluvial disequilibrium may include poolriffle spacings that do not follow the average 5-7 channel widths or occurrence of riffles within meander bend reaches (Leopold, Wolman, and Miller, 1964).

Although preliminary, qualitative assessments can be made based on the methods described above, the exact condition of equilibrium cannot be determined until further quantitative analyses are conducted. If ages of stratigraphically distinct debris flow events can be determined at locations in Horseshoe Run watershed, then frequency and magnitude characteristics can be calculated and the equilibrium state may be resolved. Given the limited data for the watershed, initial assessments can be carried out by looking 
at the degree of coupling between the hillslopes and channel, and the implications it may have on the sensitivity of the watershed.

Considering the data collected, the discriminant analyses performed, the field and remote sensing observations that suggest the slope movements are Late Pleistocene or early Holocene, and the concepts of landscape sensitivity and hillslope coupling mentioned above, I believe that the channel instability on Horseshoe Run is not a direct result of the slope failures. However, I believe that the slope movements are indirectly contributing to the channel instability, along with logging and deforestation of the floodplain. As settlement within the watershed occurred, the forested valley bottom would have been cleared, either by burning or clear-cutting, and converted to grazing and farmland. This change of land use would have resulted in the liberation of the legacy sediments introduced by the pre-Holocene slope movements. As a result of this increased sediment supply, the channel morphology would have changed to more of a braided system in order to increase its transporting capabilities. 


\section{Discussion of the Landslide Susceptibility Map:}

Despite evidence that the slope movements within Horseshoe Run watershed may be prehistoric, a landslide susceptibility map can still be used to understand and assess certain landscape characteristics that might be conducive for slope failures. These characteristics, which were obtained objectively using multivariate statistical analyses, provide information concerning possible locations for future concern based upon the relative level of risk determined by the linear discriminant function.

Detailed visual inspection of the landslide susceptibility map reveals that a significant percentage of higher landslide risk areas are concentrated within the upper watershed and all along Backbone Mountain. As mentioned earlier, the modeled high risk areas associated with Backbone Mountain are misleading considering the vast majority of slope movements occurred within the Devonian strata. Future landslide susceptibility models should attempt to incorporate information regarding the bedrock geology in order to de-emphasize the risk for failure on Backbone Mountain. For this study, because bedrock geology was not chosen as a landscape variable, focus for areas of concern within the watershed is limited to areas underlain by Devonian bedrock.

The areas of concern within Horseshoe Run watershed, underlain by the Devonian strata, can be used to estimate possible locations for disturbance within the watershed. These areas of concern have the potential to provide large amounts of sediment to lower reaches of the watershed. However, these sediment supply areas need to have the size potential to create a disturbance in the lower reaches of the watershed and also on the main stem of Horseshoe Run. Studies have shown that fluvial geomorphic disturbances caused by increased sediment loads from tributaries to main stems often scale with the 
ratio of the tributary to the main stem (Benda et al., 2004). In other words, larger tributaries have greater potential for morphological change in the main stem by introduction of punctuated sediments and large woody debris.

Benda et al. (2004) analyzed results from 14 published field studies that documented morphologic alterations of stream confluences caused by punctuated sediment supplies and introduced woody debris within North America. The results of Benda et al. (2004) suggest that there is a threshold ratio of tributary drainage area to main stem drainage area, below which the effects of the tributary will not be significant. This threshold indicates that debris flows originating from small tributary basins (less than $1 \mathrm{~km}^{2}$ ) will only affect main stem river basins that drain up to $50 \mathrm{~km}^{2}$ (Benda et al., 2004); these authors state that in humid environments, tributary to main stem ratios between 0.04 and 0.8 correspond to probability values of 0.6 to 0.9 that an effect will be significant.

Applying these tributary to main stem ratios, and the corresponding probability values, to Horseshoe Run watershed will help to identify areas of concern within the watershed that have the size and sediment supply potential to create disturbances within the watershed. For example, at the confluence between Wolf Run $\left(20.1 \mathrm{~km}^{2}\right)$ and Horseshoe Run $\left(48.6 \mathrm{~km}^{2}\right)$, the ratio is 0.414 (Figure 24). This tributary to main stem ratio indicates that Wolf Run has the potential to influence the stream sediment transport balance below its confluence with Horseshoe Run. Additionally, the landslide susceptibility map within the Wolf Run basin shows that a majority of the slopes are classified as medium to high risk for slope failure. Combining the high tributary to main stem ratio of 0.414 with the potential risk for many slopes within the Wolf Run basin, 
suggest that the confluence between Wolf Run and Horseshoe Run has the potential to cause significant disturbance on the main stem of Horseshoe Run.

Similarly, these concepts can be applied to the entire watershed in order to determine those locations of concern. Another location of concern is in the headwaters of Horseshoe Run. The landslide susceptibility map for this area shows high risk of slope failure and ratios of tributary to main stem are rather large. At some locations, the high risk areas are located on slopes adjacent to Horseshoe Run, indicating some level of coupling between the hillslopes and the channel, and would be a location of direct sediment supply to the stream. Another location deserving of attention is Maxwell Run (Figure 25). Although Maxwell Run is located roughly $4.5 \mathrm{~km}$ upstream from the mouth of Horseshoe Run, the drainage area of Maxwell Run is still relatively large $\left(9.4 \mathrm{~km}^{2}\right)$ and gives a tributary to main stem ratio of about 0.08 . Maxwell Run drainage basin also has many slopes classifies as medium to high risk for slope failure, and the concentrated area of high risk on Backbone Mountain drains into Maxwell Run. These high risk areas indicate large sources of sediment and therefore could have significant alterations of channel morphology downstream and at the confluence with Horseshoe Run.

These locations of concern for disturbance within Horseshoe Run watershed provide only an initial investigation into the landslide susceptibility of the watershed. Further analyses should be conducted in order to determine whether the mapped landslides within the watershed are still unstable and whether they are truly prehistoric. However, current areas of concern for slope stability within the watershed are those areas that are mapped as active slopes. These active slopes are currently failing as a result of undercutting and oversteepening by the active channels and provide a current source of coarse sediment to 
the fluvial system. 

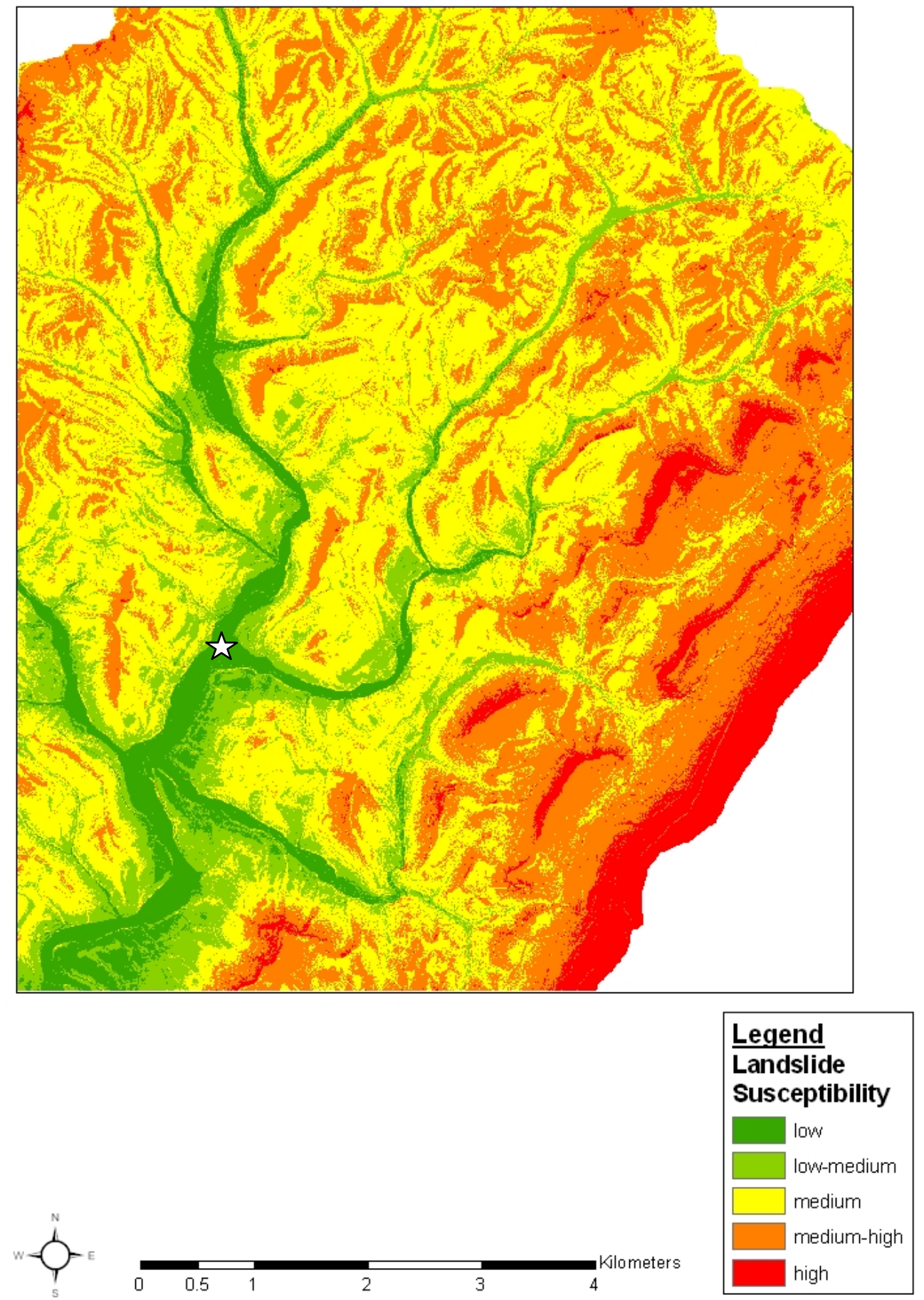

Figure 24: Landslide susceptibility map showing the confluence of Wolf Run and Horseshoe Run and the relative sizes of both drainage basins. White star shows approximate location of the confluence. Wolf Run is the tributary flowing from the east and Horseshoe Run is flowing from the north. 

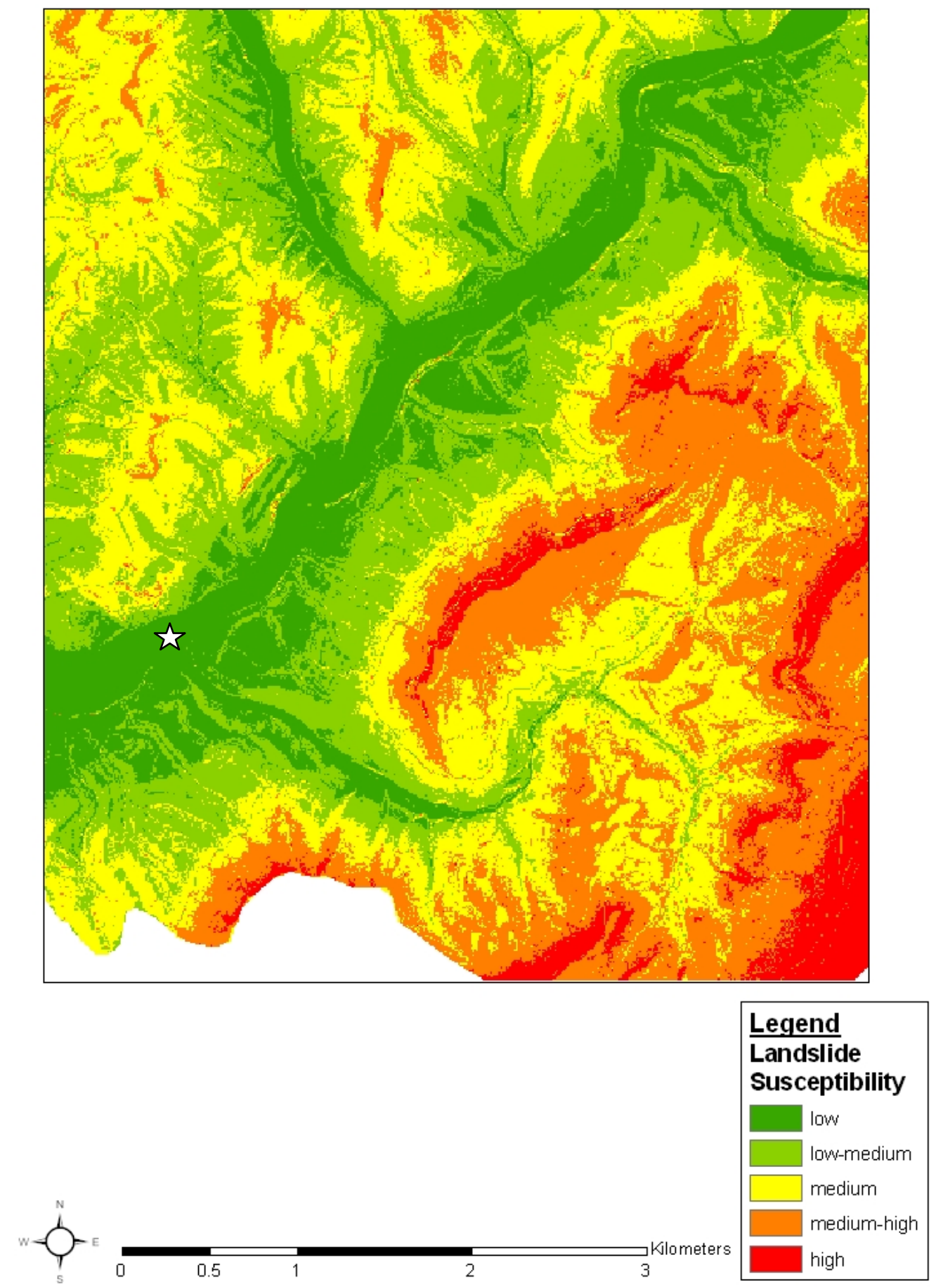

Figure 25: Landslide susceptibility map showing the location of Maxwell Run and its confluence with Horseshoe Run. White star shows approximate location of confluence. Maxwell Run is the tributary valley coming in from the southeast. 


\section{References:}

Alexander, David E., 2008, A brief survey of GIS in mass-movement studies, with reflections on theory and methods, Geomorphology, vol. 94, p. 261-267.

Bakersville, Charles A., and Ohlmacher, Gregory C., 1987, Recent slope movements in Vermont, Landslides of Eastern North America, U.S. Geological Survey Circular 1008 , p. 1-5.

Baeza, C. and Corominas, J., 2001, Assessment of shallow landslide susceptibility by means of multivariate statistical techniques, Earth Surface Processes and Landforms, vol.26, no.12, p.1251-1263.

Behling, Robert E., 1987, Slope instability in the Appalachian Plateaus Province, West Virginia: Numerous cases, numerous causes, few cures, Landslides of Eastern North America, U.S. Geological Survey Circular 1008, p. 35-36.

Benda, Lee, Poff, N. Leroy, Miller, Daniel, Dunne, Thomas, Reeves, Gordon, Pess, George, and Pollock, Michael, 2004, The network dynamics hypothesis: How channel networks structure riverine habitats, BioScience, vol. 54, no. 5, p. 413-427.

Bennett, Janette, 2007, Canaan Valley Institute, manager of GIS program, Science and Technology Division, personal communication, June, 2007.

Brooks, Andrew P., and Brierley, Gary J., 1997, Geomorphic responses of lower Bega River to catchment disturbance, 1851 - 1926, Geomorphology, vol. 18, p. 291-304.

Brunsden, Denys, 1994, Barriers to geomorphological change, Landscape Sensitivity, John Wiley and Sons, Chichester, United Kingdom, p. 7-12.

Brunsden, D., and Thornes, J.B., 1979, Landscape Sensitivity and Change, Transactions, Institute of British Geographers, vol.4, no.4, p. 463-484.

Campbell, Russell H., Varnes, David J., Fleming, Robert W., Hampton, Monty A., Prior David B., Sangrey, Dwight A., Nichols, Donald R., and Brabb, Earl E., 1985, Landslide classification for identification of mud flows and other landslides, in Campbell, Russell H., editor, Feasibility of a nationwide program for the identification and delineation of hazards from mud flows and other landslides: U.S. Geological Survey Open-File Report 85-276, p. A1-A24.

Canaan Valley Institute, Horseshoe Run in Tucker County, West Virginia, www.canaanvi.org, data taken February, 2007. 
Carrara, A., Crosta, G., and Frattini, P., 2008, Comparing models of debris-flow susceptibility in the alpine environment, Geomorphology, vol. 94, p. 353-378.

Carrara, A., Guzzetti, F., Cardinali, M., and Reichenbach, P., 1999, Use of GIS technology in the prediction and monitoring of landslide hazard, Natural Hazards, vol. 20, p. 117-135.

Carrara, A., and Pike, R., 2008, GIS technology and models for assessing landslide hazard and risk: Editorial, Geomorphology, vol. 94, p. 257-260.

Cederholm, C.J., Reid, L.M., and Salo, E.O., 1980, Cumulative effects of logging road sediment on salmonid populations in the Clearwater River, Jefferson County, Washington, Water Research Center Report 39, Conference on salmon-spawning gravel: a renewable resource in the Pacific Northwest, Washington State University, Pullman, Washington, p. 38-74.

Cenderelli, Daniel A., and Kite, J. Stephen, 1998, Geomorphic effects of large debris flows on channel morphology at North Fork Mountain, Eastern West Virginia, USA, Earth Surface Processes and Landforms, vol. 23, p. 1-19.

Clark, G. Michael, and Ciolkosz, Edward, 1988, Periglacial Geomorphology of the Appalachian Highlands and Interior Highlands South of the Glacial Border-A Review: Geomorphology, v. 1, p. 191-220.

Coelho-Netto, Ana Luiza, Avelar, Andre S., Fernandes, Manoel C., and Lacerda, Willy A., 2007, Landslide susceptibility in a mountainous geoecosystem, Tijuca Massif, Rio de Janeiro: The role of morphometric subdivision of the terrain, Geomorphology, vol. 87, issue 3, p. 120-131.

Colucci, Stephen J., Jacobson, Robert B., and Greco, Steven, 1991, Meterology of the Storm of November 3-5, 1985, in West Virginia and Virginia, Geomorphic Studies of the Storm and Flood of November 3-5, 1985, in the Upper Potomac and Cheat River Basins in West Virginia and Virginia, U.S. Geological Survey Bulletin 1981, p. B1B31.

Cordone, A.J., and Kelley, D.W., 1961, The influence of inorganic sediment on aquatic life of streams, California Department of Fish and Game, Inland Fisheries Branch, vol. 47, no. 2, p. 188-288.

Dai, F. C., Lee, C. F., 2002, Landslide characteristics and slope instability modeling using GIS, Lantau Island, Hong Kong, Geomorphology, vol.42, no.3-4, p.213-228, 15 Jan 2002.

Downing, Justin Beau, Konsoer, Kory Matthew, and Kite, James Steven, 2007, LiDAR based surficial geology mapping in comparison to more traditional methods in the 
heavily vegetated Appalachian Mountains, Geological Society of America, Abstracts with Programs, vol. 39, no. 6, p. 161.

Downs, Peter W, and Gregory, Ken J, 1994, The sensitivity of river channels in the landscape system, Landscape sensitivity, John Wiley and Sons, Chichester, United Kingdom, p. 15-29.

Duman, Tamer Y., Can, Tolga, Emre, Omer, Kecer, Mustafa, Dogan, Ahmet, Ates, Serfafettin, and Durmaz, Serap, 2005, Landslide inventory of northwestern Anatloia, Turkey, Engineering Geology, vol. 37, issues 1-2, p. 99-114.

Eaton, Scott L, Morgan, Benjamin A., Kochel, R. Craig, and Howard, Alan D. Howard, 2003, Quaternary deposits and landscape evolution of the central Blue Ridge of Virginia: Geomorphology, v. 56, p 139-154.

Environmental Systems Research Institute, Inc., 2007, ArcView GIS software, version 9.2, Redlands, CA.

Fansler, Homer Floyd, 1962, History of Tucker County, West Virginia: Parsons, W. Va., McClain Printing Company, 702 p.

Galli, M., Francesca, A., Cardinali, M., Guzzetti, F., and Reichenbach, P., 2008, Comparing landslide inventory maps, Geomorphology, vol. 94, p. 268-289.

Goodwin, Nicholas R., Coops, Nicholas C., and Culvenor, Darius S., 2006, Assessment of forest structure with airborne LiDAR and the effects of platform altitude, Remote Sensing of Environment, vol. 103, p. 140-152.

Greene, Angela, 2008, Canaan Valley Institute, Natural Resources Conservation Services liaison, personal phone conversation, March 24, 2008.

Gryta, Jeffery J., and Bartholomew, Mervin J., 1987, Frequency and susceptibility of debris avalanching induced by Hurricane Camille in central Virginia, Landslides of Eastern North America, U.S. Geological Survey Circular 1008, p. 16-17.

Guzzetti, F., Carrara, A., Cardinali, M., Reichenbach, P, 1999, Landslide hazard evaluation; a review of current techniques and their application in a multi-scale study, central Italy, Geomorphology, vol.31, no.1-4, p.181-216.

Guzzetti, F., Reichenbach, P., Cardinali, M., Galli, M., and Ardizzone, F., 2005, Probabilistic landslide hazard assessment at the basin scale, Geomorphology, vol. 72, p. 272-299.

Hack, John T., and Goodlett, John C., 1960, Geomorphology and forest ecology of a mountain region in the central Appalachians, United States Geological Survey, Professional Paper 347, $66 \mathrm{p}$. 
Harvey, A.M., 2001, Coupling between hillslopes and channels in upland fluvial systems: implications for landscape sensitivity, illustrated from the Howgill Fells, northwest England, Catena, vol.42, no.2-4, p. 225-250.

He, Y.P., Xie, H., Cui, P., Wei, F.Q., Zhong, D.L., and Gardner, J.S., 2003, GIS-based hazard mapping and zonation of debris flows in Xiaojiang Basin, southwestern China, Environmental Geology, volume 45, p. 286-289.

Hirschboeck, Katherine K., 1991, Hydrology of floods and droughts, climate and floods, United States Geological Survey, Water Supply Paper 2375, p. 67-88.

Hodgson, Michael E., and Bresnahan, Patrick, 2004, Accuracy of airborne LiDARderived elevation: empirical assessment and error budget, Photogrammetric Engineering and Remote Sensing, vol. 70, no. 3, p. 331-339.

Hoffman, Daniel F., and Gabet, Emmanuel J., 2007, Effects of sediment pulses on channel morphology in a gravel-bed river, Geological Society of America Bulletin, vol. 119, no. 1/2, p. 116-125.

Holmgren, J., Nilsson, M., and Olsson, H., 2003, Simulating the effects of LiDAR scanning angle for estimation of mean tree height and canopy closure, Can. J. Remote Sensing, vol. 29, no. 5, p. 623-632.

Hungr, O., Evans, S.G., Bovis, M.J., and Hutchinson, J.N., 2001, A review of the classification of landslides of the flow type: Environmental and Engineering Geoscience, v. 7, no. 3, p. 221-238.

Jacobson, Robert B., Cron, Elizabeth D., and McGehin, John P., 1987, Preliminary results from a study of natural slope failures triggered by the storm of November 3-5, 1985, Germany Valley, West Virginia and Virginia, Landslides of Eastern North America, U.S. Geological Survey Circular 1008, p. 11-16.

Jacobson, Robert B., Cron, Elizabeth D., and McGeehin, John P., 1989, Slope movements triggered by heavy rainfall, November 3-5, 1985, in Virginia and West Virginia,

U.S.A., Geological Society of America Special Paper 236: Landslide processes of the eastern United States and Puerto Rico, GSA 1989.

Jacobson, Robert B. et al., 1991, Landslides triggered by the storm of November 3-5, 1985, Wills Mountain Anticline, West Virginia and Virginia, Geomorphic Studies of the storm and flood of November 3-5, 1985, in the Upper Potomac and Cheat River Basins in West Virginia and Virginia, U.S. Geological Survey Bulletin 1981, p. C1C33.

Kachigan, Sam Kash, 1986, Statistical Analysis: An interdisciplinary introduction to univariate and multivariate methods, Radius Press, New York, 589 p. 
Kaller, M.D., and Hartman, K.J., 2004, Evidence of a threshold level of fine sediment accumulation for altering benthic macroinvertebrate communities, Hydrobiologia, vol. 518, p. 95-104.

Kinder, Paul, 2008, Canaan Valley Institute, LiDAR Division, personal communication.

Kish, Patrick M., 2004, Factors controlling landslide initiation as a result of July 2001 high precipitation events in a section of the lower New River Gorge, West Virginia, thesis submitted to the Eberly College of Arts and Science at West Virginia University.

Kochel, R. Craig, 1987, Holocene debris flows in central Virginia, Geological Society of America, Reviews in Engineering Geology, vol. VII, p. 139-155.

Kochel, R. Craig, and Johnson, Robert A., 1984, Geomorphology and sedimentology of humid-termperate alluvial fans, central Virginia, Sedimentology of Gravels and Conglomerates, Canadian Society of Petroleum Geologists, Memoir 10, p. 109-122.

Komac, Marko, 2006, A landslide susceptibility model using the analytical hierarchy process method and multivariate statistics in perialpine Slovenia, Geomorphology, vol. 74, issues 1-4, p. 17-28.

Konsoer, K., 2006, Landslide Risk Assessment, Horseshoe Run Watershed, West Virginia, project submitted to J.S. Kite in requirement for Geol - 493F, West Virginia University.

Korup, Oliver, 2005, Large landslides and their effect on the sediment flux in South Westland, New Zealand, Earth Surface Processes and Landforms, vol. 30, p. 305-323.

Kovach Computing Services, 2007, Oriana: circular statistics software, version 2.02e, Anglesey, Wales.

Kreutzweiser, David P., Capell, Scott S., and Good, Kevin P., 2005, Effects of fine sediment inputs from a logging road on stream insect communities: a large-scale experimental approach in a Canadian headwater stream, Aquatic Ecology, vol. 39, p. 55-66.

Latham, Rebecca, Wooten, Rick, Witt, Anne, Gillon, Ken, Douglas, Tommy, Fuemmeler, Stephen, and Bauer, Jennifer, 2007, Investigation of the Peaks Creek debris flow of September 2004 and its relationship to landslide hazard mapping in Macon County, North Carolina, 2007 Southeastern Friends of the Pleistocene Field Trip Guidebook, $35 \mathrm{p}$.

Leopold, Luna B., Wolman, M. Gordon, and Miller, John P., 1964, Fluvial Processes in Geomorphology, Dover Publications, Inc., New York, 522 p. 
Lillesand, Thomas M., Kiefer, Ralph W., and Chipman, Jonathan W., 2004, Remote Sensing and Image Interpretation, $5^{\text {th }}$ ed., John Wiley and Sons, Inc., 761 p.

Lorente, Adrian, Garcia-Ruiz, Jose M., Begueria, Santiago, and Arnaez, Jose, 2002, Factors explaining the spatial distribution of hillslope debris flows: a case study in the Flysch Sector of the central Spanish Pyrennes, Mountain Research and Development, vol. 22, no. 1, p. 32-39.

Lovell, J.L., Jupp, D.L.B., Newnham, G.J., Coops, N.C., and Culvenor, D.S., 2005, Simultation study for finding optimal LiDAR acquisition parameters for forest height retrieval, Forest Ecology and Management, vol. 214, p. 398-412.

McKean, J., Roering, J., 2004, Objective landslide detection and surface morphology mapping using high-resolution airborne laser altimetry, Geomorphology, vol. 57, issues 3-4, p. 331-351.

Michaelides, Katerina, and Wainwright, John, 2002, Modelling the effects of hillslopechannel coupling on catchment hydrological response, Earth Surface Processes and Landforms, vol. 27, p. 1441-1457.

Microsoft, Inc., 2007, Microsoft Office Excel Software, version 2007, Redman, WA.

Minitab, Inc., 2000, Minitab Statistical Software, version 13.30, State College, PA.

Muotka, Timo, Paavola, Riku, Haapala, Antti, Novikmec, Milau, and Laasonen, Pekka, 2002, Long-term recovery of stream habitat structure and benthic invertebrate communities from in-stream restoration, Biological Conservation, vol. 105, p. 243 253.

Muriuki, Peter, Vlahovic, Gordana, and Malhotta, Rakesh, 2007, Relationship between landslide geo-hazard and land use policy in western North Carolina, Geological Society of America, Abstracts with Programs, vol. 39, no. 2, p. 31.

Neary, D.G., and Swift Jr., L.W., 1987, Rainfall thresholds for triggering a debris avalanching event in the southern Appalachian Mountains, Geological Society of America, Reviews in Engineering Geology, vol. VII, p. 81-92.

Ohlmacher, G.C., and Davis, J., 2003, Using multiple logistic regression and GIS technology to predict landslide hazard in northeast Kansas, USA, Engineering Geology, Volume 69, Issues 3-4, June 2003, p. 331-343.

Outerbridge, William F., 1987, Relation between landslides and bedrock in the central Appalachian Plateaus, Landslides of Eastern North America, U.S. Geological Survey Circular 1008, p. 36-37. 
Prothero, Donald R., and Schwab, Fred, 1996, Sedimentary Geology, W.H. Freeman and Company, New York, 575 p.

Rabeni, Charles F., Doisy, Kathy E., and Zweig, Leanna D., 2005, Stream invertebrate community functional responses to deposited sediment, Aquatic Sciences, vol. 67, p. 395-402.

Rickenmann, Dieter, 1999, Empirical relationships for debris flows, Natural Hazards, vol. 19 , p. 47-77.

Ritter, Dale F., Kochel, R. Craig, and Miller, Jerry R., 2002, Process Geomorphology, $4^{\text {th }}$ edition, McGraw-Hill, New York, NY, 560 p.

Rosgen, David L, 1994, A classification of natural rivers: Catena, v. 22, p. 169-199.

Taylor, Stephen B., and Kite, J. Steven, 2006, Comparative Geomorphic Analysis of Surficial Deposits at Three Central Appalachian Watersheds: Implications for Controls on Sediment-Transport Efficiency: Journal of Geomorphology (Mountain Rivers Volume), vol. 78, no. 1-2, p. 22-43.

Theiling, Charles H., 1995, Habitat rehabilitation on the upper Mississippi River, Regulated Rivers: Research and Management, vol. 11, issue 2, p. 227-238.

United States Geological Survey, Landslide Hazards Program, landslides.usgs.gov.

Van Den Eeckhaut, M., Poesen, J., Verstraeten, G., Vanacker, V., Nyssen, J., and Moeyersons, J., 2007, Use of LiDAR-derived images for mapping old landslides under forest, Earth Surface Processes and Landforms, vol. 32, issue 5, 754-769.

Vannote, R.L., Minshall, G.W., Kummins, K.W., Sedell, J.R., and Cushing, C.E., 1980, The river continuum concept, Canadian Journal of Fisheries and Aquatic Sciences, vol. 37 , no. 1, p. 130-137.

Varnes, D.J., 1978, Slope movement types and processes, Special Report - Transportation Research Board, National Research Council, no.176, p.11-33.

Reger, David B., West Virginia Geologic Survey, 1923, County Reports, Tucker County. West Virginia GIS Technical Center, West Virginia state GIS data available for downloading, wvgis.wvu.edu.

Wieczorek, Gerald F., Eaton, Scott L., Yanosky, Thomas M., and Turner, Eric J., 2006, Hurricane-induced landslide activity on an alluvial fan along Meadow Run, Shenandoah Valley, Virginia (eastern USA), Landslides, vol. 3, no. 2, p. 95-106. 
Williams, Garnett P., and Guy, Harold P., 1973, Erosional and depositional aspects of Hurricane Camille in Virginia, 1969, U.S. Geological Survey Professional Paper, Report: P 0804, p. 80.

Wilson, John P., and Gallant, John C., 2000, Terrain Analysis: Principles and Applications, John Wiley and Sons, Inc., 479 p. 


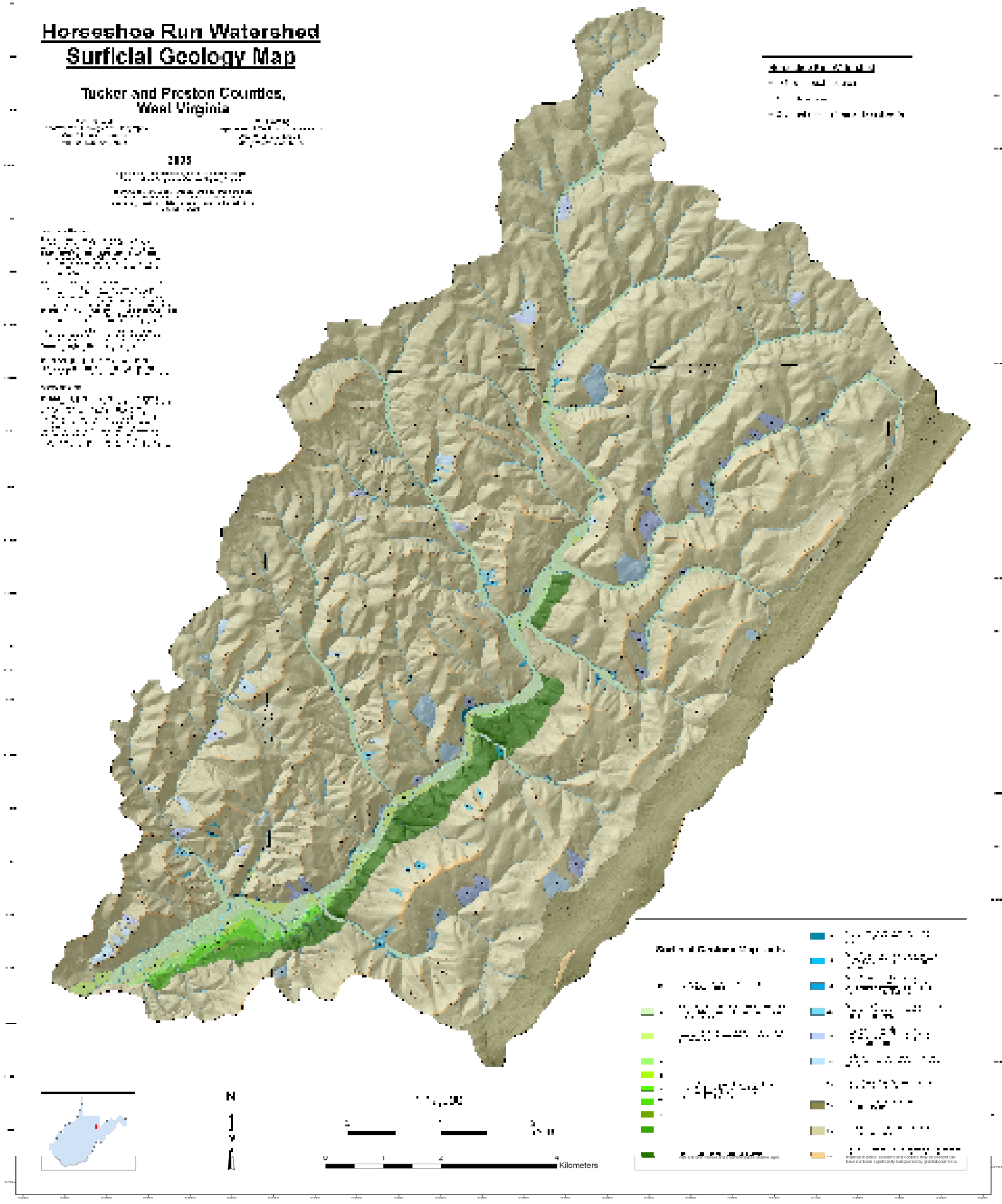

Plate 1: Surficial Geology Map of Horseshoe Run watershed, Tucker and Preston Counties, West Virginia. Map created by Downing, Konsoer, and Kite, 2008. 
Slope Movements within Horseshoe Run watershed, Tucker and Preston Counties, West Virginia

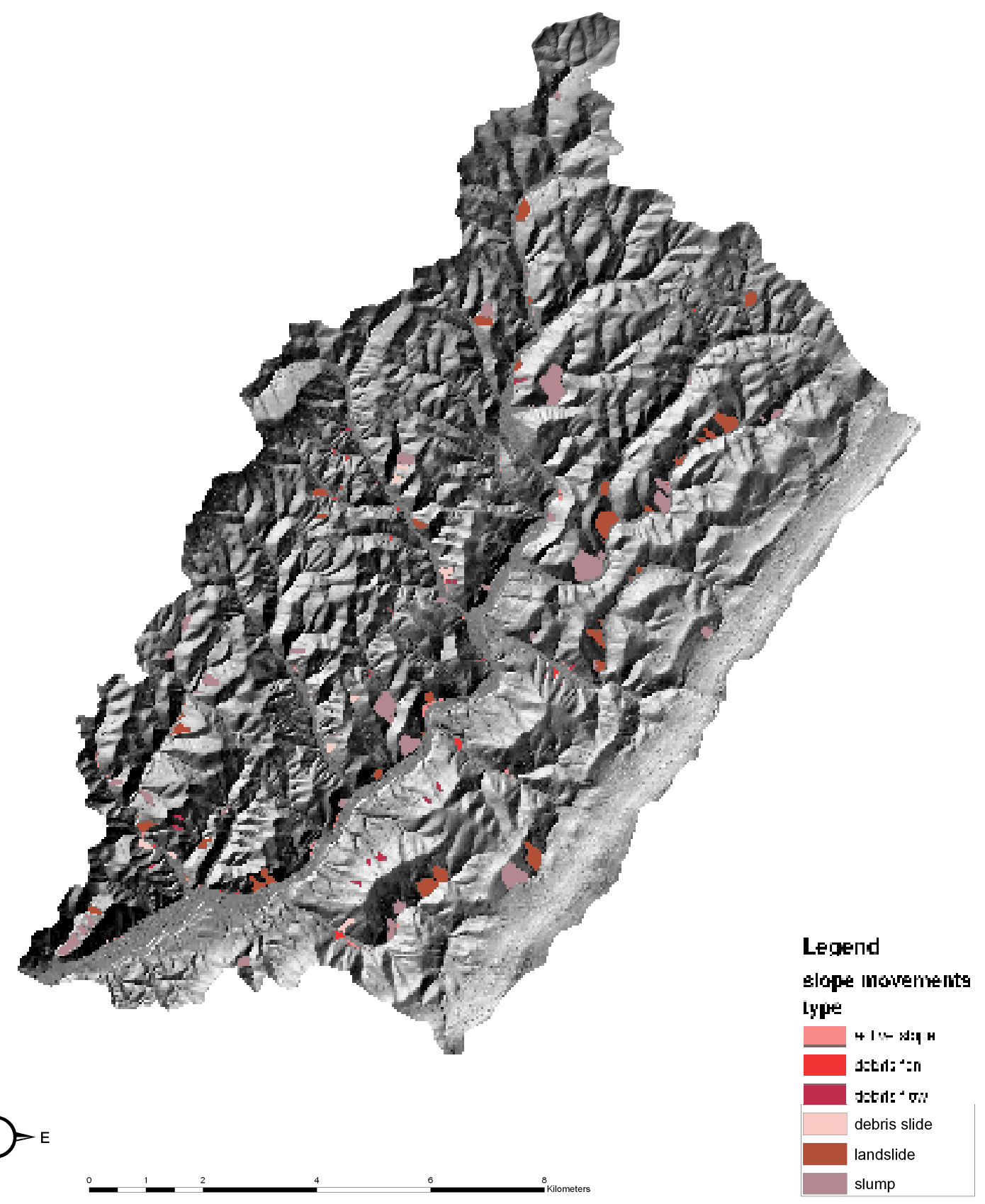

Plate 2: Landslide Inventory Map for Horseshoe Run watershed showing spatial distribution of landslides and the different types of slope movements mapped within the watershed. 


\section{Landslide Susceptibility Map for Horseshoe Run Watershed}

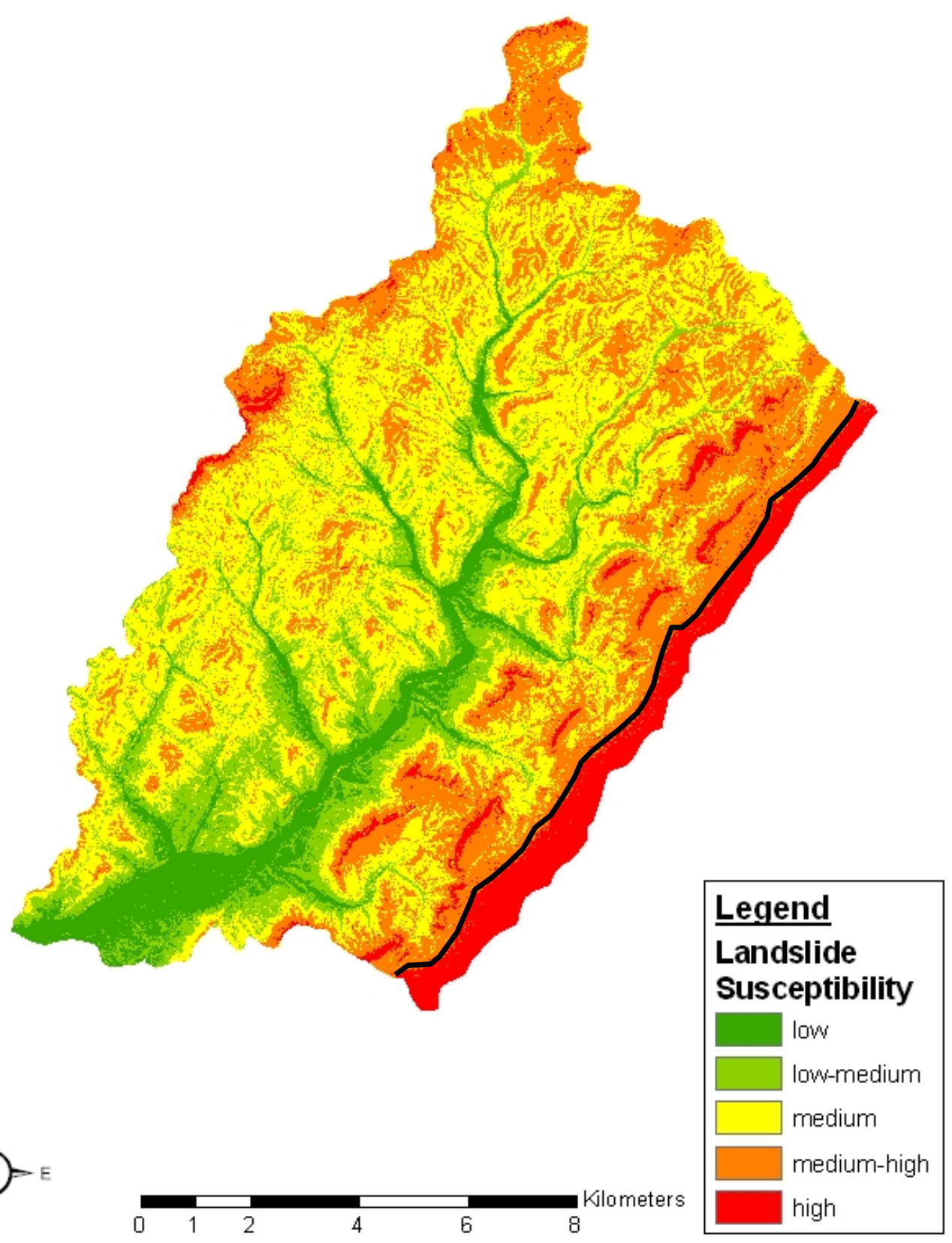

Plate 3: Landslide susceptibility map of Horseshoe Run watershed. The black line shows the approximate boundary between the Devonian and Carboniferous formations. Observations suggest that the associated risk for failure values along Backbone Mountain are heavily overestimated. 
Appendix A: Data from failed and unfailed slopes used for landslide analyses within Horseshoe Run watershed. 


\begin{tabular}{|c|c|c|c|c|c|c|c|c|c|}
\hline Value & Status & Type & $\begin{array}{l}\text { Slope } \\
\left({ }^{\circ}\right)\end{array}$ & $\begin{array}{l}\text { Aspect } \\
\left({ }^{\circ}\right)\end{array}$ & $\begin{array}{l}\text { Elevation } \\
(\mathrm{m})\end{array}$ & $\begin{array}{l}\text { Curvature } \\
\text { (radians per } \\
\text { meter) }\end{array}$ & $\begin{array}{l}\text { Dist. to } \\
\text { Roads (m) }\end{array}$ & $\begin{array}{l}\text { Dist. to } \\
\text { Streams } \\
(\mathrm{m}) \\
\end{array}$ & $\begin{array}{l}\text { Profile curvature } \\
\text { (radians per } \\
\text { meter) }\end{array}$ \\
\hline 1 & fail & debris slide & 24.80 & 243.94 & 710.77 & -0.94 & 15.89 & 285.70 & -0.11 \\
\hline 2 & fail & debris slide & 38.40 & 240.43 & 597.70 & -2.39 & 45.23 & 226.72 & -0.02 \\
\hline 3 & fail & slump & 29.07 & 284.96 & 646.30 & -0.25 & 5.12 & 355.32 & -0.39 \\
\hline 4 & fail & landslide & 18.48 & 110.48 & 547.48 & -0.48 & 84.64 & 181.97 & 2.08 \\
\hline 5 & fail & slump & 17.86 & 134.82 & 616.43 & -1.43 & 261.69 & 256.06 & 2.20 \\
\hline 6 & fail & slump & 22.24 & 93.18 & 681.51 & 0.78 & 69.31 & 315.38 & 0.37 \\
\hline 7 & fail & slump & 16.68 & 114.60 & 598.56 & -0.34 & 96.77 & 145.14 & 2.61 \\
\hline 8 & fail & landslide & 33.35 & 107.59 & 547.36 & -1.68 & 121.30 & 105.77 & 1.99 \\
\hline 9 & fail & debris fan & 12.14 & 38.50 & 614.26 & -2.63 & 209.62 & 290.37 & 0.04 \\
\hline 10 & fail & debris flow & 32.37 & 295.24 & 759.37 & 0.90 & 62.91 & 582.70 & -1.59 \\
\hline 11 & fail & debris flow & 30.41 & 333.18 & 744.33 & -1.00 & 73.65 & 654.67 & -1.27 \\
\hline 12 & fail & active slope & 27.05 & 210.78 & 610.19 & -3.37 & 1.45 & 75.41 & -0.38 \\
\hline 13 & fail & landslide & 29.35 & 142.65 & 735.99 & 1.31 & 37.26 & 326.25 & -2.32 \\
\hline 14 & fail & landslide & 17.49 & 158.24 & 751.20 & 0.23 & 86.77 & 330.40 & -0.24 \\
\hline 15 & fail & landslide & 36.17 & 89.96 & 832.98 & 1.13 & 23.00 & 281.41 & -0.41 \\
\hline 16 & fail & slump & 7.12 & 105.71 & 883.22 & -0.55 & 35.25 & 459.36 & 0.83 \\
\hline 17 & fail & active slope & 36.13 & 285.13 & 591.38 & 3.61 & 246.54 & 46.77 & -5.20 \\
\hline 18 & fail & slump & 19.05 & 157.94 & 670.84 & -2.89 & 38.93 & 187.66 & -0.04 \\
\hline 19 & fail & slump & 14.32 & 114.90 & 621.30 & 0.79 & 61.90 & 135.64 & 3.70 \\
\hline 20 & fail & debris slide & 30.00 & 35.37 & 568.85 & -0.56 & 283.00 & 93.88 & -1.65 \\
\hline 21 & fail & debris slide & 34.87 & 219.54 & 692.49 & -0.98 & 93.37 & 371.95 & -1.89 \\
\hline 22 & fail & debris fan & 27.07 & 46.20 & 702.25 & -0.50 & 78.92 & 529.25 & 0.08 \\
\hline 23 & fail & debris flow & 25.62 & 47.48 & 726.86 & 0.22 & 238.49 & 480.69 & -0.39 \\
\hline 24 & fail & active slope & 23.39 & 15.23 & 548.41 & -0.42 & 282.64 & 69.59 & -3.20 \\
\hline 25 & fail & debris flow & 28.08 & 307.88 & 778.36 & 0.16 & 1.78 & 602.65 & -0.44 \\
\hline 26 & fail & debris flow & 28.82 & 338.70 & 780.99 & 0.58 & 14.91 & 799.24 & -1.06 \\
\hline 27 & fail & debris flow & 27.81 & 309.22 & 761.48 & -2.17 & 27.52 & 586.89 & 0.27 \\
\hline 28 & fail & slump & 16.51 & 70.08 & 675.41 & -0.17 & 64.97 & 253.12 & -0.15 \\
\hline 29 & fail & landslide & 30.39 & 269.60 & 714.83 & -3.06 & 211.20 & 474.86 & -0.43 \\
\hline 30 & fail & slump & 6.69 & 53.95 & 671.88 & 2.02 & 121.63 & 356.39 & -1.62 \\
\hline 31 & fail & slump & 16.64 & 239.47 & 646.07 & -0.84 & 190.12 & 339.52 & 0.37 \\
\hline 32 & fail & slump & 8.33 & 207.11 & 594.06 & -2.12 & 254.57 & 224.22 & -0.10 \\
\hline 33 & fail & active slope & 40.41 & 141.06 & 473.72 & -1.41 & 477.36 & 66.81 & 4.42 \\
\hline 34 & fail & active slope & 26.84 & 159.86 & 475.08 & -1.13 & 471.62 & 54.83 & 5.74 \\
\hline 35 & fail & debris slide & 34.63 & 173.57 & 501.27 & 8.21 & 433.93 & 113.66 & -6.43 \\
\hline 36 & fail & debris flow & 35.04 & 40.00 & 635.38 & -0.78 & 322.63 & 394.32 & 0.81 \\
\hline 37 & fail & debris fan & 30.30 & 49.52 & 655.66 & -1.26 & 150.63 & 374.16 & 0.35 \\
\hline
\end{tabular}




\begin{tabular}{|c|c|c|c|c|c|c|c|c|c|}
\hline Value & Status & Type & $\begin{array}{l}\text { Slope } \\
\left({ }^{\circ}\right)\end{array}$ & $\begin{array}{l}\text { Aspect } \\
\left(^{\circ}\right)\end{array}$ & $\begin{array}{l}\text { Elevation } \\
(\mathrm{m})\end{array}$ & $\begin{array}{l}\text { Curvature } \\
\text { (radians per } \\
\text { meter) }\end{array}$ & $\begin{array}{l}\text { Dist. to } \\
\text { Roads (m) }\end{array}$ & $\begin{array}{l}\text { Dist. to } \\
\text { Streams } \\
\text { (m) }\end{array}$ & $\begin{array}{l}\text { Profile curvature } \\
\text { (radians per } \\
\text { meter) }\end{array}$ \\
\hline 38 & fail & debris slide & 33.00 & 221.94 & 529.14 & -0.02 & 695.79 & 183.31 & -0.42 \\
\hline 39 & fail & active slope & 34.49 & 245.02 & 503.46 & -8.67 & 395.79 & 79.99 & 2.98 \\
\hline 40 & fail & active slope & 44.25 & 169.33 & 483.61 & -1.13 & 153.08 & 41.99 & -1.51 \\
\hline 41 & fail & debris fan & 22.37 & 190.87 & 573.66 & -3.94 & 199.87 & 218.44 & -0.25 \\
\hline 42 & fail & debris fan & 33.62 & 155.78 & 565.32 & 0.50 & 590.01 & 151.43 & -0.01 \\
\hline 43 & fail & debris slide & 32.69 & 56.47 & 644.24 & -0.70 & 75.07 & 261.63 & 0.91 \\
\hline 44 & fail & debris slide & 34.47 & 33.31 & 633.34 & -1.06 & 138.55 & 251.43 & -1.26 \\
\hline 45 & fail & landslide & 33.65 & 254.69 & 537.11 & -2.92 & 153.93 & 64.36 & 8.26 \\
\hline 46 & fail & slump & 16.00 & 294.24 & 647.83 & 1.17 & 20.61 & 362.43 & 0.05 \\
\hline 47 & fail & debris flow & 35.02 & 125.86 & 680.14 & -4.22 & 263.01 & 350.93 & 0.09 \\
\hline 48 & fail & debris flow & 32.38 & 111.11 & 699.75 & -1.20 & 183.13 & 398.24 & -0.46 \\
\hline 49 & fail & landslide & 33.39 & 238.69 & 656.21 & -0.64 & 140.62 & 324.61 & 1.35 \\
\hline 50 & fail & landslide & 24.21 & 306.18 & 573.48 & -0.97 & 563.77 & 167.55 & 1.52 \\
\hline 51 & fail & active slope & 35.77 & 207.88 & 581.53 & -0.38 & 107.40 & 56.01 & -3.18 \\
\hline 52 & fail & active slope & 37.17 & 227.53 & 593.25 & -2.94 & 99.25 & 47.08 & 1.13 \\
\hline 53 & fail & slump & 30.82 & 302.38 & 665.88 & 0.00 & 323.36 & 240.00 & -0.79 \\
\hline 54 & fail & landslide & 15.30 & 273.51 & 595.96 & 2.32 & 309.51 & 107.47 & -2.58 \\
\hline 55 & fail & landslide & 21.25 & 293.90 & 690.57 & 0.34 & 288.44 & 287.76 & -0.47 \\
\hline 56 & fail & landslide & 23.07 & 292.60 & 609.55 & -1.88 & 238.43 & 86.79 & 3.04 \\
\hline 57 & fail & landslide & 22.12 & 289.93 & 613.45 & 0.28 & 136.87 & 74.20 & 1.40 \\
\hline 58 & fail & slump & 25.17 & 270.96 & 651.49 & -3.55 & 30.36 & 137.08 & 2.33 \\
\hline 59 & fail & slump & 6.18 & 150.31 & 732.68 & -0.63 & 3.21 & 298.25 & 1.66 \\
\hline 60 & fail & slump & 16.96 & 276.77 & 685.64 & 0.44 & 1.71 & 125.27 & 1.92 \\
\hline 61 & fail & slump & 17.51 & 78.84 & 693.88 & -0.90 & 231.26 & 225.31 & -0.71 \\
\hline 62 & fail & slump & 36.07 & 271.80 & 680.71 & -0.67 & 177.34 & 258.95 & 0.29 \\
\hline 63 & fail & active slope & 27.41 & 250.25 & 569.47 & -1.14 & 216.29 & 58.79 & -1.19 \\
\hline 64 & fail & debris slide & 38.21 & 256.92 & 560.44 & 2.00 & 193.65 & 168.30 & -1.44 \\
\hline 65 & fail & debris flow & 29.81 & 20.15 & 672.17 & -0.18 & 12.54 & 191.25 & -0.39 \\
\hline 66 & fail & debris fan & 26.69 & 69.51 & 633.18 & -1.89 & 44.72 & 129.72 & -0.20 \\
\hline 67 & fail & active slope & 32.28 & 129.00 & 557.97 & 0.77 & 113.47 & 78.94 & -1.74 \\
\hline 68 & fail & active slope & 26.88 & 179.28 & 543.39 & 3.11 & 166.51 & 57.07 & -2.05 \\
\hline 69 & fail & landslide & 22.44 & 109.79 & 620.22 & -1.03 & 277.96 & 219.96 & 0.39 \\
\hline 70 & fail & debris flow & 34.59 & 35.51 & 773.34 & -6.67 & 43.32 & 477.30 & 3.86 \\
\hline 71 & fail & debris flow & 26.96 & 139.92 & 743.84 & -1.75 & 15.50 & 539.64 & 0.90 \\
\hline 72 & fail & debris fan & 25.72 & 37.80 & 667.58 & -1.65 & 8.42 & 344.79 & -0.61 \\
\hline 73 & fail & debris flow & 31.56 & 215.97 & 700.21 & -1.08 & 15.04 & 256.49 & 0.47 \\
\hline 74 & fail & slump & 24.63 & 107.10 & 679.03 & 0.50 & 25.26 & 233.66 & 0.16 \\
\hline 75 & fail & slump & 25.86 & 150.93 & 643.05 & -1.01 & 10.52 & 211.54 & 0.68 \\
\hline 76 & fail & landslide & 25.55 & 90.24 & 753.69 & -0.07 & 19.00 & 340.83 & -2.91 \\
\hline
\end{tabular}




\begin{tabular}{|c|c|c|c|c|c|c|c|c|c|}
\hline Value & Status & Type & $\begin{array}{l}\text { Slope } \\
\left({ }^{\circ}\right)\end{array}$ & $\begin{array}{l}\text { Aspect } \\
\left({ }^{\circ}\right)\end{array}$ & $\begin{array}{l}\text { Elevation } \\
\text { (m) }\end{array}$ & $\begin{array}{l}\text { Curvature } \\
\text { (radians per } \\
\text { meter) }\end{array}$ & $\begin{array}{l}\text { Dist. to } \\
\text { Roads (m) }\end{array}$ & $\begin{array}{l}\text { Dist. to } \\
\text { Streams } \\
\text { (m) }\end{array}$ & $\begin{array}{l}\text { Profile curvature } \\
\text { (radians per } \\
\text { meter) }\end{array}$ \\
\hline 77 & fail & landslide & 21.49 & 119.90 & 668.74 & -2.51 & 59.60 & 114.11 & 4.03 \\
\hline 78 & fail & landslide & 10.24 & 126.56 & 660.11 & 0.26 & 39.23 & 173.16 & 2.13 \\
\hline 79 & fail & active slope & 46.09 & 230.99 & 587.26 & 0.68 & 20.70 & 33.65 & -1.62 \\
\hline 80 & fail & slump & 17.06 & 129.36 & 856.93 & 0.24 & 89.41 & 254.47 & 0.28 \\
\hline 81 & fail & landslide & 31.01 & 128.04 & 745.25 & 2.15 & 72.78 & 268.90 & -2.04 \\
\hline 82 & fail & landslide & 6.32 & 164.35 & 788.46 & -1.52 & 269.94 & 387.55 & 2.11 \\
\hline 83 & fail & landslide & 12.60 & 186.08 & 688.12 & -2.41 & 31.88 & 140.19 & 3.61 \\
\hline 84 & fail & slump & 17.25 & 160.62 & 744.11 & -0.14 & 150.28 & 165.40 & 1.12 \\
\hline 85 & fail & slump & 23.56 & 147.31 & 731.76 & 0.21 & 104.68 & 152.38 & -0.54 \\
\hline 86 & fail & slump & 22.15 & 106.07 & 712.33 & -0.90 & 35.00 & 255.20 & 2.29 \\
\hline 87 & fail & slump & 19.36 & 129.44 & 711.38 & 0.27 & 15.64 & 265.64 & 0.24 \\
\hline 88 & fail & landslide & 17.79 & 146.98 & 671.59 & 0.02 & 39.87 & 152.32 & 2.35 \\
\hline 89 & fail & landslide & 35.66 & 194.89 & 666.21 & -0.70 & 22.38 & 207.35 & 3.33 \\
\hline 90 & fail & landslide & 18.59 & 131.42 & 695.63 & -2.09 & 2.25 & 234.24 & 2.78 \\
\hline 91 & fail & landslide & 36.45 & 116.61 & 681.51 & -0.44 & 335.35 & 324.71 & 2.12 \\
\hline 92 & fail & landslide & 14.73 & 158.98 & 615.60 & -3.51 & 417.83 & 115.40 & 4.62 \\
\hline 93 & fail & slump & 5.99 & 254.10 & 723.54 & -2.50 & 435.42 & 505.62 & 4.28 \\
\hline 94 & fail & slump & 12.90 & 125.59 & 615.20 & 0.17 & 358.02 & 161.55 & 0.41 \\
\hline 95 & fail & landslide & 27.61 & 136.88 & 672.70 & -3.02 & 36.70 & 75.91 & 9.26 \\
\hline 96 & fail & slump & 30.59 & 273.62 & 649.30 & 0.20 & 204.85 & 196.29 & 0.46 \\
\hline 97 & fail & landslide & 12.73 & 141.69 & 687.40 & -0.54 & 38.60 & 103.42 & 0.34 \\
\hline 98 & fail & active slope & 42.02 & 284.02 & 618.57 & -1.96 & 196.43 & 82.88 & 4.31 \\
\hline 99 & fail & slump & 23.63 & 131.19 & 748.71 & -0.85 & 66.59 & 357.99 & 0.29 \\
\hline 100 & fail & active slope & 36.85 & 178.88 & 632.41 & -3.15 & 305.81 & 78.07 & 2.44 \\
\hline 101 & fail & active slope & 22.16 & 164.85 & 624.38 & -0.27 & 374.08 & 80.77 & -0.66 \\
\hline 102 & fail & debris flow & 32.80 & 260.52 & 741.16 & -1.16 & 266.92 & 321.03 & 0.17 \\
\hline 103 & fail & landslide & 24.05 & 288.96 & 640.53 & 1.63 & 430.27 & 143.24 & 0.30 \\
\hline 104 & fail & active slope & 27.28 & 282.32 & 616.26 & -0.87 & 234.23 & 69.85 & -3.10 \\
\hline 105 & fail & active slope & 29.85 & 246.49 & 600.11 & 0.12 & 97.14 & 48.50 & -3.82 \\
\hline 106 & fail & slump & 36.84 & 77.53 & 667.89 & 1.93 & 36.59 & 219.64 & -1.39 \\
\hline 107 & fail & active slope & 43.30 & 88.27 & 564.25 & 1.18 & 161.98 & 35.00 & -16.07 \\
\hline 108 & fail & active slope & 29.09 & 30.25 & 560.49 & 4.22 & 24.89 & 47.56 & -0.88 \\
\hline 109 & fail & slump & 28.87 & 40.38 & 575.54 & 1.26 & 34.55 & 137.83 & -0.99 \\
\hline 110 & fail & active slope & 33.33 & 249.08 & 560.16 & -2.87 & 181.74 & 40.07 & -3.70 \\
\hline 111 & fail & debris flow & 31.12 & 258.29 & 706.70 & -0.97 & 226.62 & 317.10 & 0.07 \\
\hline 112 & fail & active slope & 42.26 & 255.49 & 581.45 & -1.38 & 189.01 & 74.15 & -1.03 \\
\hline 113 & fail & debris slide & 32.74 & 268.68 & 714.40 & -0.53 & 267.52 & 350.41 & -0.17 \\
\hline 114 & fail & debris slide & 35.69 & 246.80 & 632.27 & -1.92 & 262.46 & 188.41 & 0.89 \\
\hline 115 & fail & debris fan & 29.04 & 99.07 & 682.10 & -12.84 & 18.53 & 232.51 & 7.58 \\
\hline
\end{tabular}




\begin{tabular}{|c|c|c|c|c|c|c|c|c|c|}
\hline Value & Status & Type & $\begin{array}{l}\text { Slope } \\
\left({ }^{\circ}\right)\end{array}$ & $\begin{array}{l}\text { Aspect } \\
\left(^{\circ}\right)\end{array}$ & $\begin{array}{l}\text { Elevation } \\
(\mathrm{m})\end{array}$ & $\begin{array}{l}\text { Curvature } \\
\text { (radians per } \\
\text { meter) }\end{array}$ & $\begin{array}{l}\text { Dist. to } \\
\text { Roads (m) }\end{array}$ & $\begin{array}{l}\text { Dist. to } \\
\text { Streams } \\
\text { (m) }\end{array}$ & $\begin{array}{l}\text { Profile curvature } \\
\text { (radians per } \\
\text { meter) }\end{array}$ \\
\hline 116 & fail & debris fan & 31.93 & 22.83 & 669.24 & -0.10 & 19.55 & 138.52 & -3.30 \\
\hline 117 & fail & landslide & 31.58 & 238.25 & 686.79 & -1.95 & 203.50 & 242.25 & 1.08 \\
\hline 118 & fail & debris fan & 31.78 & 34.53 & 672.79 & -8.40 & 9.97 & 218.16 & 4.13 \\
\hline 119 & fail & debris fan & 30.84 & 219.34 & 694.32 & -11.95 & 17.09 & 248.58 & 1.20 \\
\hline 120 & fail & debris fan & 24.52 & 44.94 & 682.40 & -0.57 & 1.51 & 205.21 & 2.13 \\
\hline 121 & fail & landslide & 15.56 & 242.69 & 660.93 & -3.15 & 75.36 & 187.66 & 4.77 \\
\hline 122 & fail & landslide & 17.79 & 169.17 & 688.67 & -4.47 & 23.09 & 255.20 & 6.85 \\
\hline 123 & fail & landslide & 16.61 & 303.12 & 709.34 & -2.25 & 20.20 & 157.82 & 0.87 \\
\hline 124 & fail & debris fan & 26.64 & 76.88 & 681.49 & -5.71 & 7.02 & 233.62 & 1.70 \\
\hline 125 & fail & debris fan & 22.53 & 34.51 & 675.42 & -0.27 & 3.66 & 169.66 & -5.57 \\
\hline 126 & fail & debris fan & 25.75 & 39.01 & 694.14 & -3.48 & 30.25 & 197.58 & 0.22 \\
\hline 127 & fail & debris flow & 26.06 & 77.93 & 673.93 & -1.65 & 31.49 & 268.20 & 0.16 \\
\hline 128 & fail & landslide & 15.15 & 244.49 & 647.30 & -1.54 & 41.47 & 93.25 & 4.61 \\
\hline 129 & fail & active slope & 42.74 & 236.98 & 623.77 & -4.05 & 4.58 & 37.85 & 1.48 \\
\hline 130 & fail & slump & 37.09 & 273.11 & 656.82 & -2.35 & 30.77 & 98.77 & 1.97 \\
\hline 131 & fail & landslide & 13.18 & 315.81 & 758.24 & -0.09 & 72.60 & 319.63 & 1.63 \\
\hline 132 & fail & slump & 15.84 & 263.72 & 758.69 & -0.34 & 53.95 & 273.01 & 0.20 \\
\hline 133 & fail & landslide & 7.08 & 257.23 & 698.42 & -0.32 & 155.55 & 196.44 & 0.60 \\
\hline 134 & fail & slump & 17.98 & 315.30 & 764.54 & -0.93 & 15.26 & 138.29 & 1.36 \\
\hline 135 & fail & debris fan & 17.00 & 207.25 & 747.80 & -2.73 & 144.21 & 158.38 & 0.46 \\
\hline 136 & fail & landslide & 1.97 & 304.84 & 775.45 & 0.06 & 109.92 & 247.41 & -0.35 \\
\hline 137 & fail & slump & 31.34 & 297.42 & 680.83 & -0.16 & 19.07 & 89.26 & -1.45 \\
\hline 138 & fail & debris slide & 24.40 & 285.09 & 714.50 & 0.29 & 125.97 & 253.70 & 2.81 \\
\hline 139 & fail & debris slide & 25.74 & 287.42 & 631.93 & 0.02 & 200.78 & 120.44 & 0.88 \\
\hline 140 & fail & slump & 25.06 & 249.85 & 740.21 & -0.54 & 49.39 & 285.06 & -0.23 \\
\hline 141 & fail & debris flow & 26.67 & 80.32 & 613.73 & -4.91 & 168.81 & 273.69 & 0.02 \\
\hline 142 & fail & slump & 37.15 & 117.00 & 554.18 & 1.49 & 320.99 & 114.52 & -1.21 \\
\hline 143 & fail & active slope & 53.96 & 100.05 & 519.30 & -2.64 & 242.32 & 40.09 & -2.79 \\
\hline 144 & fail & active slope & 43.53 & 112.94 & 513.14 & -3.45 & 248.84 & 59.01 & 2.02 \\
\hline 145 & fail & active slope & 23.93 & 92.75 & 538.20 & 2.90 & 276.69 & 63.35 & -7.13 \\
\hline 146 & fail & active slope & 63.06 & 108.12 & 513.45 & -1.04 & 227.27 & 24.75 & -10.34 \\
\hline 147 & fail & landslide & 17.15 & 181.39 & 610.76 & 1.99 & 84.33 & 230.04 & 4.55 \\
\hline 148 & fail & landslide & 35.97 & 180.08 & 576.98 & -4.31 & 32.93 & 265.09 & 0.61 \\
\hline 149 & fail & debris fan & 26.12 & 82.32 & 649.90 & 2.18 & 7.66 & 78.36 & 0.29 \\
\hline 150 & fail & active slope & 34.94 & 50.12 & 600.23 & -3.33 & 621.06 & 167.47 & -2.43 \\
\hline 151 & fail & slump & 33.26 & 325.45 & 593.44 & 0.47 & 405.10 & 81.55 & 4.96 \\
\hline 152 & fail & slump & 10.42 & 208.72 & 669.33 & -3.52 & 154.84 & 290.15 & 0.74 \\
\hline 153 & unfail & unfail & 30.88 & 39.21 & 595.72 & -2.40 & 190.31 & 195.79 & 0.77 \\
\hline 154 & unfail & unfail & 8.04 & 233.80 & 717.94 & -1.23 & 128.13 & 554.38 & 0.31 \\
\hline
\end{tabular}




\begin{tabular}{|c|c|c|c|c|c|c|c|c|c|}
\hline Value & Status & Type & $\begin{array}{l}\text { Slope } \\
\left({ }^{\circ}\right)\end{array}$ & $\begin{array}{l}\text { Aspect } \\
\left(^{\circ}\right)\end{array}$ & $\begin{array}{l}\text { Elevation } \\
(\mathrm{m})\end{array}$ & $\begin{array}{l}\text { Curvature } \\
\text { (radians per } \\
\text { meter) }\end{array}$ & $\begin{array}{l}\text { Dist. to } \\
\text { Roads (m) }\end{array}$ & $\begin{array}{l}\text { Dist. to } \\
\text { Streams } \\
\text { (m) }\end{array}$ & $\begin{array}{l}\text { Profile curvature } \\
\text { (radians per } \\
\text { meter) }\end{array}$ \\
\hline 155 & unfail & unfail & 28.82 & 334.94 & 660.13 & 0.48 & 115.11 & 14.15 & -2.32 \\
\hline 156 & unfail & unfail & 23.82 & 64.33 & 711.08 & -1.27 & 103.43 & 30.42 & 0.64 \\
\hline 157 & unfail & unfail & 21.31 & 188.41 & 747.55 & 1.00 & 26.27 & 412.41 & -1.40 \\
\hline 158 & unfail & unfail & 37.52 & 295.05 & 601.79 & -3.78 & 91.90 & 128.84 & 3.49 \\
\hline 159 & unfail & unfail & 9.64 & 97.89 & 717.91 & 0.21 & 26.51 & 233.60 & 0.13 \\
\hline 160 & unfail & unfail & 16.99 & 130.95 & 694.83 & 0.80 & 41.92 & 481.35 & 0.25 \\
\hline 161 & unfail & unfail & 26.88 & 342.93 & 802.90 & 0.58 & 28.77 & 122.78 & -0.37 \\
\hline 162 & unfail & unfail & 35.79 & 64.25 & 562.74 & -0.58 & 563.77 & 80.73 & -0.69 \\
\hline 163 & unfail & unfail & 28.98 & 30.87 & 730.55 & 2.13 & 21.12 & 254.66 & -2.34 \\
\hline 164 & unfail & unfail & 27.38 & 199.24 & 650.31 & 0.38 & 495.68 & 238.83 & 0.15 \\
\hline 165 & unfail & unfail & 22.11 & 239.97 & 627.37 & 1.09 & 80.17 & 101.24 & 0.34 \\
\hline 166 & unfail & unfail & 29.86 & 322.76 & 842.80 & -0.09 & 13.40 & 327.54 & -0.49 \\
\hline 167 & unfail & unfail & 20.71 & 17.32 & 696.64 & -2.14 & 115.67 & 33.91 & -0.98 \\
\hline 168 & unfail & unfail & 15.96 & 11.35 & 480.01 & 1.07 & 160.99 & 296.11 & 1.15 \\
\hline 169 & unfail & unfail & 19.02 & 298.17 & 559.54 & 0.27 & 167.43 & 350.63 & 1.45 \\
\hline 170 & unfail & unfail & 18.32 & 178.38 & 729.69 & 3.24 & 273.52 & 261.91 & -3.44 \\
\hline 171 & unfail & unfail & 21.32 & 141.78 & 649.86 & -1.13 & 20.36 & 122.09 & -0.66 \\
\hline 172 & unfail & unfail & 25.73 & 200.06 & 687.70 & -0.46 & 49.37 & 569.96 & -0.68 \\
\hline 173 & unfail & unfail & 29.45 & 322.95 & 570.98 & 0.77 & 143.56 & 65.49 & -0.28 \\
\hline 174 & unfail & unfail & 10.03 & 115.35 & 666.03 & -2.16 & 33.07 & 4.12 & 5.93 \\
\hline 175 & unfail & unfail & 53.52 & 236.52 & 529.62 & 3.55 & 6.08 & 130.33 & 2.03 \\
\hline 176 & unfail & unfail & 26.30 & 4.89 & 752.26 & 0.12 & 12.79 & 210.77 & 2.03 \\
\hline 177 & unfail & unfail & 2.77 & 254.05 & 745.77 & -0.47 & 8.39 & 188.34 & -0.48 \\
\hline 178 & unfail & unfail & 9.29 & 231.57 & 475.03 & 1.03 & 123.83 & 259.21 & -0.77 \\
\hline 179 & unfail & unfail & 16.77 & 89.34 & 767.43 & -1.02 & 29.10 & 280.76 & -1.65 \\
\hline 180 & unfail & unfail & 0.59 & 81.09 & 504.61 & -0.07 & 16.36 & 25.25 & 0.49 \\
\hline 181 & unfail & unfail & 3.87 & 209.26 & 705.78 & 1.07 & 141.37 & 31.77 & 1.54 \\
\hline 182 & unfail & unfail & 8.56 & 207.96 & 813.33 & -0.14 & 8.36 & 253.75 & 0.18 \\
\hline 183 & unfail & unfail & 20.77 & 215.02 & 573.00 & -0.04 & 155.89 & 123.62 & 0.50 \\
\hline 184 & unfail & unfail & 28.82 & 170.19 & 684.95 & 0.45 & 12.77 & 507.90 & 2.28 \\
\hline 185 & unfail & unfail & 26.72 & 107.90 & 600.91 & -1.06 & 102.30 & 60.65 & 1.26 \\
\hline 186 & unfail & unfail & 32.93 & 345.54 & 737.68 & -0.60 & 14.37 & 362.01 & -3.40 \\
\hline 187 & unfail & unfail & 23.82 & 157.39 & 676.24 & 0.25 & 20.69 & 115.84 & 0.74 \\
\hline 188 & unfail & unfail & 33.35 & 299.08 & 623.16 & 3.57 & 86.43 & 157.54 & -1.14 \\
\hline 189 & unfail & unfail & 15.01 & 311.14 & 867.40 & 1.95 & 30.80 & 449.75 & -0.74 \\
\hline 190 & unfail & unfail & 16.23 & 311.18 & 888.04 & 0.44 & 15.26 & 628.53 & -0.49 \\
\hline 191 & unfail & unfail & 29.38 & 255.10 & 621.08 & 0.61 & 93.00 & 88.67 & -0.26 \\
\hline 192 & unfail & unfail & 16.12 & 258.00 & 754.88 & 0.12 & 181.97 & 170.41 & -0.80 \\
\hline 193 & unfail & unfail & 24.83 & 50.59 & 611.90 & -1.03 & 33.95 & 23.83 & 0.91 \\
\hline
\end{tabular}




\begin{tabular}{|c|c|c|c|c|c|c|c|c|c|}
\hline Value & Status & Type & $\begin{array}{l}\text { Slope } \\
\left({ }^{\circ}\right)\end{array}$ & $\begin{array}{l}\text { Aspect } \\
\left({ }^{\circ}\right)\end{array}$ & $\begin{array}{l}\text { Elevation } \\
(\mathrm{m})\end{array}$ & $\begin{array}{l}\text { Curvature } \\
\text { (radians per } \\
\text { meter) }\end{array}$ & $\begin{array}{l}\text { Dist. to } \\
\text { Roads (m) }\end{array}$ & $\begin{array}{l}\text { Dist. to } \\
\text { Streams } \\
(\mathrm{m})\end{array}$ & $\begin{array}{l}\text { Profile curvature } \\
\text { (radians per } \\
\text { meter) }\end{array}$ \\
\hline 194 & unfail & unfail & 30.39 & 350.87 & 692.98 & 0.09 & 193.83 & 151.29 & 0.03 \\
\hline 195 & unfail & unfail & 25.89 & 91.72 & 682.30 & 0.67 & 356.56 & 177.54 & 0.03 \\
\hline 196 & unfail & unfail & 21.95 & 86.42 & 578.61 & -0.26 & 62.08 & 189.06 & 1.55 \\
\hline 197 & unfail & unfail & 21.43 & 310.72 & 942.00 & -0.08 & 26.22 & 818.58 & 0.56 \\
\hline 198 & unfail & unfail & 8.33 & 223.45 & 754.13 & -1.70 & 4.30 & 223.67 & 1.58 \\
\hline 199 & unfail & unfail & 19.78 & 269.20 & 840.83 & 0.47 & 32.06 & 485.97 & -1.26 \\
\hline 200 & unfail & unfail & 7.66 & 313.29 & 582.39 & 0.44 & 139.96 & 15.36 & 2.97 \\
\hline 201 & unfail & unfail & 21.95 & 48.68 & 701.44 & 1.21 & 46.69 & 108.74 & -0.59 \\
\hline 202 & unfail & unfail & 52.88 & 126.71 & 614.19 & 4.20 & 448.04 & 234.94 & 0.91 \\
\hline 203 & unfail & unfail & 34.83 & 70.56 & 619.54 & -2.10 & 23.15 & 47.42 & 0.16 \\
\hline 204 & unfail & unfail & 29.98 & 312.76 & 642.32 & 0.11 & 57.74 & 322.56 & 2.53 \\
\hline 205 & unfail & unfail & 18.37 & 318.64 & 765.64 & 0.29 & 84.08 & 228.26 & -0.71 \\
\hline 206 & unfail & unfail & 36.62 & 197.09 & 522.29 & -4.19 & 14.71 & 157.59 & 4.64 \\
\hline 207 & unfail & unfail & 28.85 & 87.59 & 718.81 & -0.65 & 95.00 & 293.32 & -0.13 \\
\hline 208 & unfail & unfail & 15.55 & 95.04 & 733.31 & -2.99 & 90.61 & 433.08 & 0.41 \\
\hline 209 & unfail & unfail & 18.54 & 187.98 & 732.40 & 0.77 & 39.67 & 189.71 & -0.19 \\
\hline 210 & unfail & unfail & 31.81 & 108.50 & 581.02 & -0.03 & 408.19 & 159.81 & -0.26 \\
\hline 211 & unfail & unfail & 2.83 & 237.94 & 849.06 & 0.23 & 4.86 & 643.61 & 0.13 \\
\hline 212 & unfail & unfail & 19.24 & 91.23 & 556.36 & -2.32 & 204.88 & 41.88 & 4.52 \\
\hline 213 & unfail & unfail & 30.09 & 291.30 & 619.56 & 0.66 & 81.64 & 155.66 & -0.08 \\
\hline 214 & unfail & unfail & 20.56 & 353.88 & 760.80 & 0.41 & 45.00 & 364.57 & 1.41 \\
\hline 215 & unfail & unfail & 16.11 & 227.78 & 740.84 & -0.27 & 119.54 & 268.77 & 0.07 \\
\hline 216 & unfail & unfail & 2.42 & 57.88 & 471.42 & 0.09 & 469.37 & 96.90 & 0.32 \\
\hline 217 & unfail & unfail & 23.27 & 313.78 & 577.88 & 0.34 & 195.11 & 375.44 & -0.63 \\
\hline 218 & unfail & unfail & 14.97 & 70.60 & 766.78 & 0.79 & 7.54 & 452.02 & -1.25 \\
\hline 219 & unfail & unfail & 17.89 & 319.98 & 618.20 & 2.03 & 15.17 & 310.55 & 0.20 \\
\hline 220 & unfail & unfail & 11.30 & 315.57 & 845.90 & 0.43 & 70.54 & 641.25 & -0.18 \\
\hline 221 & unfail & unfail & 13.13 & 322.29 & 738.38 & 0.63 & 166.80 & 204.90 & -1.44 \\
\hline 222 & unfail & unfail & 5.14 & 249.92 & 613.09 & -1.98 & 330.70 & 2.95 & 4.75 \\
\hline 223 & unfail & unfail & 20.09 & 9.54 & 726.77 & 2.17 & 112.10 & 62.34 & -3.50 \\
\hline 224 & unfail & unfail & 12.58 & 323.25 & 973.89 & -0.58 & 10.27 & 687.89 & 0.03 \\
\hline 225 & unfail & unfail & 27.17 & 255.91 & 649.72 & 1.36 & 228.11 & 89.03 & 0.14 \\
\hline 226 & unfail & unfail & 11.68 & 289.43 & 829.13 & 0.39 & 43.27 & 318.19 & 0.04 \\
\hline 227 & unfail & unfail & 16.95 & 42.08 & 656.14 & -0.13 & 21.66 & 46.17 & 1.20 \\
\hline 228 & unfail & unfail & 14.93 & 338.13 & 743.70 & 0.16 & 148.80 & 165.52 & -0.69 \\
\hline 229 & unfail & unfail & 1.30 & 307.11 & 823.71 & 0.08 & 99.96 & 474.81 & -0.20 \\
\hline 230 & unfail & unfail & 22.41 & 71.38 & 662.79 & -0.54 & 280.30 & 711.47 & 0.85 \\
\hline 231 & unfail & unfail & 34.22 & 23.42 & 652.38 & 0.23 & 3.66 & 585.74 & 2.77 \\
\hline 232 & unfail & unfail & 28.73 & 158.22 & 778.73 & 0.19 & 39.67 & 204.13 & -0.83 \\
\hline
\end{tabular}




\begin{tabular}{|c|c|c|c|c|c|c|c|c|c|}
\hline Value & Status & Type & $\begin{array}{l}\text { Slope } \\
\left({ }^{\circ}\right)\end{array}$ & $\begin{array}{l}\text { Aspect } \\
\left(^{\circ}\right)\end{array}$ & $\begin{array}{l}\text { Elevation } \\
(\mathrm{m})\end{array}$ & $\begin{array}{l}\text { Curvature } \\
\text { (radians per } \\
\text { meter) }\end{array}$ & $\begin{array}{l}\text { Dist. to } \\
\text { Roads (m) }\end{array}$ & $\begin{array}{l}\text { Dist. to } \\
\text { Streams } \\
(\mathrm{m})\end{array}$ & $\begin{array}{l}\text { Profile curvature } \\
\text { (radians per } \\
\text { meter) }\end{array}$ \\
\hline 233 & unfail & unfail & 11.83 & 177.20 & 750.15 & 0.92 & 9.94 & 292.32 & 1.80 \\
\hline 234 & unfail & unfail & 29.23 & 244.46 & 514.86 & -0.14 & 290.60 & 49.35 & -0.42 \\
\hline 235 & unfail & unfail & 26.50 & 325.78 & 607.31 & 0.46 & 5.85 & 453.38 & 0.50 \\
\hline 236 & unfail & unfail & 26.12 & 252.73 & 679.59 & 0.67 & 8.52 & 97.34 & -0.22 \\
\hline 237 & unfail & unfail & 21.77 & 253.92 & 635.43 & 0.71 & 65.59 & 73.52 & 1.26 \\
\hline 238 & unfail & unfail & 4.62 & 296.68 & 480.12 & 0.58 & 67.26 & 10.98 & -2.92 \\
\hline 239 & unfail & unfail & 31.25 & 78.52 & 809.87 & -0.02 & 91.08 & 29.18 & 0.72 \\
\hline 240 & unfail & unfail & 21.91 & 220.62 & 691.85 & 1.65 & 5.03 & 167.23 & -0.27 \\
\hline 241 & unfail & unfail & 13.65 & 164.58 & 746.22 & 0.26 & 179.21 & 261.60 & 0.15 \\
\hline 242 & unfail & unfail & 1.96 & 42.68 & 467.63 & 0.19 & 52.32 & 31.16 & -0.41 \\
\hline 243 & unfail & unfail & 29.98 & 325.86 & 625.34 & 1.54 & 55.08 & 57.66 & -2.08 \\
\hline 244 & unfail & unfail & 11.85 & 285.07 & 849.12 & -3.03 & 1.45 & 115.27 & -1.11 \\
\hline 245 & unfail & unfail & 11.33 & 298.67 & 794.08 & 0.41 & 95.23 & 927.91 & -0.37 \\
\hline 246 & unfail & unfail & 13.62 & 289.74 & 720.20 & 0.22 & 69.00 & 257.12 & 0.59 \\
\hline 247 & unfail & unfail & 24.63 & 44.91 & 688.06 & 0.12 & 69.40 & 282.90 & 0.59 \\
\hline 248 & unfail & unfail & 13.67 & 350.92 & 811.30 & 0.98 & 7.22 & 354.68 & -2.02 \\
\hline 249 & unfail & unfail & 12.63 & 87.94 & 711.60 & 1.02 & 116.27 & 105.81 & -3.31 \\
\hline 250 & unfail & unfail & 26.68 & 221.92 & 694.51 & 0.44 & 10.82 & 302.66 & 1.59 \\
\hline 251 & unfail & unfail & 31.37 & 228.10 & 642.79 & 0.10 & 9.60 & 129.73 & -0.02 \\
\hline 252 & unfail & unfail & 6.73 & 286.65 & 743.99 & 0.10 & 92.57 & 117.66 & -0.38 \\
\hline 253 & unfail & unfail & 20.66 & 90.30 & 771.80 & 0.14 & 128.71 & 393.66 & -5.35 \\
\hline 254 & unfail & unfail & 18.29 & 234.16 & 752.45 & 0.66 & 34.72 & 303.73 & -0.46 \\
\hline 255 & unfail & unfail & 11.80 & 216.49 & 819.57 & -0.45 & 194.54 & 97.37 & -0.13 \\
\hline 256 & unfail & unfail & 10.47 & 148.08 & 764.25 & 0.26 & 112.17 & 289.33 & -0.24 \\
\hline 257 & unfail & unfail & 27.41 & 283.96 & 594.43 & -0.54 & 53.00 & 54.67 & 0.53 \\
\hline 258 & unfail & unfail & 29.85 & 27.19 & 658.31 & -0.46 & 5.08 & 217.05 & -9.76 \\
\hline 259 & unfail & unfail & 29.36 & 94.30 & 625.86 & -0.80 & 255.30 & 192.37 & 0.48 \\
\hline 260 & unfail & unfail & 18.73 & 118.84 & 574.25 & 2.30 & 371.34 & 162.58 & -3.24 \\
\hline 261 & unfail & unfail & 11.43 & 98.75 & 857.57 & -0.04 & 30.27 & 323.96 & -0.11 \\
\hline 262 & unfail & unfail & 14.84 & 46.20 & 786.74 & 0.74 & 5.06 & 16.74 & -0.04 \\
\hline 263 & unfail & unfail & 27.18 & 146.34 & 717.59 & -1.15 & 46.14 & 359.95 & 0.22 \\
\hline 264 & unfail & unfail & 27.77 & 209.07 & 546.06 & -0.18 & 130.24 & 95.55 & -0.45 \\
\hline 265 & unfail & unfail & 19.80 & 175.06 & 684.32 & -3.19 & 148.16 & 243.00 & 15.62 \\
\hline 266 & unfail & unfail & 21.80 & 123.61 & 814.34 & -1.04 & 2.57 & 546.58 & 1.80 \\
\hline 267 & unfail & unfail & 10.14 & 273.35 & 723.51 & -0.28 & 41.26 & 188.38 & -2.59 \\
\hline 268 & unfail & unfail & 5.42 & 296.38 & 814.48 & 0.52 & 25.52 & 130.27 & -0.22 \\
\hline 269 & unfail & unfail & 21.05 & 233.94 & 600.23 & 0.53 & 88.41 & 402.49 & -0.73 \\
\hline 270 & unfail & unfail & 11.93 & 319.65 & 540.81 & 1.36 & 429.01 & 141.04 & -1.11 \\
\hline 271 & unfail & unfail & 10.67 & 134.65 & 708.92 & 0.33 & 54.13 & 556.02 & -0.05 \\
\hline
\end{tabular}




\begin{tabular}{|c|c|c|c|c|c|c|c|c|c|}
\hline Value & Status & Type & $\begin{array}{l}\text { Slope } \\
\left({ }^{\circ}\right)\end{array}$ & $\begin{array}{l}\text { Aspect } \\
\left(^{\circ}\right)\end{array}$ & $\begin{array}{l}\text { Elevation } \\
(\mathrm{m})\end{array}$ & $\begin{array}{l}\text { Curvature } \\
\text { (radians per } \\
\text { meter) }\end{array}$ & $\begin{array}{l}\text { Dist. to } \\
\text { Roads (m) }\end{array}$ & $\begin{array}{l}\text { Dist. to } \\
\text { Streams } \\
\text { (m) }\end{array}$ & $\begin{array}{l}\text { Profile curvature } \\
\text { (radians per } \\
\text { meter) }\end{array}$ \\
\hline 272 & unfail & unfail & 32.44 & 44.18 & 721.58 & 1.98 & 175.11 & 115.94 & -0.67 \\
\hline 273 & unfail & unfail & 38.33 & 274.57 & 619.88 & 2.91 & 326.47 & 101.14 & 11.51 \\
\hline 274 & unfail & unfail & 7.14 & 322.45 & 453.93 & 0.03 & 206.25 & 100.06 & -3.13 \\
\hline 275 & unfail & unfail & 21.23 & 292.70 & 727.57 & 0.32 & 31.76 & 111.01 & -0.25 \\
\hline 276 & unfail & unfail & 4.07 & 266.35 & 471.52 & 0.65 & 52.44 & 29.03 & -4.40 \\
\hline 277 & unfail & unfail & 34.79 & 271.90 & 745.46 & -0.89 & 125.15 & 93.66 & 1.43 \\
\hline 278 & unfail & unfail & 29.32 & 243.41 & 587.40 & -0.43 & 241.33 & 27.98 & -0.02 \\
\hline 279 & unfail & unfail & 20.79 & 263.56 & 715.43 & 0.09 & 242.68 & 424.10 & -0.84 \\
\hline 280 & unfail & unfail & 6.31 & 283.98 & 754.90 & -0.32 & 121.66 & 226.81 & -0.83 \\
\hline 281 & unfail & unfail & 8.84 & 312.89 & 820.90 & 1.36 & 33.42 & 216.96 & -0.20 \\
\hline 282 & unfail & unfail & 31.52 & 198.19 & 588.03 & -1.90 & 285.30 & 128.14 & -1.45 \\
\hline 283 & unfail & unfail & 13.49 & 69.64 & 584.15 & -0.42 & 6.60 & 3.63 & 3.76 \\
\hline 284 & unfail & unfail & 13.82 & 100.13 & 705.41 & 0.25 & 10.32 & 254.16 & 0.36 \\
\hline 285 & unfail & unfail & 20.79 & 122.08 & 644.90 & -1.11 & 252.96 & 25.68 & 4.43 \\
\hline 286 & unfail & unfail & 7.36 & 219.42 & 588.78 & 3.67 & 79.45 & 5.08 & -1.03 \\
\hline 287 & unfail & unfail & 16.40 & 150.68 & 802.79 & 0.03 & 59.46 & 605.18 & -0.08 \\
\hline 288 & unfail & unfail & 26.30 & 237.43 & 720.02 & 0.11 & 34.80 & 331.33 & 2.04 \\
\hline 289 & unfail & unfail & 14.32 & 243.32 & 863.83 & 2.11 & 105.14 & 424.81 & -3.26 \\
\hline 290 & unfail & unfail & 10.12 & 240.96 & 569.11 & -0.25 & 64.08 & 140.85 & 1.49 \\
\hline 291 & unfail & unfail & 32.67 & 35.39 & 541.11 & -0.04 & 129.03 & 56.90 & -0.93 \\
\hline 292 & unfail & unfail & 33.88 & 110.04 & 748.41 & -0.76 & 83.34 & 408.38 & 0.15 \\
\hline 293 & unfail & unfail & 13.98 & 79.02 & 748.37 & 0.50 & 1.83 & 32.77 & 0.71 \\
\hline 294 & unfail & unfail & 23.93 & 250.72 & 731.42 & 1.03 & 2.25 & 416.91 & 1.31 \\
\hline 295 & unfail & unfail & 22.33 & 256.16 & 707.45 & 0.24 & 27.23 & 64.35 & 0.23 \\
\hline 296 & unfail & unfail & 27.40 & 151.09 & 665.98 & -1.04 & 221.56 & 543.01 & 0.36 \\
\hline 297 & unfail & unfail & 20.64 & 152.40 & 739.51 & -0.16 & 235.80 & 255.17 & 0.16 \\
\hline 298 & unfail & unfail & 15.67 & 299.67 & 962.35 & -0.16 & 48.95 & 719.80 & 0.56 \\
\hline 299 & unfail & unfail & 18.10 & 280.52 & 803.69 & 0.18 & 67.64 & 821.65 & 0.17 \\
\hline 300 & unfail & unfail & 11.21 & 149.92 & 766.26 & -0.92 & 34.58 & 412.28 & 0.27 \\
\hline 301 & unfail & unfail & 19.11 & 112.58 & 714.06 & 2.71 & 3.33 & 401.80 & 0.31 \\
\hline 302 & unfail & unfail & 31.97 & 223.00 & 607.89 & 0.11 & 87.79 & 66.36 & -0.58 \\
\hline 303 & unfail & unfail & 15.54 & 285.76 & 751.39 & -0.04 & 61.22 & 274.46 & -0.01 \\
\hline 304 & unfail & unfail & 17.25 & 150.45 & 807.95 & 0.67 & 573.31 & 1274.88 & -0.21 \\
\hline 305 & unfail & unfail & 12.13 & 223.98 & 734.02 & -2.28 & 7.47 & 574.16 & 6.11 \\
\hline 306 & unfail & unfail & 19.69 & 273.22 & 758.27 & 0.30 & 420.50 & 411.51 & -0.92 \\
\hline 307 & unfail & unfail & 21.32 & 289.77 & 707.76 & 3.09 & 169.62 & 819.24 & -1.20 \\
\hline 308 & unfail & unfail & 8.12 & 259.65 & 974.32 & 0.77 & 2.81 & 948.36 & -1.08 \\
\hline 309 & unfail & unfail & 5.51 & 95.27 & 1004.00 & 1.87 & 47.61 & 1109.50 & -0.43 \\
\hline 310 & unfail & unfail & 13.91 & 296.80 & 838.67 & 0.01 & 151.86 & 296.14 & -0.27 \\
\hline
\end{tabular}




\begin{tabular}{|c|c|c|c|c|c|c|c|c|c|}
\hline Value & Status & Type & $\begin{array}{l}\text { Slope } \\
\left({ }^{\circ}\right)\end{array}$ & $\begin{array}{l}\text { Aspect } \\
\left(^{\circ}\right)\end{array}$ & $\begin{array}{l}\text { Elevation } \\
(\mathrm{m})\end{array}$ & $\begin{array}{l}\text { Curvature } \\
\text { (radians per } \\
\text { meter) }\end{array}$ & $\begin{array}{l}\text { Dist. to } \\
\text { Roads (m) }\end{array}$ & $\begin{array}{l}\text { Dist. to } \\
\text { Streams } \\
\text { (m) }\end{array}$ & $\begin{array}{l}\text { Profile curvature } \\
\text { (radians per } \\
\text { meter) }\end{array}$ \\
\hline 311 & unfail & unfail & 30.36 & 312.22 & 740.68 & -0.60 & 40.50 & 540.23 & 0.21 \\
\hline 312 & unfail & unfail & 27.10 & 355.03 & 739.63 & -1.08 & 65.46 & 344.72 & 0.57 \\
\hline 313 & unfail & unfail & 10.78 & 250.71 & 802.02 & 0.50 & 45.93 & 396.00 & -0.46 \\
\hline 314 & unfail & unfail & 8.62 & 215.49 & 684.22 & 2.26 & 370.18 & 1784.50 & -5.82 \\
\hline 315 & unfail & unfail & 7.97 & 58.48 & 499.08 & -0.79 & 400.74 & 12.77 & 5.65 \\
\hline 316 & unfail & unfail & 11.97 & 212.33 & 772.20 & 0.68 & 5.08 & 565.99 & -2.51 \\
\hline 317 & unfail & unfail & 31.86 & 71.67 & 684.57 & -0.94 & 198.38 & 185.22 & -0.61 \\
\hline 318 & unfail & unfail & 27.66 & 331.74 & 736.90 & 0.47 & 15.63 & 123.19 & 0.91 \\
\hline 319 & unfail & unfail & 13.30 & 12.04 & 800.13 & -0.31 & 87.15 & 307.70 & 0.40 \\
\hline 320 & unfail & unfail & 1.93 & 188.90 & 840.42 & 0.77 & 1.46 & 404.48 & -0.35 \\
\hline 321 & unfail & unfail & 14.92 & 17.72 & 663.74 & -0.75 & 1.58 & 374.74 & 1.23 \\
\hline 322 & unfail & unfail & 29.31 & 56.54 & 618.55 & -0.42 & 122.58 & 115.32 & -0.31 \\
\hline 323 & unfail & unfail & 2.63 & 151.88 & 993.19 & 0.19 & 80.98 & 1351.35 & 0.40 \\
\hline 324 & unfail & unfail & 1.88 & 154.22 & 784.31 & 0.37 & 47.33 & 148.71 & -0.86 \\
\hline 325 & unfail & unfail & 21.45 & 210.07 & 693.07 & 0.59 & 53.99 & 160.93 & -0.28 \\
\hline 326 & unfail & unfail & 22.25 & 276.25 & 639.40 & -0.70 & 7.13 & 328.79 & -0.72 \\
\hline 327 & unfail & unfail & 22.23 & 267.65 & 747.68 & 0.05 & 602.04 & 842.35 & 0.89 \\
\hline 328 & unfail & unfail & 15.25 & 328.65 & 907.54 & -0.87 & 23.96 & 579.68 & 0.02 \\
\hline 329 & unfail & unfail & 24.11 & 79.77 & 692.46 & -2.46 & 53.65 & 4.95 & 12.23 \\
\hline 330 & unfail & unfail & 9.07 & 179.26 & 731.74 & 1.80 & 139.13 & 324.45 & -0.98 \\
\hline 331 & unfail & unfail & 16.18 & 91.61 & 649.81 & 0.62 & 4.01 & 101.63 & -2.19 \\
\hline 332 & unfail & unfail & 31.43 & 270.11 & 672.22 & -0.02 & 193.88 & 122.90 & -0.18 \\
\hline 333 & unfail & unfail & 25.91 & 61.45 & 689.71 & -0.12 & 1.17 & 112.56 & 4.94 \\
\hline 334 & unfail & unfail & 12.36 & 90.64 & 784.14 & -1.18 & 1153.62 & 1733.02 & 8.30 \\
\hline 335 & unfail & unfail & 25.93 & 63.23 & 658.96 & -1.60 & 24.45 & 498.14 & 1.84 \\
\hline 336 & unfail & unfail & 32.64 & 78.76 & 640.88 & 0.32 & 54.60 & 52.77 & -1.34 \\
\hline 337 & unfail & unfail & 19.51 & 256.64 & 747.33 & -0.15 & 31.46 & 271.69 & 0.83 \\
\hline 338 & unfail & unfail & 12.37 & 51.27 & 789.38 & -0.86 & 75.23 & 413.25 & -0.39 \\
\hline 339 & unfail & unfail & 23.58 & 246.85 & 738.66 & 0.41 & 137.54 & 456.94 & 0.49 \\
\hline 340 & unfail & unfail & 2.71 & 193.96 & 448.19 & 0.17 & 772.72 & 642.02 & 0.14 \\
\hline 341 & unfail & unfail & 2.77 & 170.38 & 1012.35 & 0.47 & 235.81 & 1444.20 & 0.07 \\
\hline 342 & unfail & unfail & 8.80 & 334.75 & 873.97 & 0.54 & 51.23 & 835.88 & 0.60 \\
\hline 343 & unfail & unfail & 31.59 & 88.46 & 713.60 & 1.12 & 22.35 & 140.31 & 0.03 \\
\hline 344 & unfail & unfail & 25.57 & 170.13 & 657.91 & -0.48 & 315.32 & 252.00 & 0.18 \\
\hline 345 & unfail & unfail & 22.22 & 97.42 & 705.93 & 0.69 & 16.36 & 14.24 & -4.59 \\
\hline 346 & unfail & unfail & 10.97 & 311.17 & 574.54 & 0.48 & 205.24 & 271.83 & -0.13 \\
\hline 347 & unfail & unfail & 17.38 & 131.99 & 596.34 & -0.28 & 166.55 & 26.89 & 1.50 \\
\hline 348 & unfail & unfail & 24.02 & 243.58 & 717.73 & 1.05 & 341.56 & 211.02 & -0.91 \\
\hline 349 & unfail & unfail & 30.15 & 202.15 & 674.17 & 2.17 & 82.46 & 19.84 & -5.64 \\
\hline
\end{tabular}




\begin{tabular}{|c|c|c|c|c|c|c|c|c|c|}
\hline Value & Status & Type & $\begin{array}{l}\text { Slope } \\
\left({ }^{\circ}\right)\end{array}$ & $\begin{array}{l}\text { Aspect } \\
\left(^{\circ}\right)\end{array}$ & $\begin{array}{l}\text { Elevation } \\
(\mathrm{m})\end{array}$ & $\begin{array}{l}\text { Curvature } \\
\text { (radians per } \\
\text { meter) }\end{array}$ & $\begin{array}{l}\text { Dist. to } \\
\text { Roads (m) }\end{array}$ & $\begin{array}{l}\text { Dist. to } \\
\text { Streams } \\
(\mathrm{m})\end{array}$ & $\begin{array}{l}\text { Profile curvature } \\
\text { (radians per } \\
\text { meter) }\end{array}$ \\
\hline 350 & unfail & unfail & 21.00 & 228.37 & 640.41 & -0.68 & 135.07 & 58.77 & -0.79 \\
\hline 351 & unfail & unfail & 26.93 & 102.72 & 693.87 & -2.81 & 63.12 & 48.36 & 1.49 \\
\hline 352 & unfail & unfail & 4.59 & 157.24 & 592.61 & 0.59 & 90.96 & 16.27 & -3.73 \\
\hline 353 & unfail & unfail & 28.34 & 114.24 & 625.91 & -1.52 & 61.37 & 43.09 & -0.43 \\
\hline 354 & unfail & unfail & 24.67 & 20.59 & 634.14 & -0.93 & 744.72 & 1023.22 & 0.42 \\
\hline 355 & unfail & unfail & 2.64 & 227.69 & 646.88 & 0.04 & 20.38 & 22.54 & -0.09 \\
\hline 356 & unfail & unfail & 18.40 & 297.42 & 551.90 & 0.59 & 160.97 & 313.15 & 0.24 \\
\hline 357 & unfail & unfail & 14.03 & 295.11 & 862.53 & -0.56 & 599.77 & 1621.50 & 0.12 \\
\hline 358 & unfail & unfail & 24.04 & 273.44 & 784.71 & 0.68 & 120.23 & 608.62 & -0.29 \\
\hline 359 & unfail & unfail & 4.32 & 228.83 & 550.15 & -0.30 & 28.24 & 42.73 & 1.61 \\
\hline 360 & unfail & unfail & 0.69 & 205.99 & 442.99 & 0.46 & 324.74 & 339.08 & 0.29 \\
\hline 361 & unfail & unfail & 20.95 & 167.40 & 693.73 & -4.79 & 29.81 & 169.29 & 1.11 \\
\hline 362 & unfail & unfail & 17.23 & 313.07 & 785.59 & 0.84 & 314.95 & 1095.89 & -0.80 \\
\hline 363 & unfail & unfail & 12.23 & 269.98 & 795.29 & -0.78 & 18.86 & 440.48 & 0.82 \\
\hline 364 & unfail & unfail & 6.96 & 180.72 & 740.25 & -0.76 & 57.79 & 180.11 & 0.09 \\
\hline 365 & unfail & unfail & 30.75 & 348.63 & 639.53 & -0.50 & 104.12 & 163.25 & 0.78 \\
\hline 366 & unfail & unfail & 22.08 & 140.42 & 774.99 & 1.02 & 14.73 & 72.18 & -1.18 \\
\hline 367 & unfail & unfail & 27.36 & 146.74 & 707.05 & -0.49 & 155.15 & 141.74 & -0.15 \\
\hline 368 & unfail & unfail & 14.38 & 189.63 & 685.46 & -0.41 & 80.16 & 693.16 & 0.40 \\
\hline 369 & unfail & unfail & 21.73 & 90.13 & 743.10 & -0.72 & 11.00 & 50.50 & 1.48 \\
\hline 370 & unfail & unfail & 10.67 & 128.28 & 933.68 & 0.88 & 380.74 & 1040.70 & -0.64 \\
\hline 371 & unfail & unfail & 34.31 & 180.67 & 528.83 & 1.91 & 140.04 & 74.36 & 0.38 \\
\hline 372 & unfail & unfail & 13.53 & 292.18 & 989.21 & 0.13 & 50.35 & 755.72 & -0.22 \\
\hline 373 & unfail & unfail & 4.42 & 247.30 & 486.15 & 0.47 & 76.10 & 117.59 & 0.16 \\
\hline 374 & unfail & unfail & 19.73 & 321.93 & 941.64 & 1.77 & 125.99 & 1171.49 & -1.38 \\
\hline 375 & unfail & unfail & 21.19 & 299.88 & 670.37 & -0.41 & 13.62 & 49.83 & 0.74 \\
\hline 376 & unfail & unfail & 32.74 & 101.92 & 705.94 & 1.16 & 151.35 & 278.48 & 0.31 \\
\hline 377 & unfail & unfail & 24.05 & 295.32 & 828.32 & -0.65 & 17.36 & 590.18 & 0.88 \\
\hline 378 & unfail & unfail & 34.61 & 43.28 & 666.55 & 0.17 & 39.29 & 132.71 & -0.09 \\
\hline 379 & unfail & unfail & 32.40 & 57.88 & 702.58 & 2.10 & 17.35 & 208.79 & -1.23 \\
\hline 380 & unfail & unfail & 12.73 & 229.71 & 589.98 & 3.29 & 8.30 & 220.88 & -1.69 \\
\hline 381 & unfail & unfail & 33.62 & 254.66 & 568.03 & 2.03 & 221.59 & 66.58 & -0.43 \\
\hline 382 & unfail & unfail & 13.54 & 303.03 & 883.81 & 0.56 & 74.36 & 559.91 & -0.24 \\
\hline 383 & unfail & unfail & 8.27 & 265.14 & 1042.98 & -0.63 & 334.26 & 940.99 & -0.24 \\
\hline 384 & unfail & unfail & 26.67 & 129.54 & 709.24 & -0.40 & 15.69 & 968.65 & -4.05 \\
\hline 385 & unfail & unfail & 14.27 & 301.20 & 908.21 & 0.61 & 16.33 & 441.45 & 0.49 \\
\hline 386 & unfail & unfail & 12.89 & 299.14 & 712.74 & 0.18 & 35.31 & 415.26 & 0.85 \\
\hline 387 & unfail & unfail & 22.34 & 120.13 & 654.90 & -1.93 & 235.53 & 3.79 & 8.48 \\
\hline 388 & unfail & unfail & 31.26 & 288.47 & 630.78 & 0.59 & 259.65 & 126.73 & 0.15 \\
\hline
\end{tabular}




\begin{tabular}{|c|c|c|c|c|c|c|c|c|c|}
\hline Value & Status & Type & $\begin{array}{l}\text { Slope } \\
\left({ }^{\circ}\right)\end{array}$ & $\begin{array}{l}\text { Aspect } \\
\left({ }^{\circ}\right)\end{array}$ & $\begin{array}{l}\text { Elevation } \\
(\mathrm{m})\end{array}$ & $\begin{array}{l}\text { Curvature } \\
\text { (radians per } \\
\text { meter) }\end{array}$ & $\begin{array}{l}\text { Dist. to roads } \\
\text { (m) }\end{array}$ & $\begin{array}{l}\text { Dist. to } \\
\text { Streams } \\
\text { (m) }\end{array}$ & $\begin{array}{l}\text { Profile curvature } \\
\text { (radians per } \\
\text { meter) }\end{array}$ \\
\hline 389 & unfail & unfail & 19.89 & 143.80 & 777.40 & -0.05 & 24.84 & 419.95 & -0.04 \\
\hline 390 & unfail & unfail & 47.21 & 328.40 & 512.99 & 0.29 & 49.70 & 92.19 & -1.41 \\
\hline 391 & unfail & unfail & 0.73 & 140.62 & 730.57 & 0.08 & 45.17 & 649.90 & -0.10 \\
\hline 392 & unfail & unfail & 17.36 & 268.82 & 640.41 & 0.12 & 21.52 & 68.31 & 1.43 \\
\hline 393 & unfail & unfail & 15.17 & 127.24 & 639.68 & -6.39 & 56.38 & 78.30 & 8.14 \\
\hline 394 & unfail & unfail & 8.57 & 206.77 & 612.56 & 2.47 & 772.46 & 115.66 & -1.72 \\
\hline 395 & unfail & unfail & 4.06 & 235.79 & 577.96 & 2.77 & 338.65 & 7.49 & -3.49 \\
\hline 396 & unfail & unfail & 26.82 & 316.32 & 509.80 & 0.65 & 35.41 & 134.75 & 0.77 \\
\hline 397 & unfail & unfail & 7.23 & 103.06 & 1015.91 & -0.14 & 111.26 & 1140.10 & 0.59 \\
\hline 398 & unfail & unfail & 23.95 & 32.35 & 769.72 & -0.16 & 15.60 & 192.44 & -0.88 \\
\hline 399 & unfail & unfail & 19.19 & 211.91 & 748.66 & 1.86 & 9.22 & 204.97 & -0.73 \\
\hline 400 & unfail & unfail & 17.85 & 165.50 & 752.42 & 0.99 & 726.73 & 1553.01 & -0.35 \\
\hline 401 & unfail & unfail & 36.30 & 163.24 & 647.85 & -0.16 & 112.39 & 371.53 & -1.48 \\
\hline 402 & unfail & unfail & 32.71 & 39.06 & 665.32 & 1.09 & 454.51 & 1163.18 & -1.16 \\
\hline 403 & unfail & unfail & 7.80 & 308.41 & 500.26 & 1.05 & 941.58 & 1211.75 & -1.32 \\
\hline 404 & unfail & unfail & 17.30 & 124.19 & 592.55 & 0.00 & 61.64 & 111.46 & -0.49 \\
\hline 405 & unfail & unfail & 14.21 & 174.93 & 775.67 & -4.13 & 12.08 & 530.78 & 1.43 \\
\hline 406 & unfail & unfail & 13.94 & 113.58 & 697.27 & -0.43 & 14.55 & 599.79 & -0.13 \\
\hline 407 & unfail & unfail & 26.87 & 336.98 & 616.50 & -0.31 & 2.30 & 227.60 & -0.13 \\
\hline 408 & unfail & unfail & 7.48 & 181.05 & 785.72 & 2.39 & 64.54 & 305.69 & -1.07 \\
\hline 409 & unfail & unfail & 26.09 & 246.27 & 606.63 & 0.87 & 1056.02 & 1334.09 & 0.24 \\
\hline 410 & unfail & unfail & 6.12 & 323.41 & 500.96 & -0.13 & 416.20 & 95.99 & 0.33 \\
\hline 411 & unfail & unfail & 28.20 & 148.08 & 742.84 & 0.97 & 3.52 & 227.74 & -1.57 \\
\hline 412 & unfail & unfail & 21.21 & 276.28 & 681.96 & -0.35 & 9.43 & 221.81 & 0.00 \\
\hline 413 & unfail & unfail & 19.10 & 187.72 & 639.39 & 0.22 & 50.24 & 225.26 & -0.07 \\
\hline 414 & unfail & unfail & 24.31 & 340.29 & 777.37 & -0.04 & 176.58 & 113.02 & 0.60 \\
\hline 415 & unfail & unfail & 9.33 & 209.01 & 819.90 & -0.14 & 18.90 & 76.90 & -0.02 \\
\hline 416 & unfail & unfail & 16.63 & 312.96 & 639.01 & 0.13 & 119.05 & 367.31 & -1.49 \\
\hline 417 & unfail & unfail & 16.01 & 117.43 & 663.60 & -0.25 & 22.40 & 73.38 & -0.36 \\
\hline 418 & unfail & unfail & 26.16 & 99.82 & 617.65 & 0.61 & 11.24 & 450.47 & 0.53 \\
\hline 419 & unfail & unfail & 8.37 & 339.64 & 516.94 & 0.71 & 268.01 & 179.12 & -0.20 \\
\hline 420 & unfail & unfail & 30.95 & 209.28 & 642.58 & 0.17 & 112.09 & 450.55 & -0.07 \\
\hline 421 & unfail & unfail & 3.03 & 245.62 & 562.93 & 1.04 & 305.14 & 37.82 & 0.72 \\
\hline 422 & unfail & unfail & 21.78 & 319.88 & 714.79 & -0.27 & 61.28 & 961.07 & -0.07 \\
\hline 423 & unfail & unfail & 5.17 & 318.54 & 873.29 & 0.26 & 258.95 & 247.06 & -1.02 \\
\hline 424 & unfail & unfail & 10.40 & 143.80 & 798.11 & 0.41 & 191.32 & 54.59 & -0.15 \\
\hline 425 & unfail & unfail & 10.50 & 9.53 & 777.30 & 0.24 & 13.46 & 225.19 & -0.59 \\
\hline 426 & unfail & unfail & 32.12 & 22.47 & 711.46 & -0.03 & 404.81 & 109.31 & 2.17 \\
\hline 427 & unfail & unfail & 25.94 & 267.68 & 700.83 & -0.34 & 157.11 & 44.98 & 0.94 \\
\hline
\end{tabular}




\begin{tabular}{|c|c|c|c|c|c|c|c|c|c|}
\hline Value & Status & Type & $\begin{array}{l}\text { Slope } \\
\left({ }^{\circ}\right)\end{array}$ & $\begin{array}{l}\text { Aspect } \\
\left(^{\circ}\right)\end{array}$ & $\begin{array}{l}\text { Elevation } \\
(\mathrm{m})\end{array}$ & $\begin{array}{l}\text { Curvature } \\
\text { (radians per } \\
\text { meter) }\end{array}$ & $\begin{array}{l}\text { Dist. to } \\
\text { Roads (m) }\end{array}$ & $\begin{array}{l}\text { Dist. to } \\
\text { Streams } \\
(\mathrm{m})\end{array}$ & $\begin{array}{l}\text { Profile curvature } \\
\text { (radians per } \\
\text { meter) }\end{array}$ \\
\hline 428 & unfail & unfail & 29.29 & 137.53 & 622.31 & 0.29 & 18.09 & 74.81 & 1.43 \\
\hline 429 & unfail & unfail & 26.64 & 42.60 & 608.28 & -0.10 & 11.84 & 71.02 & 0.72 \\
\hline 430 & unfail & unfail & 28.69 & 303.78 & 838.15 & -0.27 & 45.73 & 527.35 & -0.91 \\
\hline 431 & unfail & unfail & 31.47 & 142.99 & 454.35 & 3.02 & 22.50 & 170.80 & -1.23 \\
\hline 432 & unfail & unfail & 10.51 & 348.59 & 811.48 & 0.89 & 61.88 & 448.91 & -0.51 \\
\hline 433 & unfail & unfail & 17.58 & 67.33 & 605.13 & 0.07 & 26.04 & 133.66 & -0.98 \\
\hline 434 & unfail & unfail & 8.72 & 158.09 & 761.05 & 0.17 & 24.65 & 346.01 & -0.45 \\
\hline 435 & unfail & unfail & 2.37 & 115.98 & 575.44 & 0.20 & 271.93 & 6.92 & -2.07 \\
\hline 436 & unfail & unfail & 21.78 & 173.14 & 666.23 & 0.25 & 505.01 & 188.61 & 0.03 \\
\hline 437 & unfail & unfail & 43.93 & 298.69 & 588.05 & 3.97 & 115.13 & 271.63 & -7.93 \\
\hline 438 & unfail & unfail & 5.88 & 123.32 & 1032.67 & 0.29 & 73.79 & 1072.81 & -0.31 \\
\hline 439 & unfail & unfail & 29.81 & 131.94 & 570.73 & -0.35 & 140.43 & 104.88 & 2.16 \\
\hline 440 & unfail & unfail & 19.54 & 27.37 & 800.22 & -1.86 & 39.17 & 620.41 & 0.51 \\
\hline 441 & unfail & unfail & 1.63 & 230.54 & 443.81 & -0.11 & 522.78 & 430.90 & -0.10 \\
\hline 442 & unfail & unfail & 2.54 & 138.62 & 984.98 & 0.74 & 188.76 & 1217.65 & 1.22 \\
\hline 443 & unfail & unfail & 13.89 & 330.57 & 520.90 & 0.13 & 71.11 & 272.51 & 0.44 \\
\hline 444 & unfail & unfail & 9.63 & 319.11 & 848.47 & 0.05 & 108.49 & 321.94 & -0.18 \\
\hline 445 & unfail & unfail & 22.26 & 232.72 & 772.78 & 0.29 & 10.24 & 188.30 & 0.21 \\
\hline 446 & unfail & unfail & 16.85 & 299.64 & 759.35 & 0.43 & 46.85 & 524.51 & -0.10 \\
\hline 447 & unfail & unfail & 25.32 & 97.84 & 675.29 & 1.68 & 45.50 & 69.08 & -0.53 \\
\hline 448 & unfail & unfail & 22.25 & 246.68 & 604.24 & -1.55 & 413.50 & 138.99 & 1.33 \\
\hline 449 & unfail & unfail & 6.68 & 170.77 & 757.67 & 0.88 & 104.31 & 416.74 & -0.36 \\
\hline 450 & unfail & unfail & 33.70 & 226.48 & 565.05 & -0.11 & 34.93 & 53.36 & -0.81 \\
\hline 451 & unfail & unfail & 23.10 & 22.23 & 783.50 & 0.84 & 91.59 & 158.79 & -0.90 \\
\hline 452 & unfail & unfail & 20.63 & 140.38 & 762.27 & -0.24 & 520.56 & 1360.29 & 0.32 \\
\hline 453 & unfail & unfail & 21.54 & 183.08 & 724.58 & -0.50 & 47.23 & 254.96 & -0.17 \\
\hline 454 & unfail & unfail & 27.17 & 315.39 & 712.97 & 0.61 & 40.32 & 264.64 & -0.44 \\
\hline 455 & unfail & unfail & 30.94 & 133.78 & 619.82 & -1.77 & 119.56 & 22.84 & -2.10 \\
\hline 456 & unfail & unfail & 26.25 & 321.61 & 647.86 & 0.97 & 2.31 & 152.67 & 0.18 \\
\hline 457 & unfail & unfail & 20.23 & 333.10 & 689.13 & -1.89 & 44.23 & 650.13 & -0.22 \\
\hline 458 & unfail & unfail & 10.88 & 74.48 & 724.86 & 1.75 & 210.16 & 230.68 & -4.96 \\
\hline 459 & unfail & unfail & 31.18 & 76.60 & 717.42 & -1.15 & 32.12 & 201.23 & 1.03 \\
\hline 460 & unfail & unfail & 14.97 & 303.14 & 784.76 & 3.13 & 4.25 & 441.71 & -1.89 \\
\hline 461 & unfail & unfail & 22.29 & 113.31 & 712.67 & 0.32 & 98.36 & 2.36 & 6.30 \\
\hline 462 & unfail & unfail & 0.76 & 119.88 & 445.24 & 0.24 & 258.37 & 157.84 & 0.09 \\
\hline 463 & unfail & unfail & 22.16 & 37.06 & 773.38 & -0.50 & 190.60 & 732.20 & 1.02 \\
\hline 464 & unfail & unfail & 27.03 & 301.24 & 762.42 & 0.23 & 162.36 & 352.80 & -0.81 \\
\hline 465 & unfail & unfail & 29.21 & 33.96 & 620.39 & 0.12 & 93.35 & 124.84 & 0.23 \\
\hline 466 & unfail & unfail & 29.46 & 250.10 & 651.20 & 0.02 & 264.95 & 155.69 & 0.22 \\
\hline
\end{tabular}




\begin{tabular}{|c|c|c|c|c|c|c|c|c|c|}
\hline Value & Status & Type & $\begin{array}{l}\text { Slope } \\
\left({ }^{\circ}\right)\end{array}$ & $\begin{array}{l}\text { Aspect } \\
\left({ }^{\circ}\right)\end{array}$ & $\begin{array}{l}\text { Elevation } \\
(\mathrm{m})\end{array}$ & $\begin{array}{l}\text { Curvature } \\
\text { (radians per } \\
\text { meter) }\end{array}$ & $\begin{array}{l}\text { Dist. to } \\
\text { Roads (m) }\end{array}$ & $\begin{array}{l}\text { Dist. to } \\
\text { Streams } \\
(\mathrm{m})\end{array}$ & $\begin{array}{l}\text { Profile curvature } \\
\text { (radians per } \\
\text { meter) }\end{array}$ \\
\hline 467 & unfail & unfail & 11.30 & 290.30 & 847.65 & 3.76 & 4.06 & 557.94 & -2.04 \\
\hline 468 & unfail & unfail & 25.76 & 326.24 & 672.49 & -1.20 & 75.78 & 255.28 & -0.31 \\
\hline 469 & unfail & unfail & 28.96 & 335.53 & 738.11 & -1.48 & 57.59 & 248.16 & 2.46 \\
\hline 470 & unfail & unfail & 26.56 & 244.67 & 675.56 & -0.05 & 22.88 & 76.15 & -0.27 \\
\hline 471 & unfail & unfail & 11.35 & 106.07 & 641.67 & 0.10 & 23.40 & 244.25 & 0.48 \\
\hline 472 & unfail & unfail & 27.52 & 174.62 & 583.98 & 0.73 & 117.88 & 55.06 & 0.29 \\
\hline 473 & unfail & unfail & 4.20 & 160.57 & 488.18 & -0.51 & 156.39 & 10.67 & 2.80 \\
\hline 474 & unfail & unfail & 35.91 & 22.14 & 691.93 & 1.12 & 17.00 & 113.00 & 0.85 \\
\hline 475 & unfail & unfail & 28.11 & 199.15 & 476.63 & 1.48 & 22.57 & 43.54 & 0.56 \\
\hline 476 & unfail & unfail & 33.81 & 59.80 & 659.27 & 0.71 & 38.65 & 144.21 & 0.34 \\
\hline 477 & unfail & unfail & 7.17 & 152.49 & 796.81 & 0.65 & 84.67 & 254.10 & -1.39 \\
\hline 478 & unfail & unfail & 14.74 & 280.57 & 846.99 & 0.64 & 7.00 & 275.53 & 0.97 \\
\hline 479 & unfail & unfail & 22.83 & 51.41 & 620.04 & -2.08 & 171.57 & 25.09 & 2.90 \\
\hline 480 & unfail & unfail & 9.94 & 110.75 & 757.63 & -0.18 & 616.16 & 1419.42 & 0.43 \\
\hline 481 & unfail & unfail & 2.83 & 158.61 & 766.87 & 0.80 & 144.59 & 120.95 & -0.24 \\
\hline 482 & unfail & unfail & 6.26 & 140.99 & 793.86 & -0.23 & 52.80 & 154.14 & 0.60 \\
\hline 483 & unfail & unfail & 6.55 & 199.20 & 722.18 & -0.36 & 3.12 & 119.82 & 0.69 \\
\hline 484 & unfail & unfail & 35.46 & 196.34 & 500.68 & 0.13 & 142.57 & 27.90 & 2.07 \\
\hline 485 & unfail & unfail & 18.65 & 184.64 & 665.51 & -0.63 & 51.82 & 320.52 & 0.11 \\
\hline 486 & unfail & unfail & 33.38 & 279.08 & 535.59 & -1.79 & 131.66 & 137.78 & 0.13 \\
\hline 487 & unfail & unfail & 19.06 & 291.21 & 891.83 & 0.86 & 12.52 & 267.39 & 0.22 \\
\hline 488 & unfail & unfail & 24.84 & 291.64 & 753.45 & -0.79 & 126.21 & 506.28 & 3.16 \\
\hline 489 & unfail & unfail & 29.53 & 248.17 & 609.70 & -0.57 & 237.96 & 133.17 & 0.95 \\
\hline 490 & unfail & unfail & 13.60 & 70.54 & 525.35 & -0.23 & 47.78 & 78.66 & 3.12 \\
\hline 491 & unfail & unfail & 18.53 & 158.01 & 674.96 & -0.88 & 24.28 & 265.51 & 0.26 \\
\hline 492 & unfail & unfail & 30.71 & 190.44 & 1006.28 & 2.22 & 695.55 & 1793.78 & -3.44 \\
\hline 493 & unfail & unfail & 24.25 & 245.70 & 731.43 & 0.29 & 100.30 & 81.67 & -0.32 \\
\hline 494 & unfail & unfail & 6.34 & 237.43 & 997.54 & -1.71 & 48.20 & 823.93 & -0.27 \\
\hline 495 & unfail & unfail & 15.14 & 101.55 & 787.26 & 0.05 & 1361.78 & 2085.13 & 0.27 \\
\hline 496 & unfail & unfail & 17.77 & 317.72 & 909.74 & 1.62 & 7.94 & 912.40 & -1.69 \\
\hline 497 & unfail & unfail & 28.12 & 186.68 & 830.77 & -0.40 & 6.73 & 575.96 & 0.45 \\
\hline 498 & unfail & unfail & 13.92 & 262.84 & 676.57 & -0.19 & 103.28 & 87.11 & -0.35 \\
\hline 499 & unfail & unfail & 29.55 & 350.24 & 732.72 & -0.01 & 23.15 & 202.90 & 0.31 \\
\hline 500 & unfail & unfail & 19.62 & 314.23 & 801.09 & 0.47 & 327.69 & 778.87 & -0.11 \\
\hline 501 & unfail & unfail & 17.80 & 352.93 & 872.21 & 0.53 & 46.36 & 852.30 & -1.28 \\
\hline 502 & unfail & unfail & 7.56 & 183.29 & 713.38 & -0.52 & 17.77 & 21.62 & 3.93 \\
\hline 503 & unfail & unfail & 10.60 & 315.24 & 838.59 & -0.31 & 40.28 & 626.26 & 0.06 \\
\hline 504 & unfail & unfail & 18.86 & 264.83 & 814.62 & 1.22 & 23.31 & 11.65 & -5.02 \\
\hline 505 & unfail & unfail & 11.40 & 234.21 & 742.50 & -0.29 & 518.44 & 1471.18 & 0.72 \\
\hline
\end{tabular}




\begin{tabular}{|c|c|c|c|c|c|c|c|c|c|}
\hline Value & Status & Type & $\begin{array}{l}\text { Slope } \\
\left({ }^{\circ}\right)\end{array}$ & $\begin{array}{l}\text { Aspect } \\
\left({ }^{\circ}\right)\end{array}$ & $\begin{array}{l}\text { Elevation } \\
(\mathrm{m})\end{array}$ & $\begin{array}{l}\text { Curvature } \\
\text { (radians per } \\
\text { meter) }\end{array}$ & $\begin{array}{l}\text { Dist. to } \\
\text { Roads (m) }\end{array}$ & $\begin{array}{l}\text { Dist. to } \\
\text { Streams } \\
(\mathrm{m})\end{array}$ & $\begin{array}{l}\text { Profile curvature } \\
\text { (radians per } \\
\text { meter) }\end{array}$ \\
\hline 506 & unfail & unfail & 22.81 & 215.59 & 639.28 & -1.17 & 17.40 & 261.18 & 1.06 \\
\hline 507 & unfail & unfail & 27.24 & 231.77 & 622.46 & -3.73 & 357.81 & 28.99 & 13.19 \\
\hline 508 & unfail & unfail & 9.61 & 46.86 & 542.08 & -0.92 & 661.43 & 178.56 & -0.28 \\
\hline 509 & unfail & unfail & 15.65 & 338.65 & 583.99 & -1.16 & 56.63 & 190.47 & 1.68 \\
\hline 510 & unfail & unfail & 19.53 & 287.49 & 731.53 & -0.32 & 111.07 & 376.66 & -0.39 \\
\hline 511 & unfail & unfail & 24.90 & 126.84 & 650.08 & -0.06 & 332.32 & 511.44 & 0.73 \\
\hline 512 & unfail & unfail & 10.97 & 267.77 & 1034.00 & -0.50 & 302.98 & 870.35 & 0.36 \\
\hline 513 & unfail & unfail & 17.00 & 332.63 & 961.48 & -0.06 & 69.00 & 859.84 & 0.02 \\
\hline 514 & unfail & unfail & 13.87 & 57.41 & 602.38 & -1.37 & 1.48 & 22.92 & 11.64 \\
\hline 515 & unfail & unfail & 15.90 & 287.46 & 754.37 & 0.47 & 55.98 & 370.18 & -0.40 \\
\hline 516 & unfail & unfail & 7.38 & 279.72 & 776.47 & 0.95 & 34.77 & 419.57 & -0.54 \\
\hline 517 & unfail & unfail & 14.05 & 304.15 & 749.17 & -0.30 & 16.24 & 269.76 & 0.32 \\
\hline 518 & unfail & unfail & 16.16 & 289.49 & 887.67 & -0.17 & 27.27 & 387.24 & 0.52 \\
\hline 519 & unfail & unfail & 4.88 & 104.74 & 773.73 & 0.55 & 1181.03 & 1158.48 & -0.87 \\
\hline 520 & unfail & unfail & 1.33 & 126.85 & 449.03 & 0.28 & 1376.23 & 1286.52 & 0.50 \\
\hline 521 & unfail & unfail & 5.65 & 53.91 & 814.16 & -1.92 & 38.86 & 205.33 & 0.49 \\
\hline 522 & unfail & unfail & 31.44 & 94.67 & 697.02 & -1.30 & 187.39 & 264.69 & 3.58 \\
\hline 523 & unfail & unfail & 23.09 & 89.85 & 795.32 & 1.05 & 16.69 & 64.52 & -1.90 \\
\hline 524 & unfail & unfail & 12.49 & 200.25 & 769.54 & -0.20 & 103.79 & 721.95 & 0.28 \\
\hline 525 & unfail & unfail & 25.11 & 70.37 & 748.23 & 0.40 & 3.66 & 350.98 & 2.94 \\
\hline 526 & unfail & unfail & 23.99 & 297.88 & 734.24 & -0.87 & 24.41 & 331.35 & -1.82 \\
\hline 527 & unfail & unfail & 21.90 & 350.77 & 687.85 & -0.25 & 5.33 & 293.99 & 1.95 \\
\hline 528 & unfail & unfail & 25.81 & 73.51 & 702.95 & 0.05 & 295.91 & 236.96 & 0.63 \\
\hline 529 & unfail & unfail & 15.31 & 176.11 & 730.69 & -0.17 & 54.69 & 227.84 & 0.14 \\
\hline 530 & unfail & unfail & 7.54 & 169.41 & 837.84 & 0.03 & 1175.64 & 1586.73 & -0.16 \\
\hline 531 & unfail & unfail & 19.38 & 280.81 & 731.97 & -1.35 & 52.12 & 235.82 & 0.26 \\
\hline 532 & unfail & unfail & 5.01 & 198.55 & 605.54 & 0.78 & 51.08 & 14.87 & 0.05 \\
\hline 533 & unfail & unfail & 6.21 & 251.19 & 725.07 & -3.31 & 264.75 & 1518.11 & 3.44 \\
\hline 534 & unfail & unfail & 15.09 & 274.87 & 715.08 & -0.15 & 8.78 & 358.38 & -0.54 \\
\hline 535 & unfail & unfail & 21.40 & 107.22 & 771.49 & -0.47 & 22.28 & 372.41 & -1.70 \\
\hline 536 & unfail & unfail & 17.60 & 221.95 & 810.71 & 0.44 & 126.26 & 458.00 & 0.19 \\
\hline 537 & unfail & unfail & 40.80 & 50.77 & 609.43 & -0.53 & 284.92 & 300.82 & -0.25 \\
\hline 538 & unfail & unfail & 22.45 & 317.54 & 719.34 & -0.06 & 12.51 & 39.37 & -0.61 \\
\hline 539 & unfail & unfail & 1.76 & 131.84 & 773.48 & 0.98 & 142.85 & 349.58 & -0.82 \\
\hline 540 & unfail & unfail & 35.51 & 45.62 & 611.49 & -0.45 & 165.09 & 108.69 & 1.12 \\
\hline 541 & unfail & unfail & 3.75 & 294.93 & 835.98 & -0.18 & 109.68 & 948.76 & -0.22 \\
\hline 542 & unfail & unfail & 19.77 & 107.41 & 712.31 & 4.69 & 76.17 & 871.59 & -0.14 \\
\hline 543 & unfail & unfail & 22.94 & 8.19 & 735.35 & 0.22 & 54.53 & 210.03 & 0.47 \\
\hline 544 & unfail & unfail & 20.03 & 254.70 & 674.89 & -0.41 & 817.67 & 1113.10 & -0.46 \\
\hline
\end{tabular}




\begin{tabular}{|c|c|c|c|c|c|c|c|c|c|}
\hline Value & Status & Type & $\begin{array}{l}\text { Slope } \\
\left({ }^{\circ}\right)\end{array}$ & $\begin{array}{l}\text { Aspect } \\
\left(^{\circ}\right)\end{array}$ & $\begin{array}{l}\text { Elevation } \\
(\mathrm{m})\end{array}$ & $\begin{array}{l}\text { Curvature } \\
\text { (radians per } \\
\text { meter) }\end{array}$ & $\begin{array}{l}\text { Dist. to } \\
\text { Roads (m) }\end{array}$ & $\begin{array}{l}\text { Dist. to } \\
\text { Streams } \\
\text { (m) }\end{array}$ & $\begin{array}{l}\text { Profile curvature } \\
\text { (radians per } \\
\text { meter) }\end{array}$ \\
\hline 545 & unfail & unfail & 23.23 & 118.47 & 674.56 & 0.49 & 8.12 & 105.78 & 1.57 \\
\hline 546 & unfail & unfail & 12.54 & 282.99 & 760.47 & 1.03 & 132.74 & 377.68 & -0.23 \\
\hline 547 & unfail & unfail & 31.23 & 182.54 & 636.39 & 0.32 & 110.59 & 721.55 & -0.40 \\
\hline 548 & unfail & unfail & 25.15 & 77.93 & 800.63 & 0.67 & 504.63 & 646.81 & -0.16 \\
\hline 549 & unfail & unfail & 15.40 & 134.67 & 813.63 & 0.85 & 35.80 & 466.57 & -0.90 \\
\hline 550 & unfail & unfail & 21.58 & 299.82 & 715.53 & 0.69 & 50.58 & 181.91 & 0.32 \\
\hline 551 & unfail & unfail & 14.38 & 216.13 & 799.68 & 0.13 & 18.58 & 345.48 & -1.73 \\
\hline 552 & unfail & unfail & 32.59 & 137.03 & 634.82 & -0.08 & 52.45 & 87.71 & -5.79 \\
\hline 553 & unfail & unfail & 12.94 & 37.25 & 596.16 & 0.22 & 23.08 & 224.42 & -0.68 \\
\hline 554 & unfail & unfail & 24.84 & 271.94 & 693.83 & 1.09 & 14.42 & 148.38 & -0.56 \\
\hline 555 & unfail & unfail & 17.12 & 316.82 & 910.07 & 0.09 & 47.26 & 607.69 & -0.91 \\
\hline 556 & unfail & unfail & 5.38 & 269.36 & 560.87 & -0.51 & 117.38 & 3.00 & 2.45 \\
\hline 557 & unfail & unfail & 32.82 & 319.66 & 642.13 & 0.31 & 29.70 & 240.39 & 0.89 \\
\hline 558 & unfail & unfail & 20.68 & 190.22 & 653.62 & -1.23 & 513.85 & 919.49 & -0.72 \\
\hline 559 & unfail & unfail & 12.42 & 182.55 & 803.98 & -3.45 & 64.00 & 629.95 & 4.24 \\
\hline 560 & unfail & unfail & 31.42 & 76.38 & 707.42 & -0.25 & 176.97 & 230.98 & 0.27 \\
\hline 561 & unfail & unfail & 28.67 & 160.63 & 555.31 & 0.73 & 191.26 & 17.37 & -0.84 \\
\hline 562 & unfail & unfail & 11.95 & 205.56 & 699.82 & -0.54 & 203.12 & 145.23 & 0.31 \\
\hline 563 & unfail & unfail & 18.54 & 207.46 & 735.21 & 0.10 & 23.14 & 857.34 & 0.01 \\
\hline 564 & unfail & unfail & 14.96 & 328.37 & 607.56 & -0.84 & 44.17 & 372.66 & 0.62 \\
\hline 565 & unfail & unfail & 8.84 & 256.98 & 754.86 & -0.05 & 47.77 & 124.36 & 0.21 \\
\hline 566 & unfail & unfail & 34.63 & 45.72 & 604.83 & -1.54 & 18.01 & 87.65 & 2.52 \\
\hline 567 & unfail & unfail & 24.86 & 64.34 & 599.67 & 1.22 & 2.05 & 46.68 & 2.05 \\
\hline 568 & unfail & unfail & 39.43 & 284.21 & 658.38 & -0.46 & 27.23 & 16.77 & -10.02 \\
\hline 569 & unfail & unfail & 4.74 & 173.48 & 792.33 & 0.67 & 111.36 & 256.92 & -0.62 \\
\hline 570 & unfail & unfail & 25.29 & 63.53 & 730.89 & -0.10 & 285.93 & 1296.41 & -0.14 \\
\hline 571 & unfail & unfail & 16.66 & 324.19 & 846.30 & -0.46 & 391.77 & 1290.63 & 0.14 \\
\hline 572 & unfail & unfail & 9.03 & 205.92 & 560.80 & -1.00 & 51.76 & 44.66 & 4.93 \\
\hline 573 & unfail & unfail & 25.55 & 345.49 & 675.92 & 0.81 & 165.26 & 111.36 & -0.24 \\
\hline 574 & unfail & unfail & 17.21 & 310.21 & 917.55 & -0.02 & 5.60 & 823.93 & -0.09 \\
\hline 575 & unfail & unfail & 17.74 & 321.45 & 927.45 & -1.30 & 2.01 & 725.51 & 1.77 \\
\hline 576 & unfail & unfail & 32.37 & 135.95 & 632.31 & 4.14 & 210.04 & 235.25 & 0.38 \\
\hline 577 & unfail & unfail & 30.19 & 87.91 & 622.69 & 0.11 & 381.44 & 116.92 & 0.22 \\
\hline 578 & unfail & unfail & 6.71 & 188.83 & 596.01 & -1.91 & 158.06 & 9.60 & 5.69 \\
\hline 579 & unfail & unfail & 20.21 & 277.56 & 652.57 & -0.34 & 13.88 & 352.78 & -0.04 \\
\hline 580 & unfail & unfail & 3.95 & 125.57 & 492.96 & 0.60 & 109.44 & 35.32 & -0.95 \\
\hline 581 & unfail & unfail & 9.02 & 54.48 & 727.35 & 3.09 & 132.41 & 1195.87 & -0.48 \\
\hline 582 & unfail & unfail & 23.40 & 223.12 & 703.43 & -0.43 & 123.85 & 435.91 & 0.64 \\
\hline 583 & unfail & unfail & 10.35 & 158.28 & 737.35 & 1.28 & 27.87 & 152.22 & -0.41 \\
\hline
\end{tabular}




\begin{tabular}{|c|c|c|c|c|c|c|c|c|c|}
\hline Value & Status & Type & $\begin{array}{l}\text { Slope } \\
\left({ }^{\circ}\right)\end{array}$ & $\begin{array}{l}\text { Aspect } \\
\left({ }^{\circ}\right)\end{array}$ & $\begin{array}{l}\text { Elevation } \\
(\mathrm{m})\end{array}$ & $\begin{array}{l}\text { Curvature } \\
\text { (radians per } \\
\text { meter) }\end{array}$ & $\begin{array}{l}\text { Dist. to } \\
\text { Roads (m) }\end{array}$ & $\begin{array}{l}\begin{array}{l}\text { Dist. to } \\
\text { Streams } \\
(\mathrm{m})\end{array} \\
\end{array}$ & $\begin{array}{l}\text { Profile curvature } \\
\text { (radians per } \\
\text { meter) }\end{array}$ \\
\hline 584 & unfail & unfail & 16.32 & 288.37 & 726.17 & 0.66 & 20.11 & 14.84 & -0.83 \\
\hline 585 & unfail & unfail & 5.28 & 174.15 & 814.69 & 1.23 & 64.92 & 663.78 & -1.14 \\
\hline 586 & unfail & unfail & 25.17 & 116.45 & 588.76 & -0.34 & 216.60 & 33.04 & 0.43 \\
\hline 587 & unfail & unfail & 38.67 & 47.32 & 497.75 & -1.36 & 39.11 & 5.33 & 5.11 \\
\hline 588 & unfail & unfail & 24.57 & 152.89 & 740.48 & 0.51 & 638.96 & 304.31 & -0.93 \\
\hline 589 & unfail & unfail & 10.84 & 356.76 & 840.22 & 0.09 & 142.61 & 434.73 & -0.33 \\
\hline 590 & unfail & unfail & 34.56 & 286.01 & 575.77 & -0.79 & 164.11 & 24.39 & 1.77 \\
\hline 591 & unfail & unfail & 8.84 & 212.68 & 772.28 & 0.55 & 59.86 & 223.10 & 0.40 \\
\hline 592 & unfail & unfail & 9.59 & 268.32 & 746.72 & 0.25 & 78.86 & 203.56 & -0.54 \\
\hline 593 & unfail & unfail & 21.42 & 295.17 & 695.60 & -0.40 & 22.89 & 444.76 & -0.10 \\
\hline 594 & unfail & unfail & 18.74 & 165.91 & 737.91 & -0.15 & 57.22 & 467.00 & -0.03 \\
\hline 595 & unfail & unfail & 23.91 & 41.71 & 598.45 & 1.35 & 30.08 & 111.97 & -2.29 \\
\hline 596 & unfail & unfail & 20.03 & 187.24 & 687.06 & -0.27 & 487.51 & 303.06 & -0.06 \\
\hline 597 & unfail & unfail & 16.74 & 213.49 & 622.50 & -0.31 & 11.55 & 21.06 & -0.36 \\
\hline 598 & unfail & unfail & 26.33 & 33.47 & 701.14 & -1.47 & 10.78 & 218.12 & 1.42 \\
\hline 599 & unfail & unfail & 13.60 & 253.34 & 720.45 & -4.19 & 120.12 & 41.76 & 3.85 \\
\hline 600 & unfail & unfail & 14.67 & 121.62 & 765.90 & 0.61 & 644.85 & 1539.21 & -0.41 \\
\hline 601 & unfail & unfail & 12.29 & 103.83 & 741.95 & -0.05 & 2.92 & 129.53 & -2.38 \\
\hline 602 & unfail & unfail & 28.72 & 47.83 & 540.97 & 0.68 & 224.77 & 37.72 & 10.14 \\
\hline 603 & unfail & unfail & 25.74 & 90.65 & 449.15 & 3.10 & 773.89 & 656.19 & -15.10 \\
\hline
\end{tabular}


Appendix B: Two sample student's t-tests for each variable and type of slope movement. Results show significant difference at the $95 \%$ confidence limit. 


\begin{tabular}{|l|l|l|l|l|l|l|}
\hline Slope Angle & $\begin{array}{l}\text { Active } \\
\text { Slopes }\end{array}$ & Planar Slides & $\begin{array}{l}\text { Rotational } \\
\text { Slumps }\end{array}$ & Debris Fans & Debris Flows & Debris Slides \\
\hline Active Slopes & EQUAL & & & & & \\
\hline Planar Slides & Different & EQUAL & & & & \\
\hline $\begin{array}{l}\text { Rotational } \\
\text { Slumps }\end{array}$ & Different & Similar & EQUAL & & & \\
\hline Debris Fans & Different & Different & Different & EQUAL & & \\
\hline Debris Flows & Different & Different & Different & Different & EQUAL & \\
\hline Debris Slides & Similar & Different & Different & Different & Similar & EQUAL \\
\hline Unfailed & Different & Similar & Similar & Different & Different & Different \\
\hline
\end{tabular}

\begin{tabular}{|l|l|l|l|l|l|l|}
\hline Elevation & $\begin{array}{l}\text { Active } \\
\text { Slopes }\end{array}$ & Planar Slides & $\begin{array}{l}\text { Rotational } \\
\text { Slumps }\end{array}$ & Debris Fans & Debris Flows & Debris Slides \\
\hline Active Slopes & EQUAL & & & & & \\
\hline Planar Slides & Different & EQUAL & & & & \\
\hline $\begin{array}{l}\text { Rotational } \\
\text { Slumps }\end{array}$ & Different & Similar & EQUAL & & & \\
\hline Debris Fans & Different & Similar & Similar & EQUAL & & \\
\hline Debris Flows & Different & Different & Different & Different & EQUAL & \\
\hline Debris Slides & Different & Different & Different & Similar & Different & EQUAL \\
\hline Unfailed & Different & Different & Similar & Different & Similar & Different \\
\hline
\end{tabular}




\begin{tabular}{|l|l|l|l|l|l|l|}
\hline Plan Curvature & $\begin{array}{l}\text { Active } \\
\text { Slopes }\end{array}$ & Planar Slides & $\begin{array}{l}\text { Rotational } \\
\text { Slumps }\end{array}$ & Debris Fans & Debris Flows & Debris Slides \\
\hline Active Slopes & EQUAL & & & & & \\
\hline Planar Slides & Similar & EQUAL & & & & \\
\hline $\begin{array}{l}\text { Rotational } \\
\text { Slumps }\end{array}$ & Similar & Similar & EQUAL & & & \\
\hline Debris Fans & Different & Different & Different & EQUAL & & \\
\hline Debris Flows & Similar & Similar & Different & Similar & EQUAL & \\
\hline Debris Slides & Similar & Similar & Similar & Different & Similar & EQUAL \\
\hline Unfailed & Different & Different & Different & Different & Different & Similar \\
\hline
\end{tabular}

\begin{tabular}{|l|l|l|l|l|l|l|}
\hline $\begin{array}{l}\text { Profile } \\
\text { Curvature }\end{array}$ & $\begin{array}{l}\text { Active } \\
\text { Slopes }\end{array}$ & Planar Slides & $\begin{array}{l}\text { Rotational } \\
\text { Slumps }\end{array}$ & Debris Fans & Debris Flows & Debris Slides \\
\hline Active Slopes & EQUAL & & & & & \\
\hline Planar Slides & Different & EQUAL & & & & \\
\hline $\begin{array}{l}\text { Rotational } \\
\text { Slumps }\end{array}$ & Different & Different & EQUAL & & & \\
\hline Debris Fans & Similar & Similar & Similar & EQUAL & & \\
\hline Debris Flows & Similar & Different & Similar & Similar & EQUAL & \\
\hline Debris Slides & Similar & Different & Different & Similar & Similar & EQUAL \\
\hline Unfailed & Different & Different & Similar & Similar & Similar & Similar \\
\hline
\end{tabular}




\begin{tabular}{|l|l|l|l|l|l|l|}
\hline $\begin{array}{l}\text { Distance from } \\
\text { Roads }\end{array}$ & $\begin{array}{l}\text { Active } \\
\text { Slopes }\end{array}$ & Planar Slides & $\begin{array}{l}\text { Rotational } \\
\text { Slumps }\end{array}$ & Debris Fans & Debris Flows & Debris Slides \\
\hline Active Slopes & EQUAL & & & & & \\
\hline Planar Slides & Similar & EQUAL & & & & \\
\hline $\begin{array}{l}\text { Rotational } \\
\text { Slumps }\end{array}$ & Different & Similar & EQUAL & & & \\
\hline Debris Fans & Different & Different & Similar & EQUAL & & \\
\hline Debris Flows & Different & Similar & Similar & Similar & EQUAL & \\
\hline Debris Slides & Similar & Similar & Different & Different & Different & EQUAL \\
\hline Unfailed & Different & Similar & Similar & Different & Similar & Different \\
\hline
\end{tabular}

\begin{tabular}{|l|l|l|l|l|l|l|}
\hline $\begin{array}{l}\text { Distance from } \\
\text { Streams }\end{array}$ & $\begin{array}{l}\text { Active } \\
\text { Slopes }\end{array}$ & Planar Slides & $\begin{array}{l}\text { Rotational } \\
\text { Slumps }\end{array}$ & Debris Fans & Debris Flows & Debris Slides \\
\hline Active Slopes & EQUAL & & & & & \\
\hline Planar Slides & Different & EQUAL & & & & \\
\hline $\begin{array}{l}\text { Rotational } \\
\text { Slumps }\end{array}$ & Different & Similar & EQUAL & & & \\
\hline Debris Fans & Different & Similar & Similar & EQUAL & & \\
\hline Debris Flows & Different & Different & Different & Different & EQUAL & \\
\hline Debris Slides & Different & Similar & Similar & Similar & Different & EQUAL \\
\hline Unfailed & Different & Similar & Similar & Similar & Different & Similar \\
\hline
\end{tabular}


Appendix C: Mean, standard deviation, and variance for each of seven landscape variables for the different types of slope movements mapped within Horseshoe Run watershed. 


\begin{tabular}{|l|r|r|r|}
\hline Variables for Active Slopes & \multicolumn{1}{|c|}{ Mean } & Standard Deviation & Variance \\
\hline Slope Angle $\left(^{\circ}\right)$ & 35.95 & 9.59 & 91.88 \\
\hline Elevation $(\mathrm{m})$ & 563.75 & 47.09 & 2217.26 \\
\hline Plan Curvature & -1.04 & 2.69 & 7.22 \\
\hline Profile Curvature & -1.70 & 4.49 & 20.14 \\
\hline Distance to Roads $(\mathrm{m})$ & 219.22 & 149.22 & 22265.65 \\
\hline Distance to Streams $(\mathrm{m})$ & 61.30 & 26.58 & 706.72 \\
\hline
\end{tabular}

\begin{tabular}{|l|r|r|r|}
\hline Variables for Debris Fans & \multicolumn{1}{|c|}{ Mean } & Standard Deviation & Variance \\
\hline Slope Angle $\left(^{\circ}\right)$ & 26.12 & 5.48 & 30.01 \\
\hline Elevation $(\mathrm{m})$ & 662.44 & 45.47 & 2067.72 \\
\hline Plan Curvature & -3.25 & 4.23 & 17.93 \\
\hline Profile Curvature & 0.49 & 2.76 & 7.64 \\
\hline Distance to Roads $(\mathrm{m})$ & 90.68 & 147.08 & 21633.41 \\
\hline Distance to Streams $(\mathrm{m})$ & 230.51 & 107.77 & 11613.54 \\
\hline
\end{tabular}

\begin{tabular}{|l|r|r|r|}
\hline Variables for Debris Flows & \multicolumn{1}{|c|}{ Mean } & Standard Deviation & Variance \\
\hline Slope Angle $\left(^{\circ}\right)$ & 30.30 & 3.14 & 9.88 \\
\hline Elevation $(\mathrm{m})$ & 717.16 & 50.12 & 2511.85 \\
\hline Plan Curvature & -1.52 & 2.02 & 4.07 \\
\hline Profile Curvature & 0.07 & 1.19 & 1.41 \\
\hline Distance to Roads $(\mathrm{m})$ & 115.78 & 112.01 & 12546.86 \\
\hline Distance to Streams $(\mathrm{m})$ & 440.88 & 167.75 & 28140.04 \\
\hline
\end{tabular}

\begin{tabular}{|l|r|r|r|}
\hline Variables for Rotational Slumps & \multicolumn{1}{|c|}{ Mean } & Standard Deviation & Variance \\
\hline Slope Angle $\left(^{\circ}\right)$ & 21.03 & 9.00 & 80.92 \\
\hline Elevation $(\mathrm{m})$ & 680.53 & 67.97 & 4619.57 \\
\hline Plan Curvature & -0.40 & 1.33 & 1.77 \\
\hline Profile Curvature & 0.67 & 1.52 & 2.32 \\
\hline Distance to Roads $(\mathrm{m})$ & 118.06 & 121.93 & 14867.36 \\
\hline Distance to Streams $(\mathrm{m})$ & 234.95 & 99.16 & 9833.14 \\
\hline
\end{tabular}

\begin{tabular}{|l|r|r|r|}
\hline Variables for Debris Slides & \multicolumn{1}{|c|}{ Mean } & Standard Deviation & Variance \\
\hline Slope Angle $\left(^{\circ}\right)$ & 32.28 & 4.73 & 22.34 \\
\hline Elevation $(\mathrm{m})$ & 625.49 & 71.31 & 5084.86 \\
\hline Plan Curvature & 0.11 & 2.66 & 7.07 \\
\hline Profile Curvature & -0.61 & 2.18 & 4.75 \\
\hline Distance to Roads $(\mathrm{m})$ & 217.79 & 183.92 & 33824.78 \\
\hline Distance to Streams $(\mathrm{m})$ & 220.73 & 86.82 & 7537.62 \\
\hline
\end{tabular}




\begin{tabular}{|l|r|r|r|}
\hline Variables for Planar Slides & Mean & Standard Deviation & Variance \\
\hline Slope Angle $\left({ }^{\circ}\right)$ & 21.77 & 9.18 & 84.19 \\
\hline Elevation $(\mathrm{m})$ & 670.39 & 69.49 & 4829.41 \\
\hline Plan Curvature & -0.94 & 1.76 & 3.08 \\
\hline Profile Curvature & 1.86 & 2.74 & 7.48 \\
\hline Distance to Roads $(\mathrm{m})$ & 139.69 & 136.44 & 18615.72 \\
\hline Distance to Streams $(\mathrm{m})$ & 210.78 & 99.41 & 9882.51 \\
\hline
\end{tabular}

\begin{tabular}{|l|r|r|r|}
\hline Variables for Unfailed Slopes & \multicolumn{1}{|c|}{ Mean } & Standard Deviation & Variance \\
\hline Slope Angle $\left(^{\circ}\right)$ & 19.25 & 9.67 & 93.49 \\
\hline Elevation $(\mathrm{m})$ & 702.73 & 115.32 & 13297.90 \\
\hline Plan Curvature & 0.10 & 1.29 & 1.66 \\
\hline Profile Curvature & 0.17 & 2.50 & 6.26 \\
\hline Distance to Roads $(\mathrm{m})$ & 142.24 & 202.20 & 40885.80 \\
\hline Distance to Streams $(\mathrm{m})$ & 347.57 & 362.12 & 131156.00 \\
\hline
\end{tabular}


Appendix D: Aspect data for each type of slope movement 


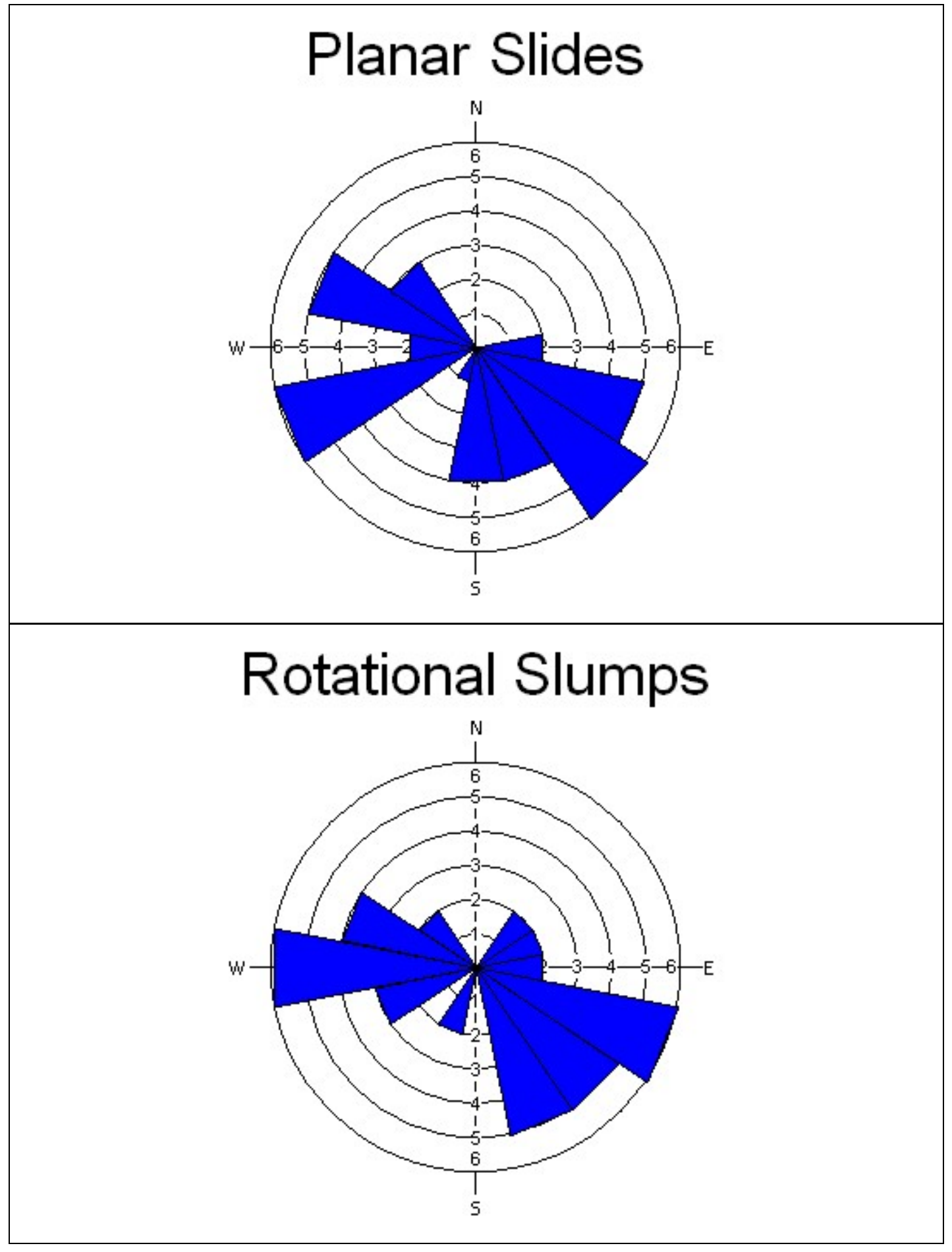




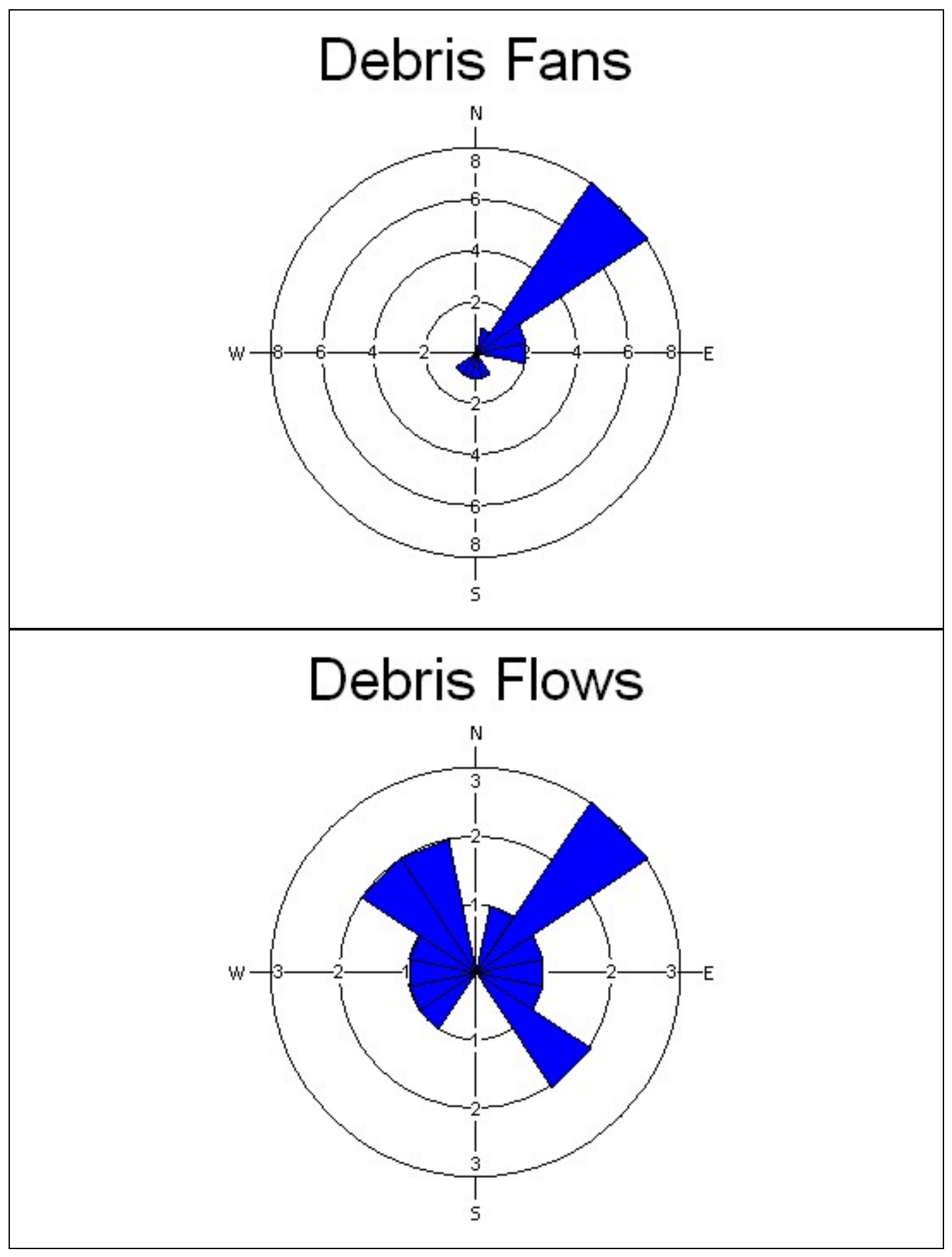




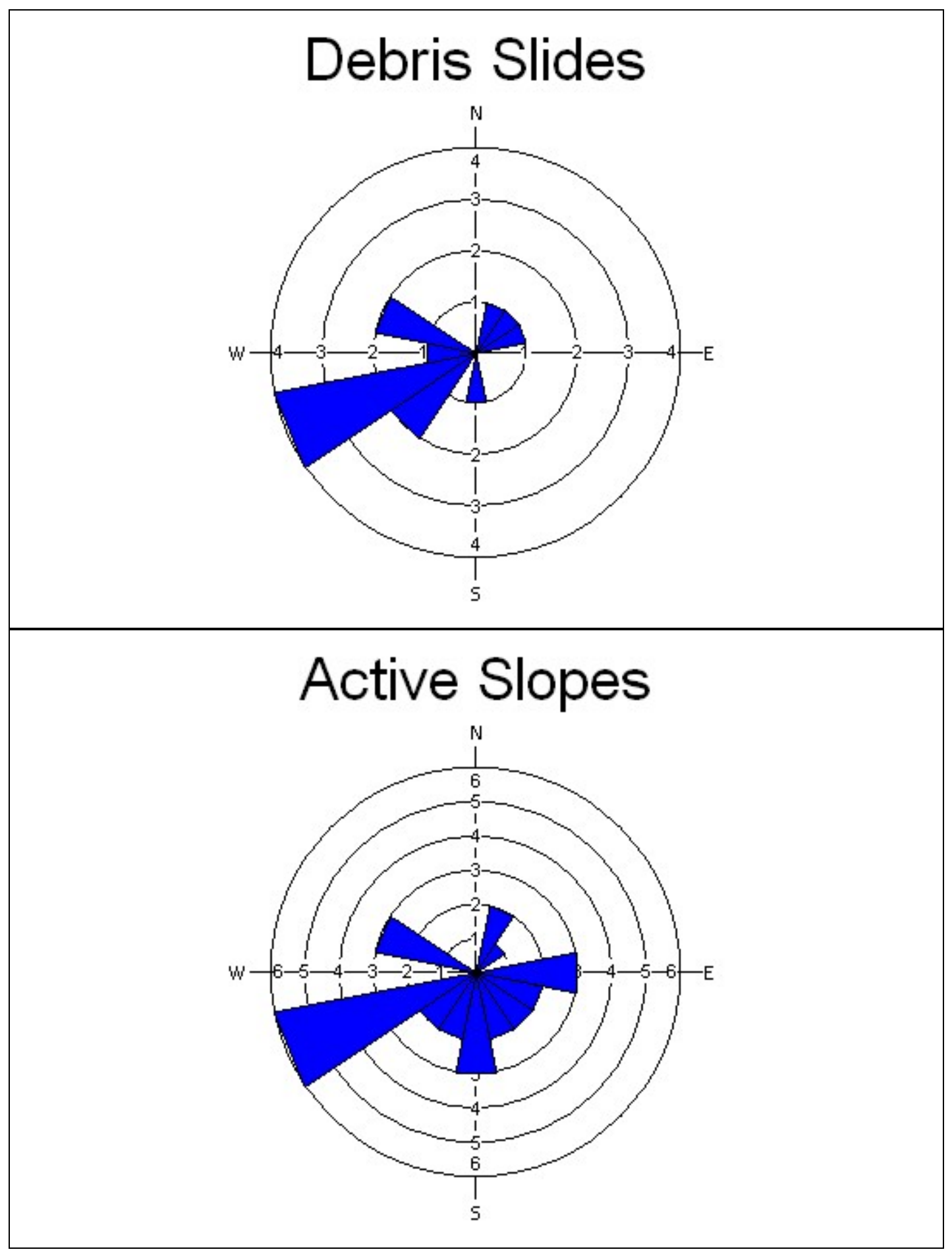




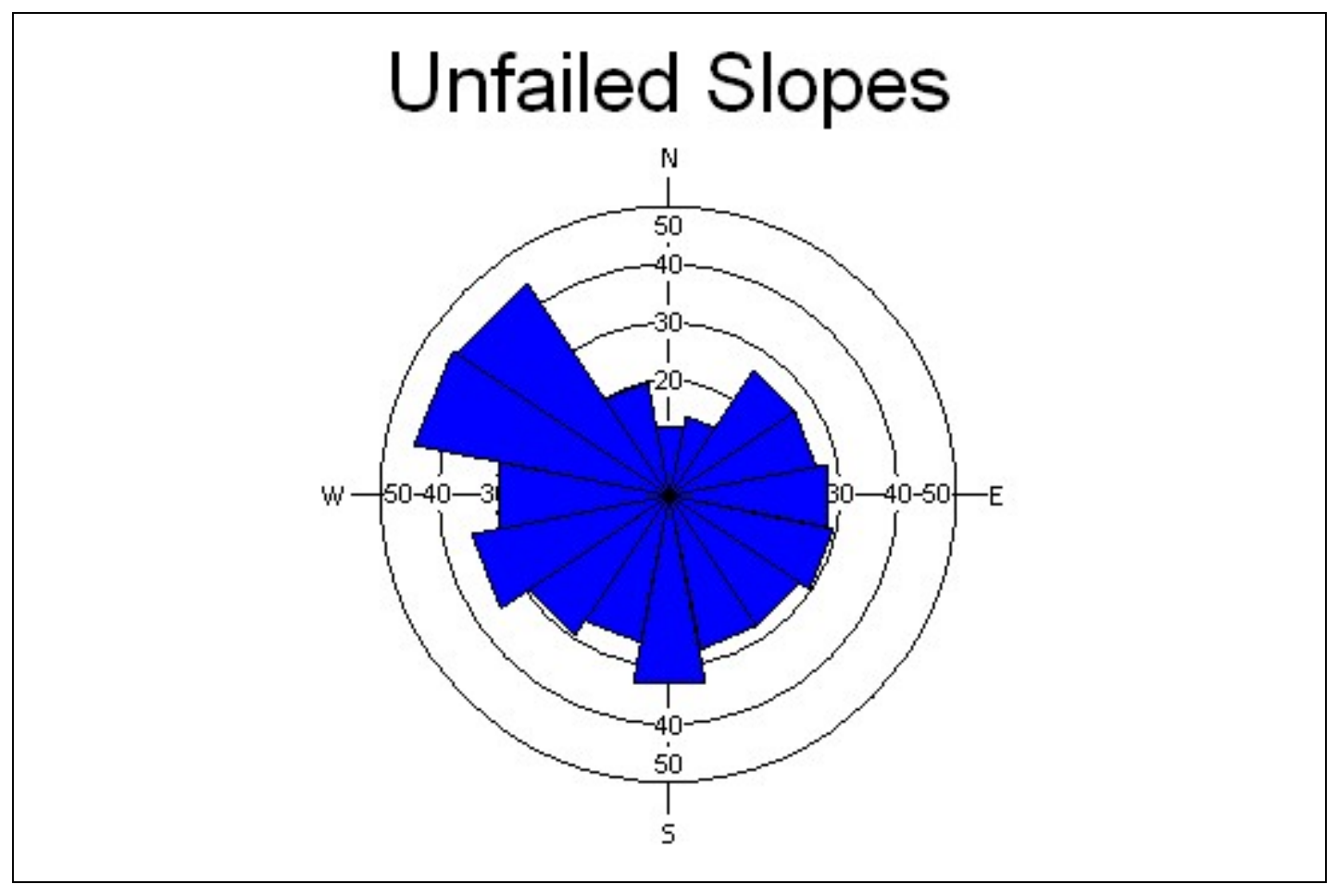


Appendix E: Aspect data for unfailed slopes categorized by slope angle 


\section{Unfailed Slopes (0-12 degrees)}

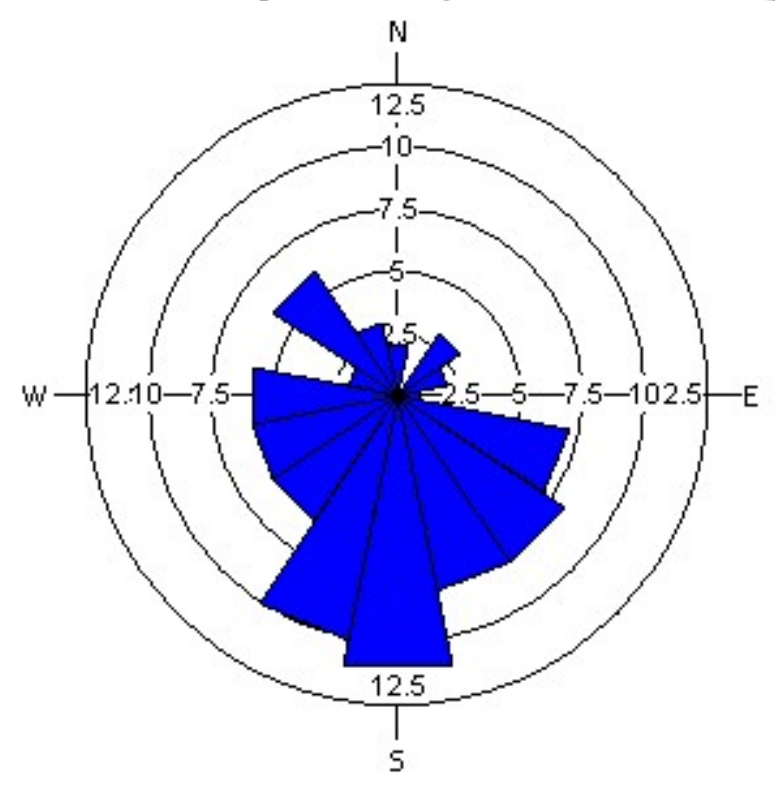

\section{Unfailed Slopes (12-20 degrees)}

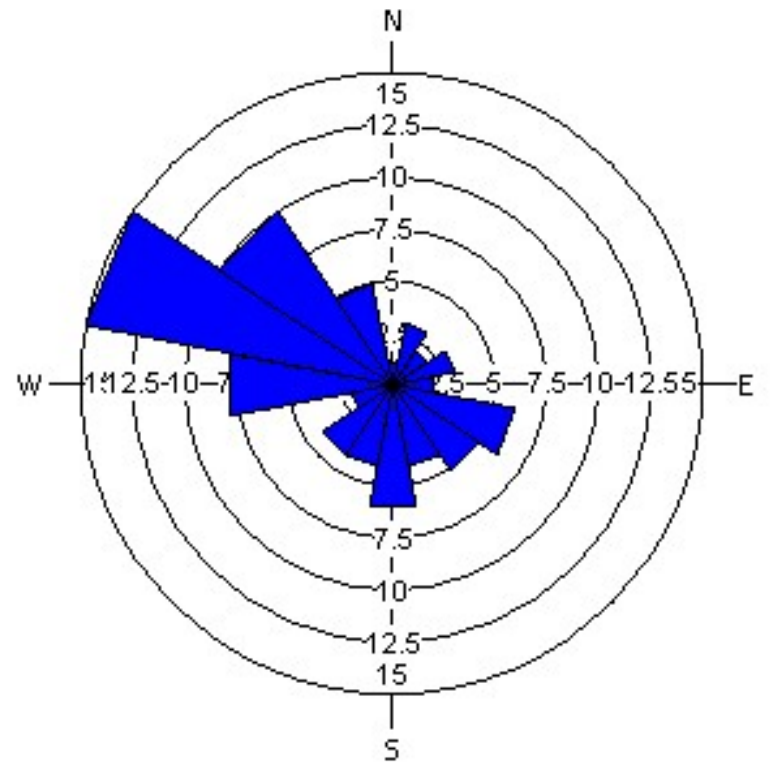




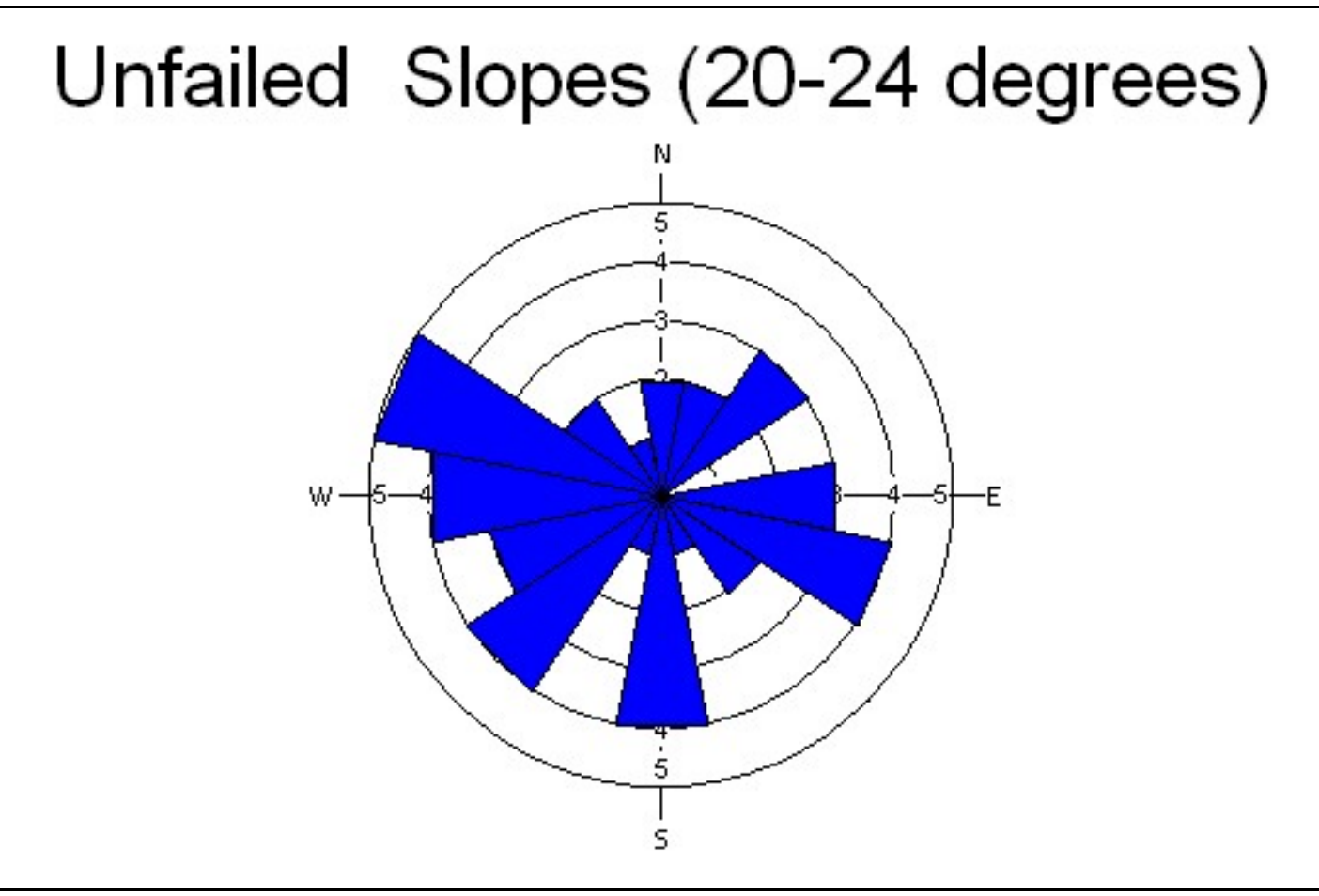

\section{Unfailed Slopes (24-28 degrees)}

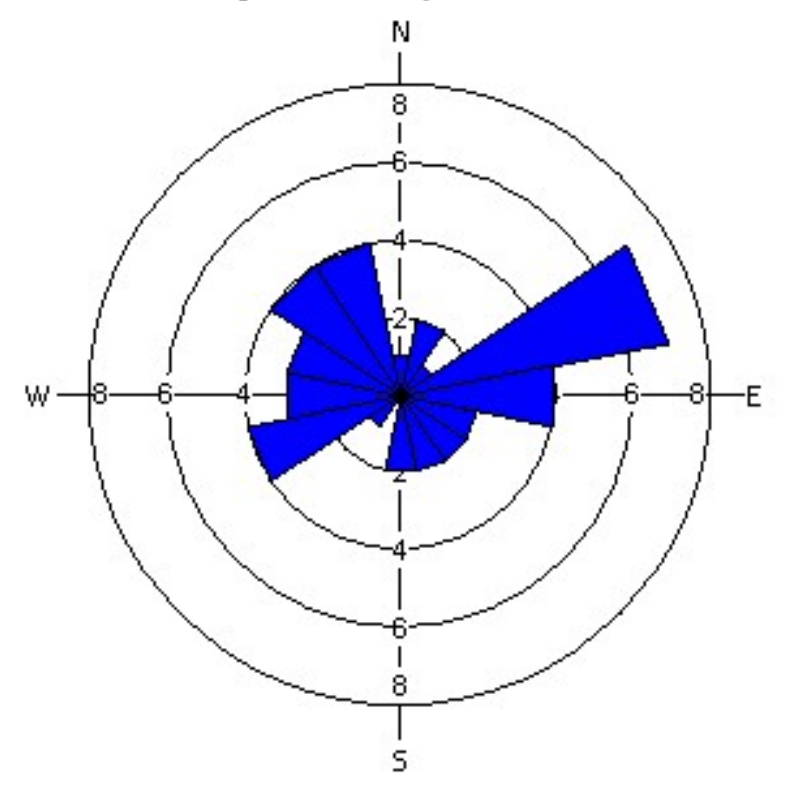




\section{Unfailed Slopes (28-32 degrees)}

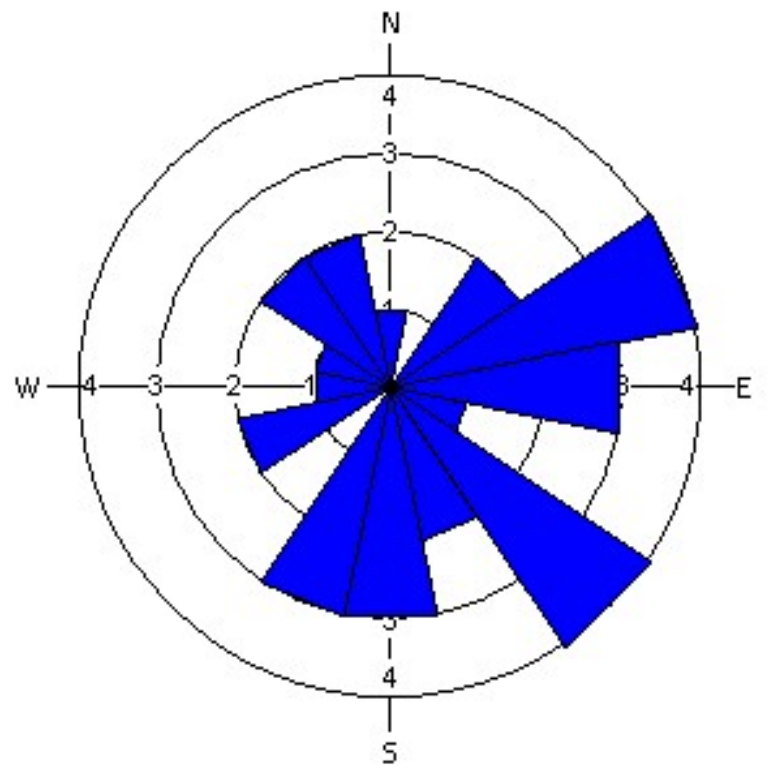

\section{Unfailed Slopes (32+ degrees)}

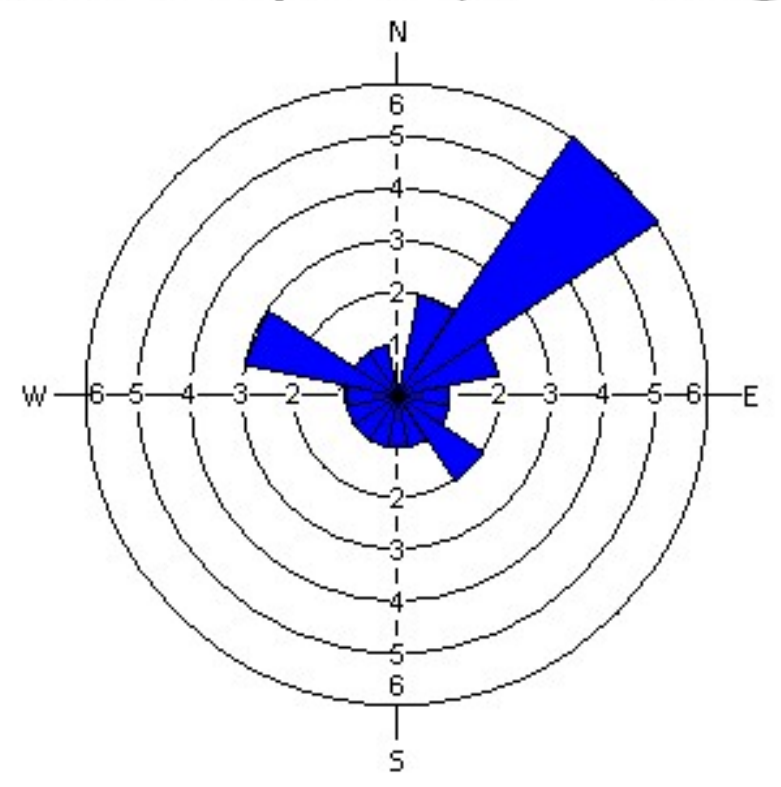


Appendix F: Primer on LiDAR data acquisition 
LiDAR (LIght Detection And Ranging) is a remote sensing technique similar to radar only instead of using radio waves, LiDAR involves the use of pulses of light (Lillesand, Kiefer, and Chipman, 2004). The pulses of light that are directed towards the Earth's surface are reflected off various features on the ground, either vegetation or ground surface, and the time required to return back to the sensor can be used to calculate elevation data (Lillesand, Kiefer, and Chipman, 2004). LiDAR data acquisition is performed using a photogrammetric aircraft with a high-resolution airborne GPS, an inertial measuring unit (IMU), a rapidly pulsing laser, a highly accurate clock, and substantial and robust computer capabilities (Lillesand, Kiefer, and Chipman, 2004). The GPS unit records the $x, y, z$, data for the sensor location and the IMU is required to measure the angular orientation of the sensor with respect to the ground. In most modern LiDAR sensors, 20,000 to 50,000 pulses of light can be emitted per second, or 20 to 50 kHz (Lillesand, Kiefer, and Chipman, 2004).

The accuracy of the LiDAR data and the associated cost of acquisition are a function of the operational parameters of the instrument and flight plan (Lovell et al., 2005). The main parameters that affect the LiDAR survey are aircraft height, flight speed, half scan angle, pulse frequency, and scan frequency (Lovell et al., 2005) (Figure 1). The zig-zag ground pattern of most LiDAR sensors is produced by a scanning mirror within the sensor, and half of the zig-zag pattern is considered the scan half angle. One method to increase the accuracy of the LiDAR data is to increase the density of the ground points, or footprint. This can be accomplished by decreasing the aircraft height, slowing the flight speed, or reducing the scan half angle (Hodgson and Bresnahan, 2004). An 


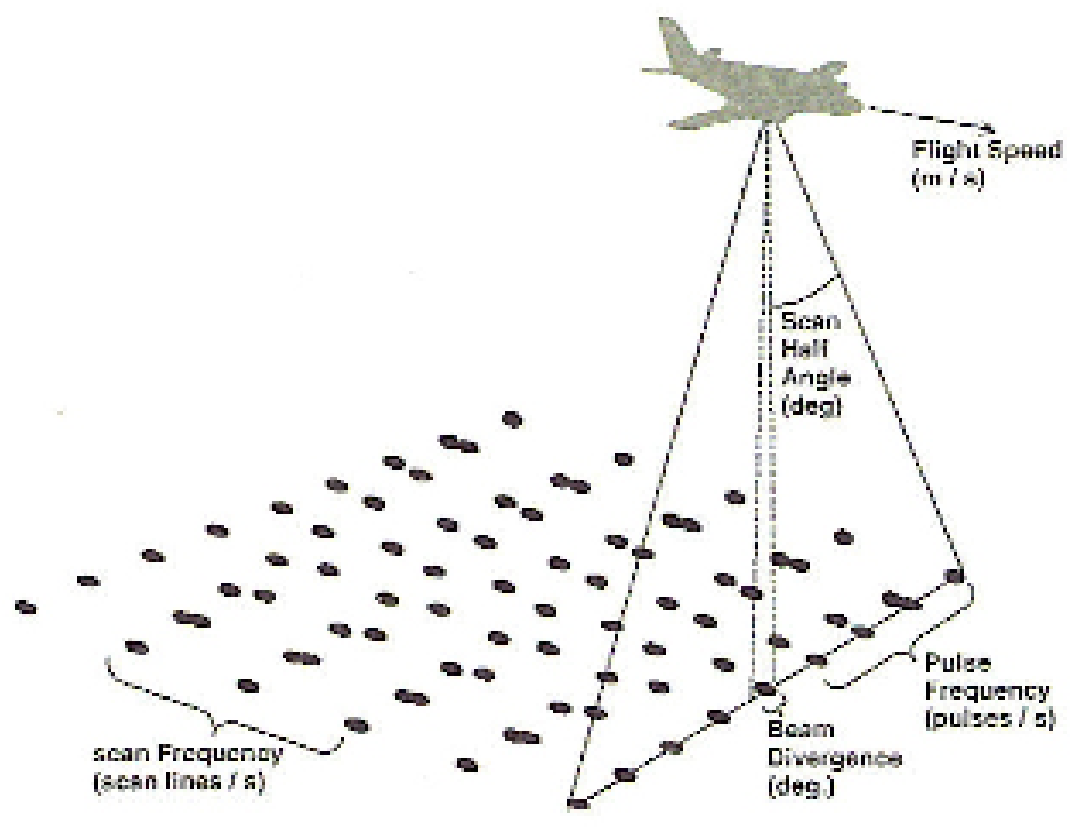

Figure 1: Diagram showing a generalized flight path for LiDAR data acquisition. Diagram taken from Lovell et al., 2005. 
additional parameter that can also have an affect on the accuracy of the LiDAR data is the scanning angle of the sensor, which is measured as the angle between a vertical line from the aircraft and the angle at which the light is being emitted (Holmgren, Nilsson, and Olsson, 2003) (Figure 2).

For most ground surface digital elevation models (DEM), LiDAR data acquisition is performed using a small scanning angle to ensure minimal interference with vegetation, and $30 \%$ to $50 \%$ of swath overlap to minimize gaps in the reflected LiDAR data (Lillesand, Kiefer, and Chipman, 2004). In addition to a small scanning angle, LiDAR acquisition is often performed during leaf-off and at low flight elevations in order to achieve small laser footprints under minimum interference conditions (Hodgson and Bresnahan, 2004).

A common wavelength of light used in LiDAR acquisition is $1064 \mathrm{~nm}$, which is in the near infrared spectrum (Holgren, Nilsson, and Olsson, 2003; Goodwin et al., 2006). A benefit of LiDAR is the number of reflections, or returns, that recorded by the sensor. As the thousand of light pulses are emitted from the laser, some of the light waves will reflect off the canopy leaves or braches of trees while others will penetrate through the leaf cover and reflect off understory vegetation and the ground surface. The multiple reflections can then be interpreted and correlated and multiple elevation surfaces can be derived (Lillesand, Kiefer, and Chipman, 2004) (Figure 3). Additionally, the magnitude of the reflected pulse can be recorded and is referred to as intensity (Hodgson and Bresnahan, 2004). These intensities can also be used to filter-out the less intense vegetation returns and provide the last returns which are reflected from the ground surface and are higher in magnitude (Hodgson and Bresnahan, 2004). 


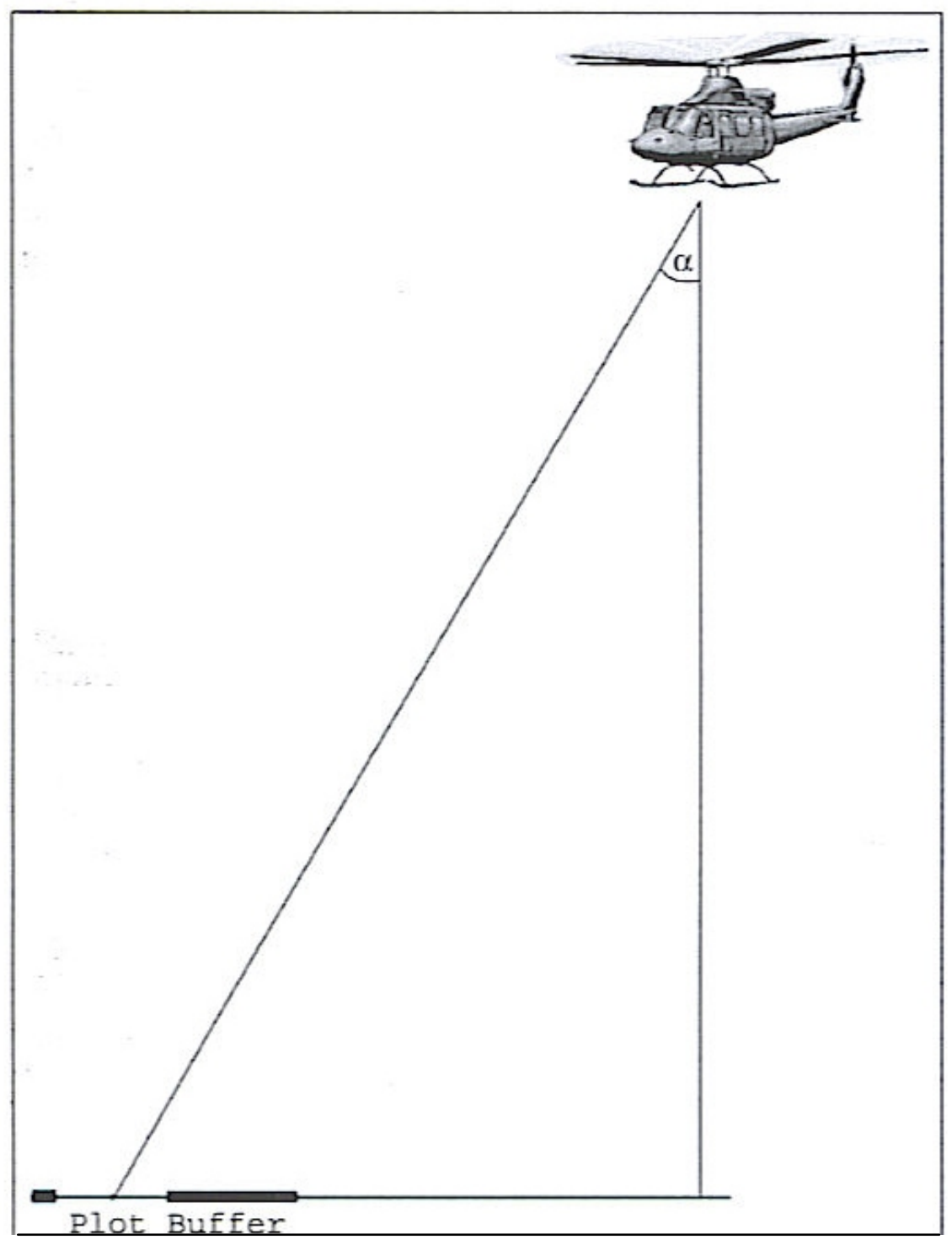

Figure 2: Diagram showing the scanning angle used during LiDAR data acquisition. Diagram taken from Holmgren, Nilsson, and Olsson, 2003. 

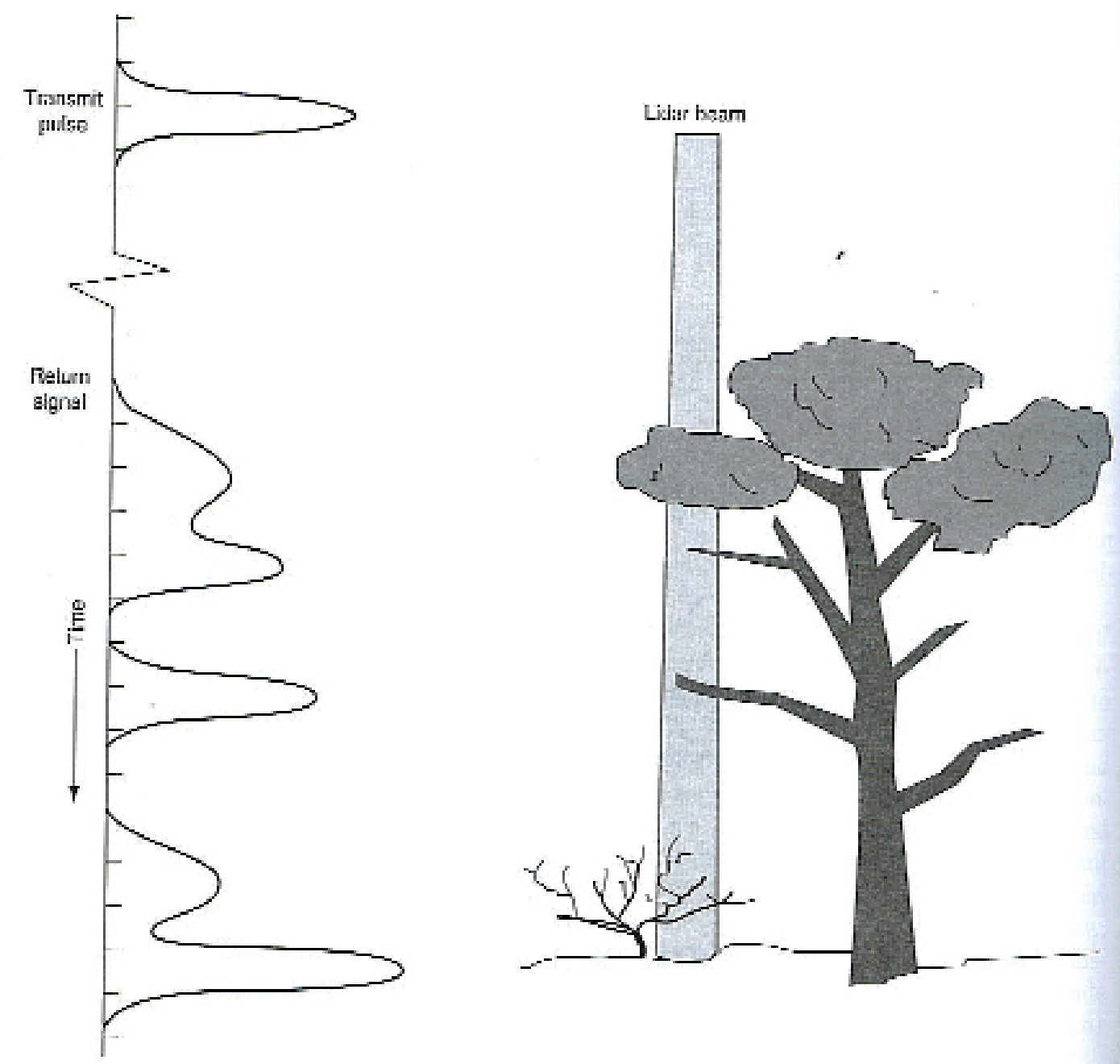

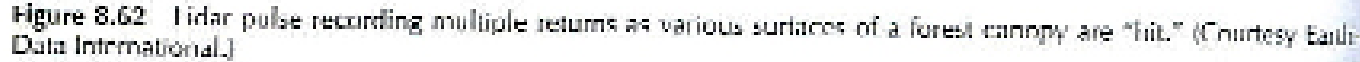

Figure 3: Diagram showing the multiple returns and the various intensities of the reflected waveforms from the emitted pulses of light during LiDAR data acquisition. Diagram taken from Lillesand, Kiefer, and Chipman, 2004. 
The errors associated with LiDAR data are inherent errors of the equipment and human error resulting from interpretation. The positional errors in LiDAR data collection are associated with the GPS equipped on the aircraft, the inertial navigation unit, used for estimating points between GPS corrections, and the IMU used for measuring the direction of the laser (Hodgson and Bresnahan, 2004). Human error is introduced if an automated intensity filter is not used and interpretation of the waveform returns is required. However, even despite the inherent errors associated with the data acquisition, LiDAR data can be extremely accurate, both horizontally and vertically. Many LiDARderived DEM's have been recorded as having vertical accuracies of $26 \mathrm{~cm}$ to $153 \mathrm{~cm}$ (Hodgson and Bresnahan, 2004). These highly accurate results provide an invaluable tool for research in numerous fields such as geology, geomorphology, forestry, ecology, and geography. 